MARIA FERNANDA CARRIEL AMARY

\title{
Detecção da fusão SS18-SSX em material parafinado e comparação de métodos moleculares como ferramentas no diagnóstico do Sarcoma Sinovial
}

Tese apresentada à Faculdade de Medicina da Universidade de São Paulo para obtenção do título de Doutor em Ciências.

Área de Concentração: Patologia

Orientadora: Profa. Dra. Fabíola Del Carlo Bernardi

São Paulo 
A Maria Regina,minha mãe, pelo amor e apoio incondicionais.

A Jorge, meu pai e professor, razão da minha escolha profissional, minha grande inspiração e exemplo.

A Jorge, Ricardo e Marília, meus irmãos, pela presença marcante e apoio em todos os momentos. 


\section{Agradecimentos}

À minha orientadora, Profa. Dra. Fabíola Del Carlo Bernardi, professora e amiga. Agradeço o seu apoio, cuidado, orientação em todos os aspectos, incentivo, exemplo profissional, ético e humano.

À Profa. Dra. Adrienne M. Flanagan, orientadora do estágio no exterior, agradeço pela orientação, exemplo, ensinamentos e pela possibilidade da realização dos métodos moleculares.

À Profa. Dra. Carmen Lucia Penteado Lancellotti, professora e amiga, incentivadora em todos os momentos.

À Dra Marilia Germanos de Castro, companheira em todos os momentos, pelo apoio incondicional.

Ao Prof. Dr. José Donato de Próspero, grande didata, exemplo profissional, agradeço a formação constante em patologia.

Ao Prof. Dr. Dino Martini Filho, chefe do Serviço de Anatomia Patológica, pelo apoio e incentivo constantes.

Ao Prof. Dr. Roberto Antonio Pinto Paes, pelo apoio e influência na obtenção do estágio na Inglaterra.

Às Doutoras Helena Muller e Maria Antonieta Longo Galvão, companheiras de todos os plantões, pela compreensão e apoio.

Aos colegas e funcionários do Departamento de Patologia, companheiros na convivência diária, agradeço o apoio em todos os momentos. 
Aos colegas e funcionários do University College London e Royal National Orthopaedic Hospital, pelo apoio e ensinamentos na área molecular.

Ao Prof. Dr. Pedro Péricles Ribeiro Baptista e ao Dr Eduardo Sadao pelo apoio e ensinamentos na área de Oncologia Ortopédica.

À Sra. Ana Paula Scramin pela colaboração nas análises estatísticas.

À minha tia, Profa Violette Nagib Amary, pela revisão do texto.

Aos residentes da Anatomia Patológica e aos alunos da Faculdade de Ciências Médicas da Santa Casa de São Paulo (FCMSCSP), cuja existência fundamenta todo este trabalho.

A todos os meus professores da FCMSCSP que, com seu exemplo de dedicação e amor à profissão, me estimularam a seguir tal carreira.

À pós-graduação da Universidade de São Paulo pela oportunidade e confiança.

À Coordenação de Aperfeiçoamento de Pessoal de Nível Superior (CAPES) e à FCMSCSP pelo auxílio financeiro.

A todos que colaboraram para a realização deste trabalho. 


\section{Sumário}

Lista de Abreviaturas

Resumo

Summary

1. Introdução / Revisão da Literatura .................................................. 1

1.1 Relevância clínica ................................................................... 1

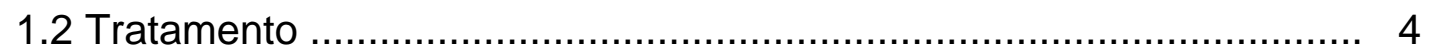

1.3. Caracterização Morfológica - Fatores Prognósticos ...................... 5

1.4. Caracterização Citogenética e Molecular ...................................... 14

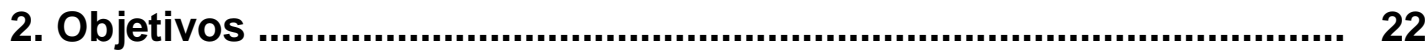

3. Métodos [........................................................................................... 23

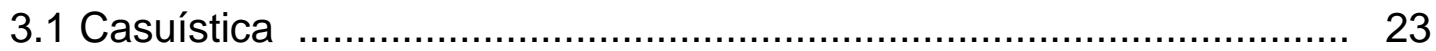

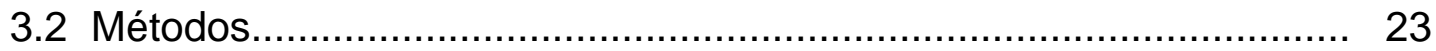

3.2.1 Caracterização Morfológica............................................... 24

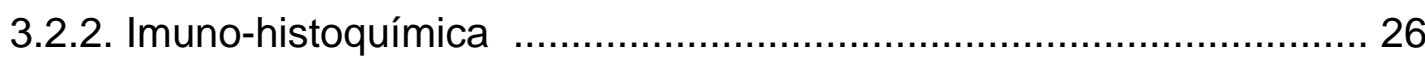

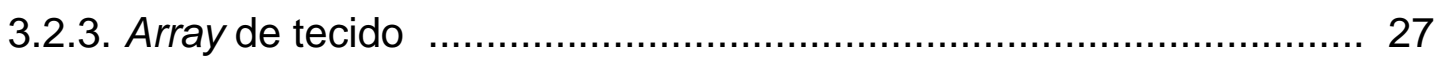

3.2.4. Extração do RNA .................................................................... 29

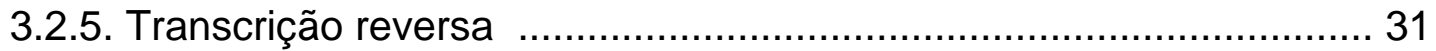

3.2.6. Reação de cadeia em polimerase quantitativa (qPCR) ................. 32

3.2.7. Reação de Cadeia em Polimerase Convencional .......................... 34

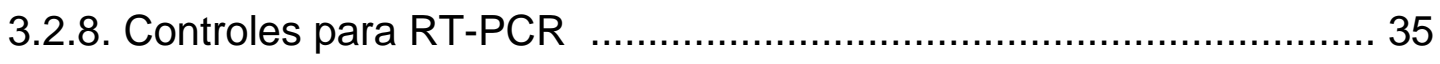


3.2.9. Hibridização in situ por fluorescência (FISH)

4. Resultados

4.1 Características clínicas e histológicas 38

4.1.1. Subtipo histológico 40

4.1.2. Índice mitótico 41

4.1.3. Resultados imuno-histoquímicos 42

4.2. Resultados quanto à detecção da fusão SS18-SSX 45

4.3. Resultados quanto ao tipo de fusão SS18-SSX ........................ 46

4.4. Análise estatística quanto ao tipo de fusão SS18-SSX .................. 47

4.5. Resultados dos casos utilizados como controle negativo ................. 50

4.6. Resultados quanto à detecção de rearranjo de SS18 por FISH .......... 52

5. Discussão

6. Conclusões

7. Anexos

8. Referências 79

9. Apêndices (Publicações). 91 


\section{Lista de Abreviaturas, siglas e símbolos}

$\mu \mathrm{l} \quad$ microlitro

BI Bifásico

cDNA Ácido Desoxirribonucléico, fita complementar

CGA Campo de grande aumento

CK citoqueratina

cm centímetro

DNA Ácido Desoxirribonucléico

EMA antígeno epitelial de membrana

FNCLCC Fédération Nationale des Centres de Lutte Contre le Cancer

FISH Hibridização in situ por fluorescência

G6PD Glicose-6-fosfato desidrogenase

HE hematoxilina \& eosina

IH imuno-histoquímica

ISH Hibridização in situ

mg miligrama

ml mililitro

MP Monofásico Fibroso

n número de casos

OMS Organização Mundial da Saúde

p braço curto do cromossomo

PD Pouco Diferenciado

PNET Tumor Neuroectodérmico Primitivo 
q braço longo do cromossomo

RNA Ácido Ribonucléico

RT-PCR Reação em Cadeia de Polimerase, transcriptade reversa

qRT-PCR quantitativo (técnica de Real time)

SS Sarcoma Sinovial

t translocação

TMBNP Tumor maligno da bainha do nervo periférico

$x^{2} \quad$ qui quadrado 


\section{Resumo}

Amary, MFC. Detecção da fusão SS18-SSX em material parafinado e comparação de métodos moleculares como ferramentas no diagnóstico do Sarcoma Sinovial [tese]. São Paulo: Faculdade de Medicina, Universidade de São Paulo; 2007. 100p.

O Sarcoma Sinovial revela consistentemente $t(X ; 18)$ resultando em SS18SSX1, SS18-SSX2 e raramente SS18-SSX4. Dos 328 casos incluídos neste estudo, Sarcoma Sinovial foi considerado a primeira possibilidade diagnóstica ou um importante diagnóstico diferencial em 134 casos: destes, cDNA de qualidade foi obtido em 131. A fusão SS18-SSX foi identificada em 126 (96\%) casos (74 SS18-SSX1, 52 SS18-SSX2) através de qRT-PCR e 120 (92\%) por RT-PCR convencional. 101 casos no array de tecidos, analisados por FISH, revelaram que 87 (86\%) mostraram rearranjo do SS18. Quatro casos positivos por RT-PCR mostraram perda de um sinal spectrum green e 15 casos revelaram cópias múltiplas de SS18: ambos os achados são potencialmente problemáticos na interpretação de resultados. Um dos 3 casos não analisados por RT-PCR por não ter gerado cDNA de qualidade, foi positivo por FISH. A fusão SS18-SSX1 foi demonstrada em 56 SS monofásicos e 18 SS bifásicos. SS18-SSX2 foi detectada em 41 monofásicos e 11 bifásicos. Áreas pouco diferenciadas foram identificadas em 44 casos (31\%). Não houve correlação estatisticamente significante entre os subtipos bifásico, monofásico e o tipo de fusão. Cinco casos foram negativos através dos três métodos utilizados, três de localização pleural. Após correlação clínica, o diagnóstico de mesotelioma foi favorecido em um caso, tumor fibroso solitário em outro e o diagnóstico de sarcoma sem outras especificações no terceiro. A possibilidade do diagnóstico de TMBNP não pode ser excluída nos outros dois casos. Nós concluímos que os métodos moleculares são ferramentas auxiliares importantes para o diagnóstico de SS com 95\% de sensibilidade e 100\% de especificidade, mas os resultados devem ser interpretados à luz de características clínicas e dados imunohistoquímicos. 


\section{Summary}

Amary, MFC. Detection of SS18-SSX fusion transcripts in Formalin-Fixed Paraffin-Embedded tissue and comparison of molecular methods as diagnostic tools for Synovial Sarcoma [thesis]. São Paulo: "Faculdade de Medicina da Universidade de São Paulo"; 2007. 100p

Synovial Sarcoma consistently harbors $t(X ; 18)$ resulting in SS18-SSX1, SS18-SSX2 and rarely SS18-SSX4 fusion transcripts. Of 328 cases included in our study, synovial sarcoma was either the primary diagnosis or was very high in the differential diagnosis in 134 cases: of these, amplifiable cDNA was obtained from 131. SS18-SSX fusion products were found in 126 (96\%) cases, (74 SS18-SSX1, 52 SS18-SSX2), using quantitative and 120 by conventional RT-PCR. 101 cases in a tissue microarray, analyzed by FISH, revealed that 87 (86\%) showed SS18 rearrangement: 4 reverse transcriptase -polymerase chain reaction positive cases, reported as negative for $\mathrm{FISH}$, showed loss of one spectrum green signal, and 15 cases had multiple copies of the SS18 gene: both findings are potentially problematic when interpreting results. One of 3 cases, not analyzed by RT -PCR due to poor quality RNA, was positive by FISH. SS18-SSX1 was present in 56 monophasic and 18 biphasic synovial sarcoma: SS18-SSX2 was detected in 41 monophasic and 11 biphasic synovial sarcoma. Poorly differentiated areas were identified in 44 cases (31\%). There was no statistically significant association between biphasic, monophasic and fusion type. Five cases were negative for SS18 rearrangement by all methods, 3 of which were pleural-sited neoplasms. Following clinical input, a diagnosis of mesothelioma was favored in one case, a sarcoma, not-otherwise specified in another and a solitary fibrous tumor in the third case. The possibility of a malignant peripheral nerve sheath tumor could not be excluded in the other 2 cases. We concluded that the employment of a combination of molecular approaches is a powerful aid to diagnosing synovial sarcoma giving at least 96\% sensitivity and $100 \%$ specificity but results must be interpreted in the light of other modalities such as clinical findings and immunohistochemical data. 


\section{Introdução / Revisão da Literatura}

\subsection{Relevância Clínica}

O Sarcoma Sinovial (SS) é uma neoplasia que acomete, principalmente, as regiões para-articulares das extremidades nas proximidades de grandes articulações (1-5). Outras localizações menos freqüentes como cabeça e pescoço, cavidade pleural, coração, parede ou intra-abdominal, intravascular e intra-ósseo são descritas (6-11). Sua incidência varia na literatura, de $5,6 \%$ a $14 \%$ entre os sarcomas de tecidos moles (12;13). É mais prevalente em adolescentes e adultos jovens, entre 15 e 40 anos de idade. Os homens são pouco mais acometidos que as mulheres, em razão de 1,2:1. Não há evidências de predileção por raça $(12 ; 14)$.

A identificação desta neoplasia e a sua semelhança com o tecido sinovial normal foram reconhecidas há muito tempo na literatura, mas sua origem a partir de tecido sinovial nunca foi comprovada. A primeira descrição de Sarcoma Sinovial foi atribuída a Simon em 1865, apud Fisher (1998) (6), que relatou um tumor pedunculado, envolvendo o joelho direito de um homem de 46 anos. A descrição convincente mais antiga na literatura, porém, data de 1910. Seus autores, Lejars e Rubens-Duval, apud Fisher (1998) (6), realizaram um desenho do componente bifásico, comentando a possível combinação entre uma neoplasia epitelial e outra de tecido conectivo, denominando-a Endotelioma sinovial. Em 1927, Smith, apud Knox 
(1936) (15), nomeou esta neoplasia como Sinovioma, apontando que a origem não era exclusivamente em articulações mas também em tendões, fáscias e aponeuroses. O termo Sarcoma Sinovial foi introduzido por Knox em 1936. Anteriormente, no final do Século XIX, estes tumores eram chamados de adenosarcoma, sarcoendotelioma sinovial, sarcomesotelioma e mesotelioma de articulações.

A apresentação clínica mais freqüente é a presença de um tumor profundo, indolor ou doloroso. A duração dos sintomas varia muito. Geralmente, o tumor cresce lenta e insidiosamente, dando a falsa impressão de baixo grau de malignidade, e por isso, retardando o diagnóstico e o tratamento. Na maioria dos casos o tempo de história até o diagnóstico é de dois a quatro anos, mas existem casos de crescimento mais lento ou de dor incaracterística no sítio do tumor, que foram notadas por longos períodos de tempo, com relatos de até 25 anos (1-3;16).

Considerada previamente como neoplasia, exclusivamente, de alto grau e de mau prognóstico, tem despertado mais recentemente o interesse de pesquisadores preocupados com a melhora da sobrevida. As diferentes casuísticas (14;17-22) têm procurado identificar possíveis fatores de prognóstico que possam, eventualmente, orientar melhor as diversas modalidades de tratamento.

A dificuldade de estabelecer um critério de graduação não é exclusiva do Sarcoma Sinovial. Os sarcomas de tecidos moles representam um grupo heterogêneo e relativamente raro de tumores malignos, com grande variedade de tipos histológicos e de prognósticos. Vários sistemas de estadiamento e graduação foram, e vêm sendo criados, na tentativa de 
correlacionar parâmetros clínicos e histológicos com o prognóstico, definindo um tratamento ideal para cada paciente. Existe um consenso na literatura, que o fator mais importante para previsão de sobrevida e desenvolvimento de metástases à distância, é a graduação histológica $(23 ; 24)$. A relativa raridade dos sarcomas e a complexidade de tipos histológicos, no entanto, freqüentemente dificulta a determinação precisa do grau histológico de malignidade, mesmo entre os profissionais mais experientes e especializados nesta área da patologia (13).

A evolução e o prognóstico dos casos de Sarcoma Sinovial depende, como em outras neoplasias, de características do paciente, do tumor e do tratamento realizado. A porcentagem de sobrevida em cinco anos, reportada na literatura, varia de 36 a 76\%, chegando a $82 \%$ em casos densamente calcificados. Já a sobrevida em dez anos varia de 20 a 63\% (1;2;16;25-27).

Os índices de recidiva local, após tratamento cirúrgico adequado ou com radioterapia adjuvante quando necessário, estão em torno de 28 a 36\%. Lesões metastáticas ocorrem em aproximadamente metade dos casos, muitas delas aparecendo vários anos após o diagnóstico inicial. O principal sítio de metástase é o pulmão, seguido de linfonodos e do osso $(12 ; 14 ; 16 ; 28 ; 29)$. 


\subsection{Tratamento}

Existe um consenso na literatura que o tratamento deste grupo de sarcomas é primariamente cirúrgico, sendo que a extensão das margens cirúrgicas tem relação direta com o controle local da doença. A presença de margens cirúrgicas amplas e livres de neoplasia é estatisticamente representativa como fator de prognóstico. A melhor sobrevida também é alcançada quando os sarcomas são tratados em instituições especializadas e habituadas ao tratamento deste tipo de lesão (2;26;30). O uso da radioterapia é indicado por alguns autores como tratamento adjuvante no controle local da doença (31) e parece ter efeito significativamente benéfico nos casos tratados com ressecção marginal. Já, nos casos tratados com margens amplas ou ressecção radical, não houve diferenças quanto à recidiva, através da adição da radioterapia como método terapêutico (32-34).

A efetividade de quimioterapia adjuvante no tratamento do Sarcoma Sinovial é controversa, sendo utilizada principalmente nos casos do grupo pediátrico (30). Ladenstein et al. em 1993, estudando 31 pacientes do grupo pediátrico, tratados com quimioterapia associada ou não à exérese cirúrgica, encontraram maior porcentagem de sobrevida em cinco anos, quando comparativamente a outros trabalhos na literatura, o que, segundo os autores, indicaria um efeito benéfico do tratamento (31). Rosen et al. em 1994, advogaram que o tratamento quimioterápico com altas doses de ifosfamida é benéfico e surpreendente em casos avançados, com resposta importante nas metástases (35). O trabalho recente de Spurrell et al., baseado na análise de 104 casos avançados de Sarcoma Sinovial aponta 
para melhor sobrevida na utilização da combinação de doxorrubicina e ifosfamida como adjuvantes no tratamento do SS (36).

A presença de metástases pulmonares é considerada um evento préterminal em pacientes portadores de sarcomas. O índice de sobrevida é menos favorável nos casos que desenvolveram metástases; a excisão da metástase pulmonar, entretanto, parece ter um grande impacto na sobrevida deste grupo de pacientes (25).

\subsection{Caracterização Morfológica - Fatores Prognósticos}

Classificado como tumor do tecido sinovial na primeira edição da Classificação da OMS, em 1969, teve sua relação com o tecido sinovial normal reconhecida durante muito tempo, que favoreceu sua origem a partir deste tecido (37;38). Na edição de 1994 desta classificação, aparece no grupo "miscelânea"(39). Na edição de 2002, está classificado no grupo de tumores de origem incerta (40). Os sinoviocitos normais reagem somente com anticorpo anti-vimentina e não reagem com anti-CK; não apresentam

microvilosidades, junções complexas, estruturas semelhantes a desmossomos ou a lâmina basal à microscopia eletrônica. Tais dados, que contrariam a origem desta neoplasia a partir de células sinoviais, surgiram em bases imuno-histoquímicas e ultra-estruturais. A linha exata de diferenciação do Sarcoma Sinovial ainda permanece indeterminada (41-47). 
Esta neoplasia exibe ampla gama de aspectos histológicos. Seu diagnóstico tem sido aventado com o reconhecimento dos seus subtipos histológicos e, cada vez mais, fundamentado através de métodos imunohistoquímicos e/ou citogenéticos complementares. Atualmente vem sendo considerado como o quarto tipo mais freqüente de sarcoma (5).

São reconhecidos os seguintes subtipos histológicos: bifásico, monofásico e pouco diferenciado (14;22;43;48-52). Os tipos bifásico e monofásico fibroso são os mais freqüentes. O pouco diferenciado faz diagnóstico diferencial com grande número de tumores $(5 ; 52)$. O tipo clássico é o bifásico, com células epiteliais semelhantes a carcinoma, e outras fusiformes. Dependendo da predominância celular e do grau de diferenciação, o Sarcoma Sinovial forma um espectro morfológico entre os subtipos supracitados $(5 ; 12)$.

O componente fusocelular é constituído por células curtas e alongadas, com escasso citoplasma e pouco ou nenhum pleomorfismo. A arquitetura celular é predominantemente formada por pequenos feixes compactos, sem o padrão em "espinha de peixe" do Fibrossarcoma. Há pouco estroma entre as células, mas pode haver abundante colágeno, por vezes hialinizado ou similar a osteóide (pseudo-osteóide). Entremeando as células fusiformes, no tipo monofásico fibroso, podem-se identificar células arredondadas que perdem muito de suas características fusiformes originais e, por vezes, assumem aspecto epitelióide (12;14). 
O componente epitelial é, geralmente, menos proeminente, podendo assumir diversos arranjos - agrupamentos, ilhotas, blocos, estruturas glandulares ou, delimitando espaços em fendas. As células são arredondadas com citoplasmas demarcados, núcleos vesiculosos e com nucléolos evidentes (12;14).

Alguns Sarcomas Sinoviais podem exibir componente pouco diferenciado em focos ou extensas áreas. Tal componente foi, inicialmente, descrito como de células pequenas, redondas e hipercromáticas, em mantos, semelhantes ao Tumor Neuroectodérmico Primitivo (PNET) e ao Sarcoma de Ewing. Além do padrão pouco diferenciado de células pequenas, mais dois padrões são reconhecidos. Um deles é caracterizado como variante de células grandes atípicas, com elevada celularidade e pleomorfismo significante, citoplasma mais amplo e citologia intermediária entre células fusiformes e epiteliais. O outro padrão pouco diferenciado exibe células fusiformes no subtipo monofásico fibroso clássico, mas com elevado índice mitótico, com extensas áreas de necrose e padrão em "espinha de peixe", como no Fibrossarcoma de alto grau $(30 ; 50 ; 52)$.

As células do Sarcoma Sinovial podem secretar dois tipos de material mucinoso. O primeiro, nos espaços pseudo-glandulares, que se cora positivamente pelo Ácido Periódico de Schiff (PAS), ferro coloidal, azul alciano e mucicarmim. O segundo, mucina estromal ou mesenquimal, que é elaborada pelas células fusiformes, e também se cora positivamente para ferro coloidal e azul alciano, mas é PAS negativo (5;43;53). 
Quanto ao valor do subtipo histológico como fator de prognóstico, alguns autores $(17 ; 54)$ advogaram pior prognóstico para o subtipo Monofásico Fibroso, quando comparado ao Bifásico. Entretanto, outros autores $(16 ; 37 ; 54 ; 55)$ não apontaram diferenças entre os subtipos Monofásico ou Bifásico quanto ao prognóstico.

A partir da identificação do subtipo Pouco Diferenciado, os autores (16;50;56;57) têm concordado em afirmar que este subtipo está associado a pior prognóstico. Assim, Machen et al. em 1999 apontaram pior prognóstico naqueles casos que exibiam aspecto pouco diferenciado em mais de $20 \%$ da área tumoral (49).

A presença de necrose e de alto índice mitótico está relacionada com pior evolução e baixa sobrevida $(17 ; 19 ; 49 ; 58)$. Outro fator que, mais freqüentemente, em numerosas séries, é relacionado ao pior prognóstico é o maior tamanho do tumor $(14 ; 21 ; 22 ; 28 ; 49 ; 54 ; 59-63)$.

Outros fatores como: idade, localização proximal, índice mitótico, índice de proliferação celular - Ki-67, imuno-expressão de $H E R 2 / n e u$, alto grau nuclear, necrose tumoral, células rabdóides, número de mastócitos, invasão óssea e estadiamento, foram apontados como fatores de prognóstico (49;64-68).

Apesar do clássico consenso em se considerar o Sarcoma Sinovial uma neoplasia de alto grau de malignidade, algumas tentativas de 
separação e agrupamento dos casos em relação ao prognóstico vêm sendo desenvolvidas. Cagle et al. em 1987, dividiram os Sarcomas Sinoviais em dois grupos: de alto e de baixo risco, baseando-se nos valores de corte 50\% de área neoplásica formando glândulas; 15 figuras de mitose/dez CGA. Com acompanhamento médio de 41 meses, a sobrevida entre os grupos variou de $37 \%$ nos de alto risco a $100 \%$ nos casos de baixo risco (17).

Também buscando a separação em dois grupos, de alto e de baixo risco, Bergh et al., em 1999, estudaram dados clínicos e histológicos de 121 pacientes e concluíram que o fator de maior importância prognóstica foi a morfologia pouco diferenciada (16).

O Grupo Escandinavo de Sarcoma (22) separou os casos de Sarcoma Sinovial em dois subgrupos, histologia favorável ou histologia desfavorável, usando critérios puramente histológicos. O primeiro seria representado por tumores grau III nos sistemas de graduação convencionais propostos por Broders em 1939 (69); isto é, lesões sem atipias significativas e na maioria das vezes sem necrose e com contagem mitótica menor que dez mitoses / dez campos de grande aumento. O grupo de histologia desfavorável incluiria os tumores grau IV, representados pelos chamados Sarcomas Sinoviais pouco diferenciados e pelos subtipos bifásico e monofásico com atipias nucleares proeminentes, além de alta celularidade com aglomerados nucleares, necrose e contagem mitótica acima de dez mitoses/dez campos de grande aumento. Essa designação, segundo os autores, tem maior significância prognóstica que qualquer um dos fatores histológicos estudados isoladamente. A sobrevida sem metástases no 
primeiro grupo, em cinco anos, foi de $83 \%$ comparada com $31 \%$ no segundo grupo designado como de histologia desfavorável (22).

Baptista et al., em no nosso meio, graduaram os casos de Sarcoma Sinovial em baixo e alto grau, encontrando correlação estatística com a sobrevida. Foram considerados como alto grau os casos que apresentassem, necessariamente, índice de atividade mitótica maior ou igual a cinco / dez CGA, necrose acima de $25 \%$ e grau de "glandularidade" abaixo de 50\%. Segundo o autor, este foi o fator histológico de maior significância prognóstica (70).

O estudo imuno-histoquímico dos componentes epitelial e fusiforme revela positividade para anticorpos anti-citoqueratina de alto e baixo pesos, e/ou antígeno epitelial de membrana (EMA), em todos os tumores do tipo bifásico e, em grande parte, dos monofásicos fibrosos.

Em 1984, Corson et al. detectaram imuno-expressão focal de anticorpos anti-citoqueratinas em $50 \%$ dos casos do subtipo Monofásico Fibroso e, também, no componente de células fusiformes do subtipo bifásico (71).

O anticorpo anti-citoqueratina (CK) é detectado nas áreas glandulares do subtipo bifásico e em células individuais, em cordões celulares ou em pequenos agrupamentos no subtipo Monofásico.

A expressão do anticorpo anti-EMA ocorre nos Sarcomas Sinoviais com freqüência similar ou até mais alta que as citoqueratinas (72). No subtipo bifásico, nas estruturas glandulares, a positividade é mais intensa na superfície do lúmen (58). 
Os trabalhos iniciais, em geral, apontaram maior freqüência de positividade de citoqueratina em relação ao EMA. Contrariamente, o estudo de Folpe et al. em 1998 e o de van de Rijn et al. em 1999, realizados em casos do subtipo pouco diferenciado, revelaram $100 \%$ e $95 \%$ de positividade para o EMA e; $66,6 \%$ e $40 \%$ de reatividade para citoqueratinas, respectivamente $(48 ; 52)$. Nossa experiência revela maior positividade para o EMA (100\%) em relação às citoqueratinas (81\%) na casuística inicial de 32 Sarcomas Sinoviais estudados (73).

O uso de CK 7 e de outras citoqueratinas vem sendo incentivado para o diagnóstico diferencial entre os dois subtipos: monofásico e pouco diferenciado, de um lado e, os tumores neuroectodérmicos: Tumor Maligno da Bainha do Nervo Periférico (TMBNP) e PNET do outro. Os trabalhos $(48 ; 74 ; 75)$ apontaram predominância de imuno-expressão de CK 7 e de CK 19 nos Sarcomas Sinoviais, sendo negativos na maioria dos casos de PNET ou de TMBNP.

A imuno-expressão de proteína S-100 nos Sarcomas Sinoviais varia na literatura, chegando até 63\% (52).

A ausência de áreas típicas no subtipo pouco diferenciado pode prejudicar bastante o diagnóstico, pois estas neoplasias compartilham características histológicas e imuno-histoquímicas como CD99, Calponina, proteína S-100 e CK com outros tumores como o PNET, o TMBNP e o Sarcoma de Ewing $(48 ; 52 ; 56 ; 76)$.

Quanto à análise da expressão imuno-histoquímica do bcl-2 em Sarcoma Sinovial, os diversos estudos (73;77-79) passaram a associá-la 
não com o prognóstico, mas como técnica adjuvante no diagnóstico deste tipo particular de Sarcoma.

Em 1996, Hirakawa et al., encontraram imuno-expressão da proteína bcl-2 em 15 de 19 casos de Sarcoma Sinovial, sem correlação estatística com baixa sobrevida. Os outros sarcomas analisados neste estudo, incluindo 20 Leiomiossarcomas, quatro TMBNP e quatro Fibrossarcomas, foram todos negativos para este marcador (80).

Suster et al. em 1998, sugeriram a utilização dos anticorpos antiproteína $b c /-2$ e anti-CD34, combinados como parte de um painel para o diagnóstico diferencial entre os Sarcomas de células fusiformes (81). Neste estudo, os autores encontraram positividade para proteína bcl-2 e negatividade para CD-34 em todos os casos de Sarcoma Sinovial. Estudando outros tumores fusocelulares, os autores não encontraram forte imuno-marcação para a proteína $b c l-2$ em nenhum tipo de sarcoma que participa do diagnóstico diferencial com esta neoplasia. Concluíram que o marcador pode ser extremamente útil no diagnóstico de Sarcoma Sinovial, especialmente nos casos com pouca ou nenhuma imuno-expressão de marcadores epiteliais (80-83).

A combinação da imunorreatividade para CK, EMA, bcl-2, com ausência de marcação para CD34 é importante ferramenta diagnóstica para os casos de Sarcoma Sinovial monofásico fibroso e pouco diferenciado $(73 ; 84)$

Trabalhos que analisaram o p53 como fator prognóstico, englobaram séries de diversos tipos histológicos de sarcoma, e não um grupo de tumores do mesmo tipo $(30 ; 85-87)$. 
A experiência do Grupo Escandinavo de Sarcoma em 86 pacientes com Sarcoma Sinovial primário, mostrou que a expressão imunohistoquímica da proteína p53 não apresentou correlação estatisticamente significante em relação ao prognóstico (57). O estudo de ODA et al. em 2000 corroborou este resultado (88).

Antonescu et al. em 2000, relacionaram a imuno-expressão da proteína p53 e o alto índice proliferativo Ki67, como fatores implicantes em pior prognóstico (89).

Quanto ao aspecto ultra-estrutural, as células epiteliais apresentam núcleos ovóides, abundante citoplasma contendo mitocôndrias, complexo de Golgi proeminente, lisossomos, raros agregados paranucleares de filamentos intermediários e retículo endoplasmático liso e rugoso. Estas células são poligonais ou cilíndricas, dispostas em agregados ou formando estruturas glandulares, com microvilosidades na superfície intercelular ou na face da célula voltada para a luz pseudoglandular. A luz glandular pode conter material amorfo, mas não foi encontrada mucina intracelular. Estas células são conectadas por junções complexas, zona aderente ou estruturas semelhantes a desmossomos. Os agregados de células epiteliais estão separados do componente fusocelular por lâmina basal $(5 ; 41 ; 43)$.

O componente de células fusiformes do Sarcoma Sinovial bifásico e o monofásico fibroso são semelhantes sob o aspecto ultra-estrutural $(5 ; 43)$. As áreas fusocelulares estão entremeadas por substância amorfa e fibras colágenas. Processos citoplasmáticos e, ocasionalmente, microvilosidades são encontrados em espaços intercelulares ou em fendas de vários 
tamanhos. Junções e estruturas semelhantes aos desmossomos podem ser encontradas entre as células que estão ou não margeando os espaços intercelulares. Muitas células nas áreas fusocelulares, na avaliação ultraestrutural, são arredondadas ou poligonais, lembrando as células epiteliais do componente bifásico e correspondendo aos tipos celulares intermediários que podem ser identificados na microscopia óptica. Podem-se identificar também nestas áreas, agregados celulares entremeados por fragmentos de lâmina basal $(5 ; 41 ; 90)$.

A característica ultra-estrutural essencial para o diagnóstico de Sarcoma Sinovial é, certamente, a presença de diferenciação epitelial, reconhecida como: espaços intercelulares contendo processos citoplasmáticos, presença de junções intercelulares e grupos de células envoltos por lâmina basal no componente bifásico (41).

\subsection{Caracterização Citogenética e Molecular}

Entre os sarcomas de células fusiformes, o Sarcoma Sinovial representa um dos raros tumores com alteração genética adquirida característica (91). A maioria dos sarcomas fusocelulares compartilha a tendência para a complexidade de alterações do cariótipo com os sarcomas pleomórficos (92).

A análise citogenética revela de forma consistente a translocação recíproca entre os cromossomos X e $18 \mathrm{t}(\mathrm{X} ; 18)(\mathrm{p} 11.2 ; q 11.2)$ (93-95), que 
resulta em genes quiméricos intimamente relacionados: SS18-SSX1; SS18SSX2 e, raramente SS18-SSX4. O ponto de quebra que dá origem à translocação, geralmente está em seqüências intrônicas, tanto no gene SS18 (também conhecido como SYT) como nos genes SSX envolvidos (91). Na grande maioria dos SS a fusão de SS18 com SSX1 ou SSX2 envolve as mesmas áreas exônicas. O exon 10 em SS18 funde-se com o exon 6 em ambos SSX1 e SSX2. Variantes de fusão são raras e são descritas em casos isolados. (Figura 1) (96-109).

A estrutura da família SSX de genes é muito similar. Existe mais de $75 \%$ de homologia entre SSX1 e SSX2, sendo a maior diferença no exon 5 $(102 ; 110 ; 111)$. Foram identificados até agora nove genes da família SSX, todos localizados no cromossomo $X$, que apresentam 73 a $93 \%$ de homologia na seqüência de aminoácidos e 88 a 96\% de homologia nas sequências gênicas (111).

A porção protéica determinada por SS18 parece agir como um fator de transcrição, enquanto o SSX como um repressor da transcrição (112). Mas a proteína codificada tanto por SS18 como SSX não possui um fator ligante de DNA; sua ação, portanto, provavelmente ocorre através de interações proteína-proteína (112). Recentemente, a função da proteína SS18 foi relacionada à ativação de um co-ativador de receptor hormonal nuclear, também relacionado à regulação da transcrição (113). Os modelos de estudo da função da proteína quimérica SS18-SSX tentam estabelecer qual ação na transcrição seria dominante (114). A função da proteína quimérica SS18-SSX e sua relação com o desenvolvimento e progressão da 
neoplasia permanecem desconhecidas, assim como o mecanismo através do qual tal translocação ocorre (91).

Desde a identificação da translocação $t(X ; 18)$ dando origem à fusão SS18-SSX, diversos estudos tem sido publicados analisando vários aspectos de tal detecção.

Os primeiros trabalhos com material parafinado foram realizados por Nagao et al. em 1996, que revelando presença de marcações nucleares pelo método de FISH em 25 de 28 casos diagnosticados como Sarcoma Sinovial para detecção da translocação t(X;18)(115). Tsuji et al. em 1998, avaliaram 32 casos através do método de RT-PCR em material parafinado, detectando a fusão SS18-SSX em 30 casos (92\%) (116). Dos 23 casos monofásicos, 16 mostraram a fusão SS18-SSX1. Dos sete casos bifásicos, um revelou fusão SS18-SSX2, contrariando outros estudos que relacionavam este subtipo exclusivamente com a fusão SS18-SSX1 (117;118).

A maioria dos trabalhos com Sarcoma Sinovial, entretanto, tem utilizado material a fresco / congelado isoladamente ou em conjunto com material parafinado para o estudo citogenético ou molecular, com grande porcentagem de positividade nos diferentes métodos utilizados $(99 ; 102 ; 104 ; 107 ; 117-129)$ 


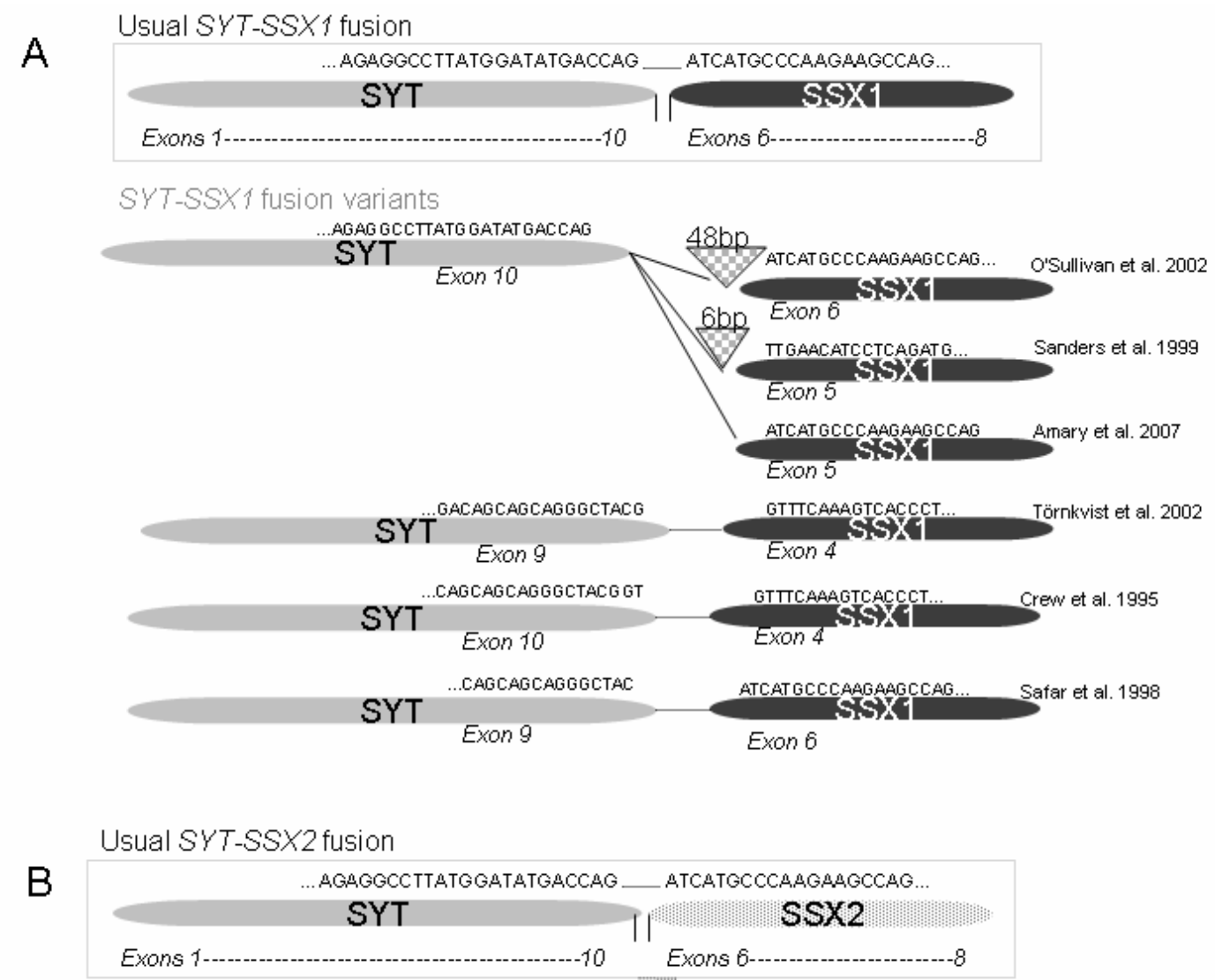

SYT-SSX2 fusion variants
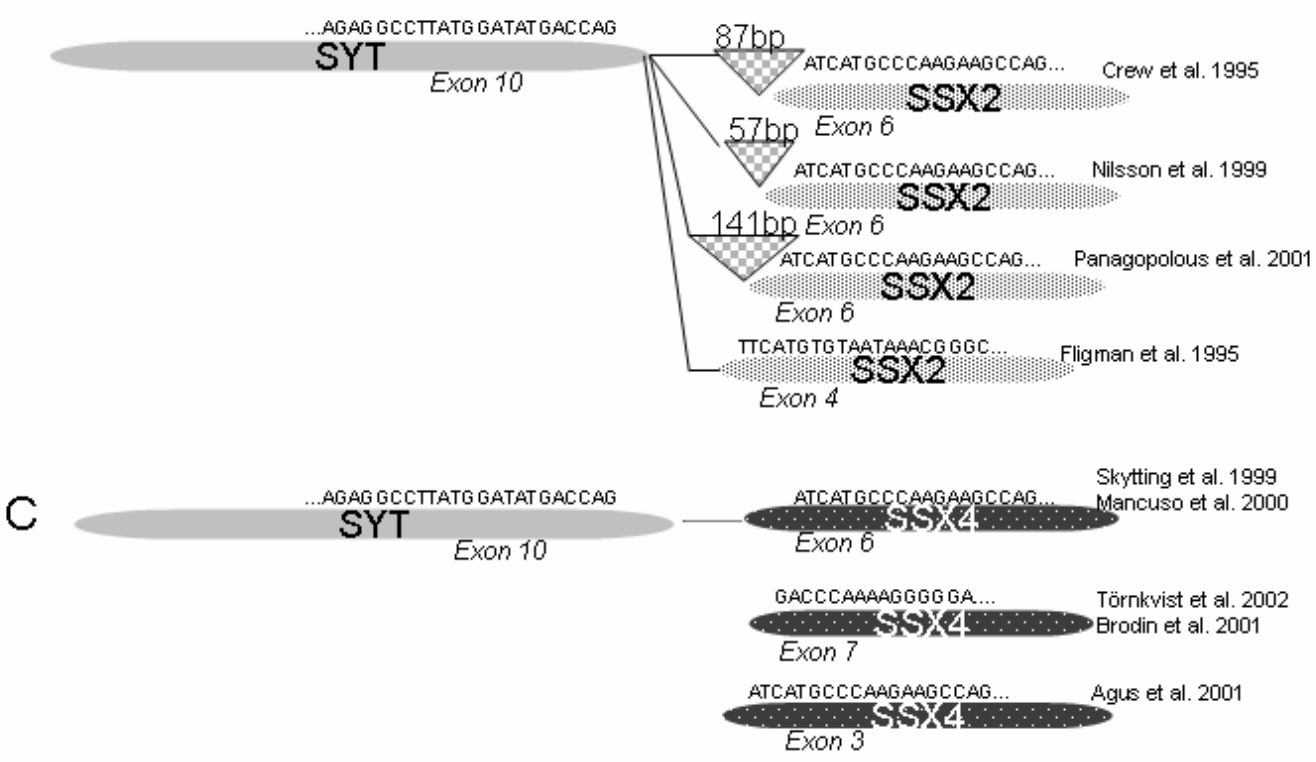

Figura 1. Diagrama representando os locais de fusão entre os genes SS18 e SSX1 (A), SSX2 (B) e SSX4 (C). As seqüências envolvidas na região exônica da fusão estão representados. 
Estudando a fusão entre os genes SS18 e SSX através da técnica de RT-PCR em 45 casos, Kawai et al. em 1998, detectaram melhor sobrevida sem metástases nos casos de fusão SS18-SSX2 (117). Os autores também relataram que todos os 12 casos bifásicos estudados mostraram a fusão SS18-SSX1.

Nilsson et al. em 1999, do Grupo Escandinavo de Sarcomas, estudaram o padrão de fusão SS18-SSX, comparando com a evolução e a porcentagem de positividade para o Ki-67 (102). Os autores concluíram ser significantemente menor a sobrevida em pacientes com imunomarcação para o anticorpo Ki-67 em 10\% ou mais das células neoplásicas. A sobrevida sem metástases em cinco anos foi de $42 \%$ em pacientes com fusão SS18SSX1 e de $89 \%$ em pacientes com fusão SS18-SSX2, detectadas por RTPCR. Houve também associação estatisticamente significante entre o tipo de fusão SS18-SSX1 e a positividade para Ki-67 acima de 10\%. Os autores relatam ainda que o padrão SS18-SSX2 foi exclusivo dos casos monofásicos e concluíram que a fusão SS18-SSX1 é relacionada ao pior prognóstico, apesar de julgarem necessário estudo maior, com análise multivariada.

Inagaki et al. em 2000, estudando 19 casos, demonstraram correlação entre o tipo de fusão SS18-SSX1, o alto índice mitótico e a maior imuno-expressão de Ki-67 (18). Não houve correlação entre o tipo de fusão SS18-SSX e a imuno-expressão de p53 e de bcl-2.

A necessidade de teste molecular em SS também foi abordada por Coindre et al. através de 204 amostras de tumores sucessivos que poderiam representar SS. A neoplasia foi classificada como "Provável" - quando o 
primeiro diagnóstico contemplado foi SS; "Possível" - quando SS não foi o primeiro diagnóstico contemplado. 87\% (177) dos casos apresentou RNA com qualidade suficiente para permitir investigação molecular. 54\% (104) dos casos foram positivos para SS18-SSX. Os autores concluem que o teste molecular é muito útil, principalmente quando SS não foi o principal diagnóstico contemplado (130).

Ladanyi et al, em um grande estudo multi-institucional retrospectivo de 243 pacientes com Sarcoma Sinovial, detectaram que a fusão SS18-SSX é o fator de prognóstico mais significante quando, no momento do diagnóstico, verifica-se que a doença está localizada (131). A sobrevida foi melhor em pacientes com a fusão SS18-SSX2. Detectaram também uma tendência para doença metastática nos pacientes com fusão SS18-SSX1. Neste estudo foram somente considerados dois subtipos histológicos: bifásico e monofásico. Os casos pouco diferenciados foram classificados como monofásicos(131).

Cento e sessenta e cinco portadores de Sarcoma Sinovial $t(X ; 18)$ positivo de instituições na França, Suíça e Bélgica foram estudados através da técnica de RT-PCR, seguida por enzimas de restrição para diferenciação entre os tipos de fusão SS18-SSX1 e SS18-SSX2 (132). Os autores não encontraram relação entre o tipo de fusão e pior prognóstico em ambas as análises: sobrevida sem doença e sobrevida sem metástases. Contrariando estudos anteriores, $(57 ; 117 ; 124 ; 131)$, a presença da fusão SS18-SSX2 mostrou tendência a comportamento biológico mais agressivo . Graduação 
histológica foi o fator independente de prognóstico neste estudo. Grau 3 (FNCLCC) (133) foi o fator mais importante relacionado à redução de sobrevida (132).

Apesar das exceções, o tipo bifásico exibe mais frequentemente a fusão SS18-SSX1, enquanto o monofásico parece envolver igualmente os genes SSX1 e SSX2 (134). Esta diferença mostrou-se estatisticamente significante $(P<0.001)$ na meta-análise realizada na literatura que incluiu um total de 1033 casos de SS, dos quais 314 foram classificados como bifásicos e somente em 42 destes foi detectada a fusão SS18-SSX2 (Anexo 1) $(99 ; 102 ; 104 ; 117 ; 118 ; 120 ; 121 ; 124 ; 125 ; 128 ; 134-143)$. Com isto, tem-se sugerido que a fusão SS18-SSX1 parece ser importante para a diferenciação epitelial (102). Raros casos individuais exibem a fusão SS18SSX4 (107).

Tem-se estudado o tipo de fusão na avaliação da natureza do Sarcoma Sinovial, em relação à clonalidade e à histogênese do tipo bifásico (144). A detecção da fusão dos genes SYS e SSX1 em ambos os componentes de 3 casos de Sarcoma Sinovial bifásico, segundo Birdsall et al. em 1999 e Kasai et al. em 2000, fornece evidência direta da origem clonal e da natureza verdadeiramente bifásica desta neoplasia, apontando para a possibilidade de diferenciação das células neoplásicas $(145 ; 146)$. Este fato é corroborado pelo encontro de formas celulares intermediárias entre epitelial e mesenquimal, através de estudos ultra-estruturais. 
Entre os fatores de prognóstico, observou-se em um estudo de 46 casos de Sarcoma Sinovial analisando a ploidia do DNA através da citometria de fluxo, que a sobrevida foi melhor em casos diplóides (147).

Independente da sua função ou significado prognóstico, a fusão SS18-SSX pode ter um papel terapêutico através do uso de alvos específicos em imunoterapia. O primeiro teste terapêutico esta em andamento e tem sido bem tolerado (148).

O "padrão ouro" para o diagnóstico do Sarcoma Sinoviai é conflitante na literatura. O encontro da $t(X ; 18)$ ou do seu produto (SS18-SSX) é o mais aceito por sua especificidade. O'Sullivan et al. em 2000, relataram a presença desta mesma alteração em casos de TMBNP, um dos principais diagnósticos diferenciais (149). Este trabalho foi duramente criticado na literatura e tal resultado não foi reproduzido (150).

A detecção da fusão SS18-SSX como "padrão ouro" permite a confirmação dos casos histologicamente diagnosticados como Sarcoma Sinovial para estudos subseqüentes e tratamento adequado. Esta detecção permite o diagnóstico de casos considerados como Neoplasias Indiferenciadas pelos métodos complementares de diagnóstico usualmente utilizados na rotina de patologia cirúrgica.

De forma adicional, a detecção molecular do tipo de fusão relacionase com o subtipo histológico, prognóstico e deve colaborar para a compreensão das vias oncogenéticas desta neoplasia de origem incerta. 


\section{Objetivos}

- Analisar a presença da fusão SS18-SSX em ampla série de lesões fixadas em formalina e incluídas em parafina;

- Comparar a eficácia de três métodos moleculares (RT-PCR convencional, qRT-PCR e FISH) na detecção desta fusão;

- Correlacionar o tipo de fusão SS18-SSX com o subtipo histológico, a localização e a presença de áreas pouco diferenciadas no Sarcoma Sinovial. 


\section{Métodos}

\subsection{Casuística}

Cento e trinta e quatro casos, sendo 76 ressecções e 58 biopsias, foram selecionados para o estudo. O material foi proveniente dos arquivos do Serviço de Anatomia Patológica do Hospital Central da Irmandade da Santa Casa de Misericórdia de São Paulo (50 casos), no período de 1985 a 2004; e dos arquivos do Departamento de Histopatologia do Royal National Ortophaedic Hospital, Londres, Grã Bretanha (73 casos). Onze casos que também foram incluídos no estudo foram enviados para diagnóstico de outros hospitais da Grã Bretanha e do Brasil. O material foi composto por biopsias e ressecções. Tecido normal e 194 tumores nos quais o diagnóstico de Sarcoma Sinovial foi excluído, também foram analisados e funcionaram como controle negativos, totalizando 328 casos.

\subsection{Métodos}

Os casos foram obtidos através de levantamento retrospectivo dos Sarcomas diagnosticados no Serviço de Anatomia Patológica da Santa Casa de São Paulo de 1985 a 2004 e no Departamento de Histopatologia do Royal Nacional Ortophaedic Hospital de 2002 a 2006, além de casos enviados para consulta ou complementação do trabalho. Foram revistos e 
relacionados todos os casos com diagnóstico inicial de Sarcoma Sinovial e os casos onde o diagnóstico Sarcoma Sinovial foi aventado como um dos principais diagnósticos diferenciais.

Os laudos anátomo-patológicos, bem como os prontuários dos pacientes, quando disponíveis, foram revistos e dados clínicos foram anotados.

Cento e noventa e quatro outros casos foram incluídos no estudo e utilizados como controle negativo. A escolha destes casos baseou-se na disponibilidade de material para realização de estudo molecular, presença de consentimento informado assinado pelo paciente e em características histopatológicas que apontassem para outro diagnóstico que não Sarcoma Sinovial.

\subsubsection{Caracterização morfológica do Sarcoma Sinovial}

Todos os blocos de parafina disponíveis, em cada caso, foram separados. O material foi processado segundo as normas habituais de fixação e inclusão, empregadas na rotina dos Serviço de Anatomia Patológica da Santa Casa de São Paulo e do Royal National Ortophaedic Hospital. Os blocos foram recortados em secções de três micra $(\mu \mathrm{m})$ de espessura. Seguiu-se a desparafinização em estufa e a coloração pela hematoxilina-eosina (HE). 
O diagnóstico de Sarcoma Sinovial foi baseado em características morfológicas e imuno-histoquímicas descritas previamente, em resumo:

- Subtipo bifásico (BI): incluídos os casos que continham células com características epitelióides, como amplo citoplasma, núcleos grandes e vesiculosos e, ainda, formação de blocos ou arranjos glandulares bem estabelecidos. O outro componente da neoplasia estava representado por células fusiformes com as características descritas no subtipo monofásico fibroso.

- Subtipo monofásico fibroso (MF): incluídos os casos constituídos por células fusiformes curtas, com escasso citoplasma e núcleos ovalados com cromatina regularmente distribuída, células estas dispostas em feixes pequenos.

Todos os casos foram avaliados para a presença de áreas pouco diferenciadas. Os casos foram classificados como contendo áreas pouco diferenciadas, quando cinco ou mais campos de pequeno aumento (lupa) contivessem áreas assim definidas (50):

- arquitetura fascicular hipercelular semelhante a fibrossarcoma de alto grau ou tumor maligno da bainha do nervo periférico com áreas extensas de necrose, preservação de áreas neoplásicas perivasculares e alta atividade mitótica; 
- áreas hipercelulares compostas por células redondas com características intermediárias entre células fusiformes e células epitelióides;

- proliferação de células pequenas e redondas com núcleos hipercromáticos semelhantes a Sarcoma de Ewing / PNET.

Figuras de mitoses foram contadas em dez campos consecutivos de grande aumento (1 CGA= $0.238 \mathrm{~mm}^{2}$ ) em "áreas quentes"; isto é, áreas onde havia aparentemente maior proliferação celular. Para tanto, todos os cortes histológicos obtidos dos blocos de parafina disponíveis em cada caso foram analisados.

\subsubsection{Imuno-histoquímica}

Os casos foram submetidos à reação imuno-histoquímica para os seguintes anticorpos: actina de músculo liso (1A4, diluição 1:25, Dako), desmina (DE-R-11, diluição 1:10, Dako), proteína S-100 (policlonal, diluição 1:1600, Dako), antígeno epitelial de membrana - EMA (E-29, diluição 1:5, Dako), citoqueratinas (através do coquetel de anticorpos monoclonais AE1/AE3, diluição 1:50, Dako) e / ou (MNF116, diluição 1:100, Dako), CD99 (clone 12E7, diluição 1:50, Dako), proteína bcl-2 (clone M0887, diluição 1:10, Dako) e CD34 (diluição 1:25, Dako). Todas as reações foram realizadas no array de tecido utilizando a máquina Ventana NexES Autostainer (Ventana 
Medical Systems, Strasbourg, France) e reveladas através do Diaminobenzidine (DAB).

Foi considerada positiva a reação com evidente marcação de células neoplásicas, independente do número de células imunomarcadas.

\subsubsection{Array de tecido}

Quatro arrays de tecido foram construídos usando o tissue arrayer manual (Beecher Instrumentos Inc., Sun Prarie, WI, EUA). Dos 134 casos iniciais, possuíamos, em 113 casos, material disponível para a realização do array. Duas áreas diferentes de cada caso foram marcadas nos blocos de parafina e um core de $0.6 \mathrm{~mm}$ de cada área foi retirado para a construção de cada array, que foi realizada em duplicata; isto é, procedemos à formação de dois arrays idênticos para 85 casos e dois arrays idênticos para 28 casos. Cento e dezessete cores de tecidos derivados de glândula salivar, rim, placenta e fígado foram usados como controle e marcas de orientação (Figura 2). 
Figura 2. Planejamento esquemático da construção dos arrays de tecido
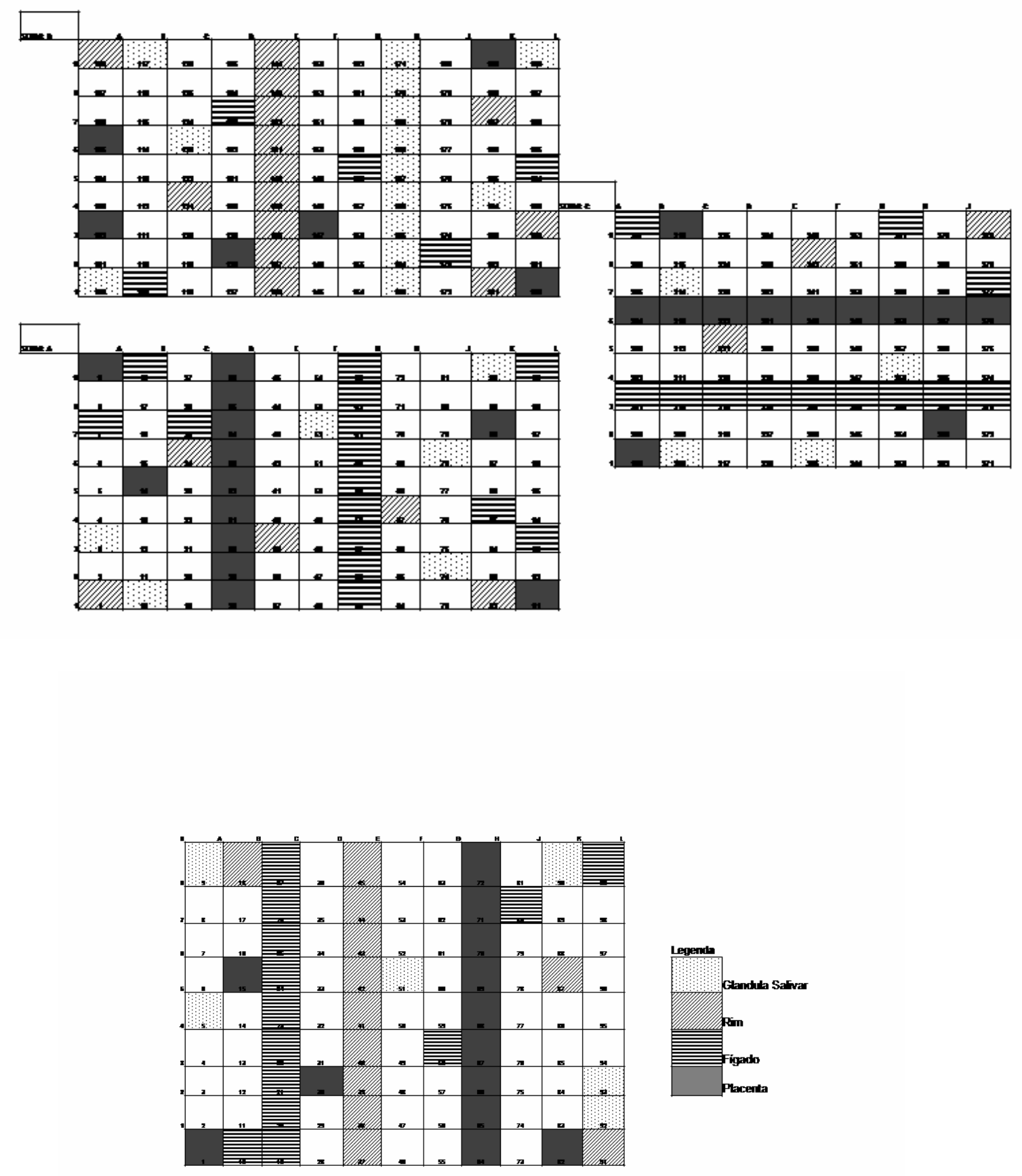


\subsubsection{Extração do RNA}

Um bloco de parafina correspondente a cada caso foi cortado após limpeza com xilol e álcool absoluto do micrótomo e isolamento da área de corte. Uma área virgem da navalha foi utilizada para cada bloco. Duas fatias de $10 \mu \mathrm{m}$ para ressecções ou 5 a 10 fatias de $10 \mu \mathrm{m}$ para biópsias foram colocadas em microtubos de $1.5 \mathrm{ml}$ livres de DNA e RNA. RNA foi extraído usando o kit comercial Optimum ${ }^{\circledR}$ FFPE RNA Isolation (Ambion, UK) com adaptações que consistem em:

1. Centrifugar o microtubo brevemente (10 segundos) para coletar o material no fundo do tubo.

2. Adicionar $1 \mathrm{ml}$ de xilol ao material no tubo, misturar com o vortex por 10 segundos e incubar a temperatura ambiente por 5-10 minutos.

3. Centrifugar a amostra por 5 minutos para formar uma pellet no fundo e cuidadosamente remover o xilol por aspiração.

4. Repetir passos 2 e 3.

5. Adicional $1 \mathrm{ml}$ de álcool etílico a $100 \%$ e misturar vigorosamente no vortex por 10 segundos.

6. Centrifugar a amostra por 5 minutos para formar uma pellet no fundo e cuidadosamente remover o álcool por aspiração.

7. Repetir passos 5 e 6 .

8. Deixar o microtubo aberto aquecido a $37^{\circ} \mathrm{C}$ para secar completamente o material. 
9. Adicionar solução de proteinase $\mathrm{K}$ composta por $10 \mu \mathrm{l}$ de proteinase $\mathrm{K}$ e $100 \mu$ de solução tampão de digestão. Misturar bem a solução ao material para que este fique completamente imerso. Deixar a $37^{\circ} \mathrm{C}$ por 12 horas.

10. Pré-aquecer $30 \mu \mathrm{l}$ de solução de eluição por amostra em microtubo livre de RNA a $75^{\circ} \mathrm{C}$

11. Preparar e rotular os cartuchos com filtro disponíveis no kit.

12. Centrifugar os tubos com o material e adicionar $200 \mu l$ de tampão de extração de RNA, misturar com o vortex por 10 segundos.

13. Centrifugar por 45 segundos e transferir metade da amostra $(235 \mu \mathrm{l})$ para o cartucho com filtro. Centrifugar por 1 minuto à rotação máxima. Adicionar o restante e centrifugar por mais um minuto.

14. Abrir o cartucho e desprezar o filtrado.

15. Adicionar $180 \mu \mathrm{l}$ de Solução para lavagem 1 e centrifugar por 1 minuto. Descartar o filtrado.

16. Adicionar $180 \mu \mathrm{l}$ de Solução para lavagem 2/3 previamente misturada com etanol e centrifugar por 1 minuto. Descartar o filtrado.

17. Repetir passo 16.

18. Centrifugar por 2 minutos para secar o filtro. Transferir o microfiltro para um novo microtubo e adicionar $20 \mu \mathrm{l}$ da solução de eluição previamente aquecida. Centrifugar por 1 minuto.

19. Passar o filtrado novamente pelo filtro e centrifugar por 1 minuto.

20. Separar $1 \mu \mathrm{l}$ de RNA para quantificação e guardar o RNA imediatamente no freezer a $-20^{\circ} \mathrm{C}$ para uso imediato ou a $-80{ }^{\circ} \mathrm{C}$ para armazenamento. 


\subsubsection{Transcrição reversa}

A síntese de cDNA de uma fita a partir do RNA foi realizada utilizando Superscript II First-strand Synthesis kit com modificações segundo protocolo relatado a seguir:

1. Misturar e centrifuguar todos os componentes do kit mantendo-os em gelo.

2. Preparar a combinação do RNA com as seqüências iniciadoras (primers), adicionando a um microtubo de $0.5 \mathrm{ml}$ livre de RNA e DNA

- $\quad$ RNA (idealmente $2 \mu \mathrm{g}$ )

- $\quad$ Primer mix (G6PD AS + SSX1/2B, tabela 1) $1 \mu$ (1pmol)

- 10mM de nucleotídeos $1 \mu \mathrm{l}$

- Água DEPC (dietilpirocarbonato) para completar $10 \mu \mathrm{l}$

3. Incubar por 5 minutos a $65^{\circ} \mathrm{C}$, depois colocar no gelo por 1 minuto e centrifugar brevemente.

4. Adicionar a seguinte mistura por microtubo: $2 \mu \mathrm{l}$ de 10xRT buffer, $4 \mu \mathrm{l}$ de 25mM MgCl $2,2 \mu \mathrm{l}$ de 0.1 M DTT (Dithiothreitol), $1 \mu \mathrm{l}$ de RNaseOUT e 1 $\mu$ de Superscript III.

5. Incubar a $50^{\circ} \mathrm{C}$ por 50 minutos e centrifugar.

6. Inativar a reação a $85{ }^{\circ} \mathrm{C}$ por 15 minutos, esfriar no gelo por 1 minuto, centrifugar.

7. Adicionar $1 \mu$ de $R$ Nase $H$ a cada tubo e incubar por 20 min a $37^{\circ} \mathrm{C}$.

8. Armazenar o cDNA no freezer $\mathrm{a}-20^{\circ} \mathrm{C}$. 


\subsubsection{Reação de cadeia em polimerase quantitativa (qPCR)}

A reação de cadeia em polimerase quantitativa, também chamada Real time PCR, foi realizada no equipamento iCycle iQ detection system (Bio-Rad, UK) programado para leitura do fluorocromo FAM (6-carboxifluoresceína).

As reações foram preparadas usando primers específicos (tabela 1) e sonda marcada com o fluorocromo FAM, ambos desenhados a partir dos locais de fusão entre SS18 e SSX conhecidos (figura 1). As reações foram preparados em um volume total de $25 \mu$ l contendo $12,5 \mu$ le iQ Supermix, água ultrapura, $5 \mathrm{pmol}$ de cada primer e 1 pmol da sonda marcada com FAM. Os parâmetros do termociclador foram os seguintes: 3 minutos a $95{ }^{\circ} \mathrm{C}$, seguido de 55 ciclos de 15 segundos a $94{ }^{\circ} \mathrm{C}$ e 1 minuto a $60{ }^{\circ} \mathrm{C}$. A fluorescência foi constantemente monitorada através do computador no momento de anelamento $\left(60^{\circ} \mathrm{C}\right)$. $\mathrm{O}$ caso foi considerado positivo quando for atingido o limiar do ciclo $\left(C_{T}\right)$ no qual a fluorescência aumenta apreciavelmente além do fundo. $\mathrm{O}$ valor $\mathrm{C}_{\mathrm{T}}$ foi anotado para cada caso.

Digestão por enzimas de restrição para detecção do subtipo SS18SSX gerado por qPRC.

Três microlitros de produto da reação de $\mathrm{qPCR}$ foram misturados a $0.5 \mu l$ da enzima de restrição, $1 \mu \mathrm{l}$ de solução tampão e $5.5 \mu \mathrm{l}$ água. A enzima utilizada foi a Xmnl (New England Biolabs) derivado do Xanthomonas axonopodis. A solução foi incubada a $37{ }^{\circ} \mathrm{C}$ por duas horas. 
Os produtos foram separados através de eletroforese em gel de poliacrilamida a 10\%. Produtos não digeridos, mantendo 95 pares de bases foram interpretados como SS18-SSX1 e produtos digeridos em 56 e 39 pares de base interpretados como SS18-SSX2.

Tabela 1. Primers, sonda e tamanho de produto esperado para for SS18, SSX and G6PD

\begin{tabular}{|c|c|c|}
\hline & Sequência dos Primers 5' - 3' & $\begin{array}{l}\text { Tamanho do } \\
\text { produto (pb) }\end{array}$ \\
\hline $\begin{array}{l}\text { Primers de } \\
\text { Transcrição } \\
\text { reversa }\end{array}$ & $\begin{array}{l}\text { SSX-1/2-B Anti-sense CRTTTTGTGGGCCAGATGC } \\
\text { G6PD Anti-sense CGAAGTGCATCTGGCTCC }\end{array}$ & \\
\hline $\begin{array}{l}\text { Primers } \\
\text { qRT-PCR }\end{array}$ & $\begin{array}{l}\text { SYT-B-RT Sense AGAGGCCTTATGGATATGACCA } \\
\text { SSX1-2-B Anti-sense CRTTTTGTGGGCCAGATGC } \\
\text { Sonda: FAM-ATCATGCCCAAGAAGCCAGCAGAGG-TAMRA }\end{array}$ & 95 \\
\hline $\begin{array}{l}\text { Primers } \\
\text { RT-PCR } \\
\text { Convencional }\end{array}$ & $\begin{array}{l}\text { SSA Sense AGACCAACACAGCCTGGACCAC } \\
\text { SSX1 Anti-sense ACACTCCCTTCGAATCATTTTCG } \\
\text { SSX2 Anti-sense GCACTTCCTCCGAATCATTTC } \\
\text { SSX4 Anti-sense GCACTTCCTTCAAACCATTTTCT }\end{array}$ & 108 \\
\hline $\begin{array}{l}\text { Primers } \\
\text { RT-PCR } \\
\text { Convencional } \\
\text { G6PD }\end{array}$ & $\begin{array}{l}\text { G6PD } 86 \text { Sense ACGGCAACAGATACAAGAAC } \\
\text { G6PD } 141 \text { Sense CCAAGAAGCCGGGCATGT } \\
\text { G6PD } 200 \text { Sense GCGCAACGAGCTGGTGAT } \\
\text { G6PD Anti-sense CGAAGTGCATCTGGCTCC }\end{array}$ & $\begin{array}{r}86 \\
141 \\
200\end{array}$ \\
\hline $\begin{array}{l}\text { Primers } \\
\text { RT-PCR } \\
\text { Convencional } \\
\text { variantes raras }\end{array}$ & $\begin{array}{l}\text { SYTexon9 Sense AAGATGCATACCAGGGACCA } \\
\text { SYTexon10 Sense CTACCCACAGGGACAAGGTC } \\
\text { SSX1exon4 Anti-sense CTGGAAGTCTGTGGCCTGTT } \\
\text { SSX2exon4 Anti-sense AAGTCTTCGGCCCGTTTATT } \\
\text { SSX4exon3 Anti-sense GACGATTTTCTCCGAGGATTT } \\
\text { SSX4exon7 Anti-sense ACCACCAGCTGCTTTCTCTC }\end{array}$ & $\begin{array}{l}134 \\
155 \\
130 \\
150 \\
170\end{array}$ \\
\hline
\end{tabular}

pb pares de base 


\subsubsection{Reação de Cadeia em Polimerase Convencional}

A amplificação foi realizada em duplicata para cada caso, utilizando alíquotas de $1 \mu \mathrm{l}$ de cDNA e primers específicos (tabela 1 ) gerados com base nos locais de fusão comumente observados para os genes SS18 e SSX no SS (figura 1).

As reações foram preparados em um volume total de $25 \mu \mathrm{l}$ contendo 1x tampão II (Applied Biosystems, UK), água ultrapura, $200 \mu \mathrm{M}$ de cada dNTP, 5 pmol de cada primer, $1.5 \mathrm{mM}$ de $\mathrm{MgCl}_{2}$ e 1 unidade da enzima Amplitaq Gold (Applied Biosystems, UK). Os parâmetros do termociclador seguiram o protocolo touchdown detalhado a seguir: 7 minutos a $95{ }^{\circ} \mathrm{C}$, seguido por 45 segundos a $94{ }^{\circ} \mathrm{C}, 45$ segundos a $66{ }^{\circ} \mathrm{C}, 1$ minuto e trinta segundos a $72{ }^{\circ} \mathrm{C}$. Esta seqüência foi seguida por redução de $1{ }^{\circ} \mathrm{C}$ da temperatura de anelamento em cada ciclo até atingir $57{ }^{\circ} \mathrm{C}$ (10 ciclos); seguido por 30 ciclos com temperatura de anelamento a $56{ }^{\circ} \mathrm{C}$ e finalizando com 5 minutos a $72{ }^{\circ} \mathrm{C}$.

As fusões SS18-SSX1 e SS18-SSX2 foram separadas usando os pares de primers SSA-SSX1 e SSA-SSX2 respectivamente. Os produtos foram separados através de eletroforese em gel de poliacrilamida a $8 \%$, revelados com brometo de etídio e visualizados por iluminação ultravioleta usando o sistema BioRad Gel Doc $2000^{\mathrm{TM}}$. As amostras que geraram o produto esperado de 108 pb em ambas as reações (duplicadas) foram consideradas positivas. 


\subsubsection{Controles para RT-PCR}

Um controle negativo (sem DNA) e um controle positivo (gene de fusão SS18-SSX previamente sequenciado) foram utilizados em cada experimento. O gene housekeeping G6PD (Glicose-6-fosfato desidrogenase) foi amplificado através dos mesmos parâmetros e condições descritos para o RT-PCR convencional. Os primers foram estruturados para gerarem produtos de 86 pb, 141 pb e 200 pb para controle da qualidade do RNA.

\subsubsection{Hibridização in situ por fluorescência (FISH)}

A técnica de FISH foi utilizada nos arrays de tecido após otimização do protocolo para utilização da sonda comercial de rearranjo gênico SYT de duas cores (LSI SYT Dual Colour Break-Apart Rearrangment Probe - Vysis, Abbott Laboratories, UK) . Os testes e a otimização do protocolo foram realizados em lâminas de metáfase e, posteriormente, em 10 casos de SS utilizando cortes completos de blocos de parafina oriundos de ressecção.

LSI SYT é composta de duas sondas de DNA desenhadas para serem posicionadas em ambos os lados do gene SS18. Uma sonda é marcada com fluorescência laranja (spectrum orange ${ }^{\mathrm{TM}}$ ) e posicionada na região telomérica 5' ao SS18 e contém 650 Kb. A outra sonda é marcada com fluorescência verde (spectrum green ${ }^{\mathrm{TM}}$ ) e posicionada na região centromérica 3' ao SS18 e contém 1040 Kb. 
Os blocos do array foram seccionados com 1 a $2 \mu \mathrm{m}$ de espessura e os cortes foram posicionados em lâminas de vidro carregadas eletricamente para melhor fixação dos cortes. As lâminas foram aquecidas a $60^{\circ} \mathrm{C}$ por 12 horas e desparafinadas através da imersão solução de xilol por 5 minutos (repetida por 3 vezes) e desidratadas em álcool etílico $3 \times 3$ minutos. Posteriormente, as lâminas foram imersas em solução de pré-tratamento (Paraffin Pretreatment reagent kit, Vysis) aquecida a $80^{\circ} \mathrm{C}$ por 50 minutos. Seguiu-se a imersão das lâminas em água destilada por 3 minutos e solução de proteinase (Paraffin Pretreatment reagent kit, Vysis) a $37^{\circ} \mathrm{C}$ por 20 minutos, após a qual as lâminas foram lavadas com água destilada e desidratadas durante um minuto em solução de álcool etílico com concentrações crescentes (70\%, 80\% e 100\%).

Após secagem a temperatura ambiente seguiu-se a aplicação de 10 $\mu \mathrm{l}$ da mistura das sondas $(1 \mu \mathrm{l}$ das sondas marcadas, $2 \mu \mathrm{l}$ de água destilada e $7 \mu$ de tampão para hibridização) sobre cada lâmina. A lamínula foi posicionada e selada com cimento de borracha.

As lâminas foram desnaturadas por 5 minutos a $73^{\circ} \mathrm{C}$ e seguiu-se a hibridização por no mínimo 16 horas a $37^{\circ} \mathrm{C}$. Os dois últimos passos foram realizados em câmera úmida (ThermoBrite hybridizer).

No dia seguinte, as lâminas foram lavadas em 2x solução de citrato de sódio salino (SSC) com 0,3\%NP40 a temperatura ambiente por 5 minutos e a $73{ }^{\circ} \mathrm{C}$ por 2 minutos, repetindo, então, a lavagem a temperatura ambiente por 1 minuto. Após secagem no escuro, as lâminas foram montadas com Vectashield com e sem 4'6' Diamino-2- fenilindoli (DAPI) em iguais proporções. As lamínulas foram seladas com esmalte de unha incolor. 
As lâminas foram analisadas sob fluorescência utilizando microscópio equipado com filtro triplo para DAPI/ FITC/ Rodamine e ligado a um microcomputador contendo o programa de registro AnalySIS (Olympus).

Cinqüenta núcleos claramente individualizados e contendo sinais inequívocos foram contados para cada caso. As sondas foram consideradas como separadas se tivessem mais do que o tamanho de um sinal de hibridização entre elas. Este valor foi escolhido porque a distância entre as sondas no cromossomo 18 íntegro é de $56 \mathrm{~Kb}$ e a sonda menor tem o tamanho de 650Kb. Quando 20\% ou mais núcleos apresentassem um sinal fusionado e dois sinais separados (laranja e verde), o caso foi considerado positivo para o rearranjo do gene SS18. A análise do FISH foi realizada sem conhecimento do resultado de RT-PCR.

\subsubsection{Análise estatística}

A análise dos dados foi desenvolvida através de tabelas e testes produzidos no SPSS 10.0 for Windows. Para análise comparativa dos dados foi aplicado o Teste de Qui-quadrado ou o Teste Exato de Fisher, a fim de verificar se existe associação entre as variáveis de interesse. Diferenças foram consideradas estatisticamente significantes se $p<0.05$. 


\section{Resultados}

\subsection{Características clínicas e histológicas}

Sarcoma Sinovial foi o principal diagnóstico ou esteve entre os principais diferenciais em 134 casos com base em características clínicas, histológicas e imuno-histoquímicas. A idade dos pacientes variou de 5 a 81 anos, média de 35 anos. Quanto ao gênero, 65 pacientes do sexo feminino e 69 pacientes do sexo masculino (razão feminino:masculino de 1:1.06).

Em 97 casos (72\%), Sarcoma Sinovial foi concluído como o principal diagnóstico e em 37 casos (28\%) Sarcoma Sinovial estava entre os principais diagnósticos diferenciais.

Dos 134 casos estudados, 76 eram peças cirúrgicas e 58 eram biopsias. Necrose foi observada em 60 casos (45\%). Em 9 casos (6\%) a necrose foi focal (0-25\%) da área tumoral, em 42 (31\%) casos a necrose ocupava de 26 a 50\% da área tumoral e em 9 casos (8\%) a necrose ocupava mais de $50 \%$ da área tumoral. Necrose não foi observada em 74 $\operatorname{casos}(55 \%)$.

Quanto à topografia, a maioria dos pacientes apresentava a neoplasia localizada nas nos membros (80\%) O Sarcoma Sinovial incidiu preferencialmente nod membros inferiores (61\%), quanto aos membros superiores, a freqüência foi de 19\%. Já o tórax ocupou a terceira localização em termos de freqüência (Tabela 2). 
Tabela 2. Localização anatômica de 134 neoplasias consideradas como Sarcoma Sinovial.

\begin{tabular}{|c|c|c|c|c|c|}
\hline \multirow[t]{2}{*}{ Localização geral } & \multicolumn{2}{|c|}{ Casos } & \multirow[t]{2}{*}{ Localização específica } & \multicolumn{2}{|c|}{ Casos } \\
\hline & $\mathrm{n}$ & $\%$ & & $\mathrm{n}$ & $\%$ \\
\hline \multirow[t]{8}{*}{ Membro inferior } & 80 & $61 \%$ & & & \\
\hline & & & Coxa & 28 & $21 \%$ \\
\hline & & & Joelho & 18 & $14 \%$ \\
\hline & & & Pé & 12 & $9 \%$ \\
\hline & & & Perna & 9 & $7 \%$ \\
\hline & & & Tornozelo & 8 & $6 \%$ \\
\hline & & & Inguinal & 3 & $2 \%$ \\
\hline & & & Nádega & 2 & $2 \%$ \\
\hline \multirow[t]{8}{*}{ Membro Superior } & 25 & $19 \%$ & & & \\
\hline & & & Antebraço & 7 & $5 \%$ \\
\hline & & & Braço & 6 & $5 \%$ \\
\hline & & & Mão & 5 & $4 \%$ \\
\hline & & & Ombro & 4 & $3 \%$ \\
\hline & & & Cotovelo & 1 & $1 \%$ \\
\hline & & & Ulna* & 1 & $1 \%$ \\
\hline & & & Pulso & 1 & $1 \%$ \\
\hline \multirow[t]{8}{*}{ Tórax } & 17 & $13 \%$ & & & \\
\hline & & & Pleura & 6 & $5 \%$ \\
\hline & & & Pulmão & 5 & $4 \%$ \\
\hline & & & Parede torácica & 2 & $2 \%$ \\
\hline & & & Mediastinal & 1 & $1 \%$ \\
\hline & & & Cardíaco & 1 & $1 \%$ \\
\hline & & & Escapular & 1 & $1 \%$ \\
\hline & & & Supraclavicular & 1 & $1 \%$ \\
\hline \multirow[t]{5}{*}{ Cabeça e pescoço } & 4 & $3 \%$ & & & \\
\hline & & & Infratemporal & 1 & $1 \%$ \\
\hline & & & Maxila & 1 & $1 \%$ \\
\hline & & & Submental & 1 & $1 \%$ \\
\hline & & & Supraglótico & 1 & $1 \%$ \\
\hline \multirow[t]{3}{*}{ Retroperitônio } & 2 & $2 \%$ & & & \\
\hline & & & Rim & 1 & $1 \%$ \\
\hline & & & Pararrenal & 1 & $1 \%$ \\
\hline Indefinido & 4 & $3 \%$ & & & \\
\hline
\end{tabular}




\subsubsection{Subtipo histológico}

Cento e três casos (77\%) foram classificados como Sarcoma Sinovial monofásico fibroso e 31 casos (23\%) como Sarcoma Sinovial bifásico.

Áreas pouco diferenciadas foram identificadas em 44 casos (33\%).

Tabela 3. Presença de áreas pouco diferenciadas por subtipo histológico

\begin{tabular}{|c|c|c|}
\hline $\begin{array}{l}\text { Subtipo } \\
\text { histológico }\end{array}$ & n (\%) & $\begin{array}{c}\text { Presença de áreas } \\
\text { pouco diferenciadas } \\
\text { n (\%) }\end{array}$ \\
\hline Bifásico & $31 \quad(23 \%)$ & $5 \quad(4 \%)$ \\
\hline Monofásico & $103(77 \%)$ & 39 (29\%) \\
\hline
\end{tabular}

Dos 44 casos contendo áreas pouco diferenciadas, 26 (62\%) apresentavam áreas hipercelulares compostas por células redondas com características intermediárias entre células fusiformes e células epitelióides. Em 12 casos (28.5\%) havia densa proliferação de células pequenas e redondas. Em quatro casos (9.5\%) as áreas pouco diferenciadas eram caracterizadas por hipercelularidade com núcleos hipercromáticos, arquitetura fascicular, com áreas extensas de necrose, preservação de áreas neoplásicas perivasculares e alta atividade mitótica. 


\subsection{2. Índice mitótico}

O índice mitótico, obtido através da contagem de figuras de mitose em dez CGA, variou de 1 a 54 figuras de mitose (média=13,5). Quando a análise foi restrita aos casos contendo áreas pouco diferenciadas, a contagem de figuras de mitose variou de 2 a 54 figuras de mitose (média=25,4).

Quando o índice mitótico foi separado em três categorias, obtivemos os seguintes resultados:

1 a 9 figuras de mitoses $/$ 10CGA = 66 casos $(50 \%)$

10 a 19 figuras de mitoses $/ 10 C G A=29$ casos $(22 \%)$

$>20$ figuras de mitoses $/$ 10CGA $=37$ casos $(28 \%)$

Observamos correlação estatística entre a presença de mais de 20 figuras de mitoses/dez CGA e presença de áreas pouco diferenciadas $(p<0.001)$. 
4.1.3. Resultados imuno-histoquímicos

Encontramos positividade para anticorpo anti-citoqueratina em 80\% dos casos. Dentre marcadores epiteliais, o EMA foi positivo em 98\% dos casos.

A presença do antígeno da proteína S-100 foi detectada em 22\% dos casos. Nestes, a imuno-expressão foi focal.

A imuno-expressão da proteína bcl-2 ocorreu em $97.5 \%$ dos casos e de CD99 em 70\% dos casos.

As células neoplásicas foram positivas para CD34 em apenas um caso. Todos os casos testados foram negativos para desmina e actina de músculo liso. 

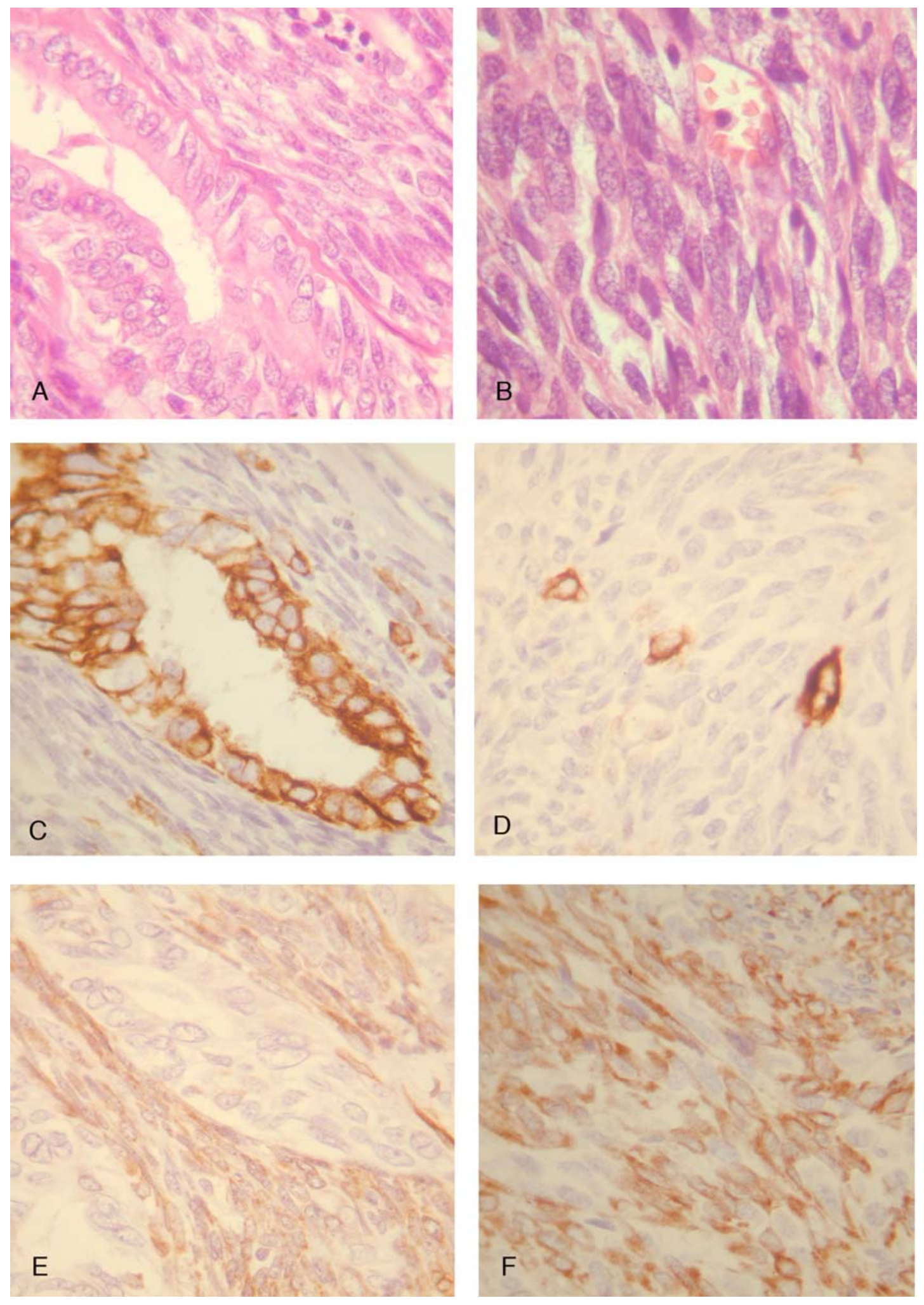

Figura 3. Microfotografia dos subtipos bifásico - HE (A); AE1/AE3 (C); bcl-2 (E) -Imuno-histoquímica 400X e monofásico fibroso - HE (B); AE1/AE3 (D); bcl-2 (F) -Imuno-histoquímica 400X 


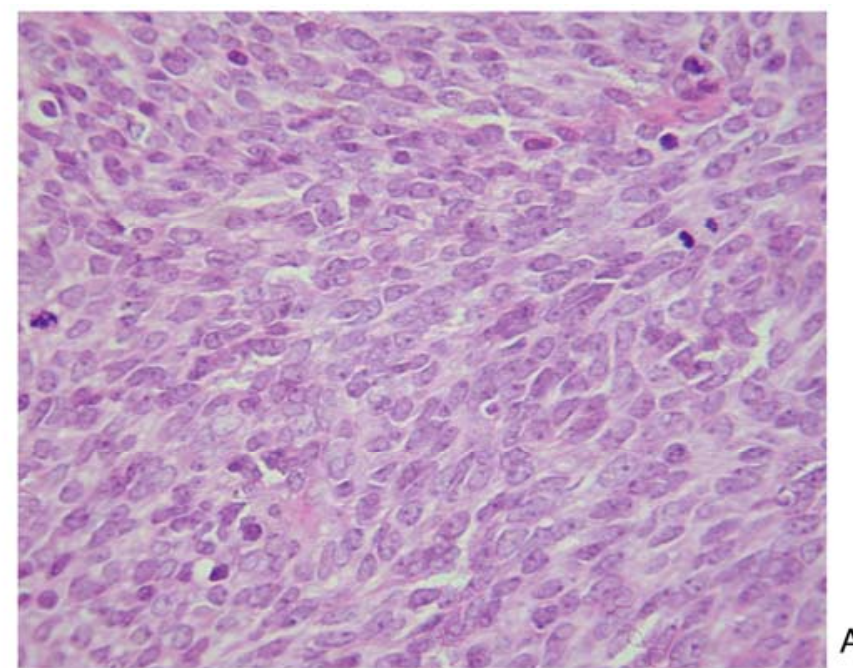

A
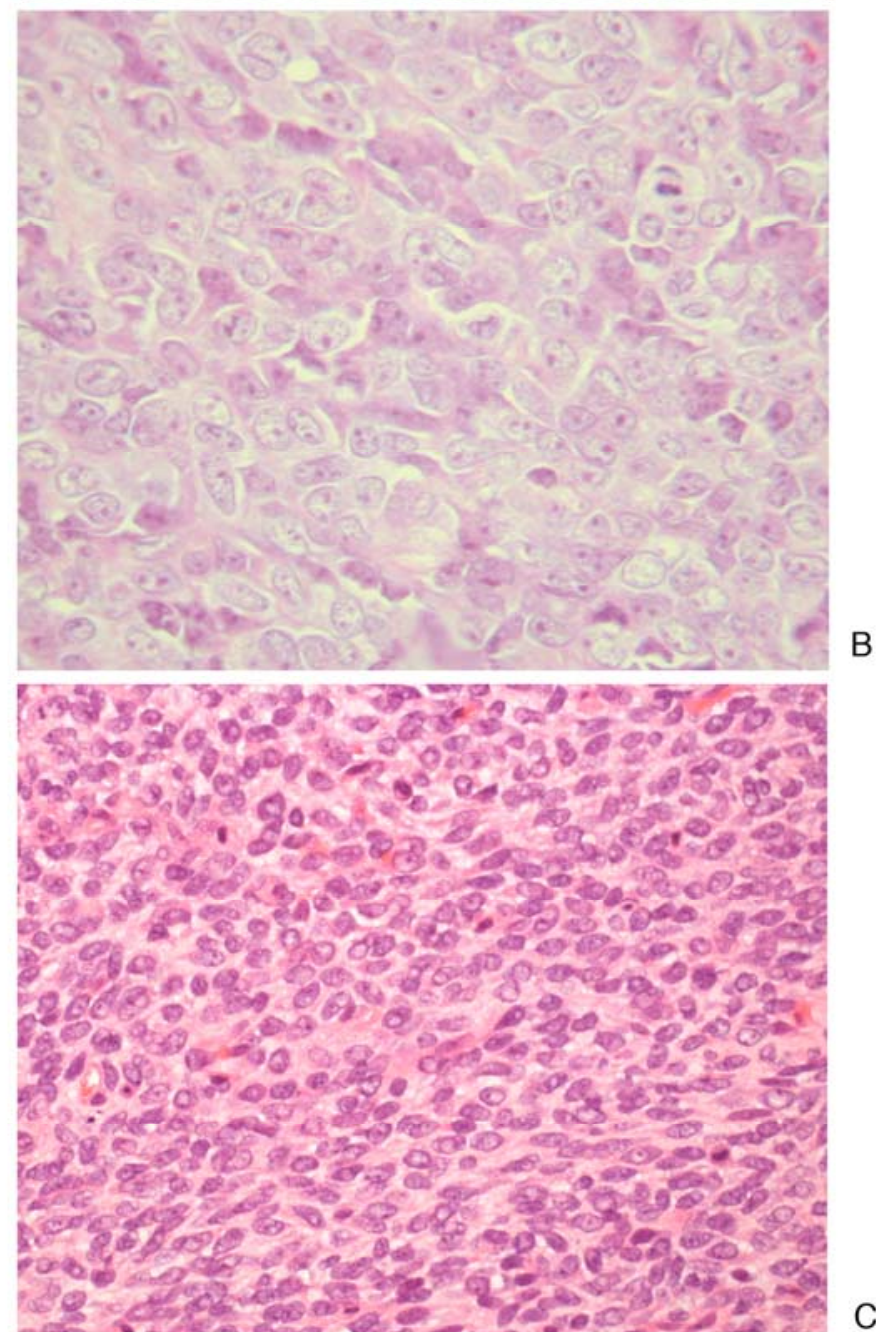

C

Figura 4.

Microfotografia de áreas pouco diferenciadas HE - 400X 
4.2. Resultados quanto à detecção da fusão SS18-SSX

Dos 134 analisados, três não geraram produtos usando os primers para a fusão SS18-SSX ou para o gene "housekeeping" G6PD (Glicose-6fosfato desidrogenase). Estes casos foram considerados como contendo RNA de qualidade insuficiente para a avaliação.

Cento e trinta e um casos foram considerados como contendo RNA de qualidade suficiente para a análise, por gerarem produtos de 95 ou 108 pb através dos primers para a fusão SS18-SSX e/ou produtos de 89 e 141 pb através dos primers para G6PD.

Dos 131 casos acima, 126 (96\%) foram positivos por qRT-PCR; isto é, foram positivos para a fusão SS18-SSX. Os cinco casos negativos geraram produtos de 89, 141 e 200 pb para G6PD, indicando RNA de qualidade adequada na amostra.

Dos mesmos 131 casos, 120 (92\%) foram positivos por RT-PCR convencional, 119 amplificando produtos de 108 pb para SS18-SSX1 ou SSX18-SSX2 e um caso gerando um produto cerca de 50 pb maior que o esperado. Caso este que foi seqüenciado e descrito como uma variante da fusão SS18-SSX1. 
A técnica de RT-PCR convencional não detectou a fusão SS18-SSX em 11 casos utilizando-se os primers desenhados para as fusões SS18SSX1, SS18-SSX2 e SS18-SSX4 na geração de produtos de 108 pb. Os mesmos 11 casos foram negativos para os primers desenhados para as variantes raras descritas (tabela 1), incluindo a variante SS18LI-SSX1. Cinco destes casos também foram negativos pela técnica de qRT-PCR. Dos seis casos restantes, a fusão SS18-SSX foi detectada em três casos utilizando os primers empregados nos experimentos de qRT-PCR (produtos de $95 \mathrm{pb}$ ) com os parâmetros e a metodologia do RT-PCR convencional.

\subsection{Resultados quanto ao tipo de fusão SS18-SSX}

Quanto ao tipo de fusão, 74 casos (59\%) mostraram a fusão SS18SSX1 e 52 casos (41\%) a fusão SS18-SSX2.

Em 120 casos, o tipo de fusão foi determinado diretamente através dos primers específicos utilizados em RT-PCR convencional (tabela 1). Nos seis casos positivos por qRT-PCR mas negativos por RT-PCR convencional, o tipo de fusão foi determinado através da técnica de enzimas de restrição (SS18-SSX1 em quatro casos e SS18-SSX2 em dois casos). 
Tabela 4. Relação entre tipo de fusão SS18-SSX e subtipo histológico

\begin{tabular}{|c|c|c|c|c|}
\hline $\begin{array}{l}\text { Subtipo } \\
\text { Histológico } \\
\text { n (\%) }\end{array}$ & $\begin{array}{c}\text { Tipo de fusão } \\
\text { SS18-SSX }\end{array}$ & $\mathbf{n}$ & $\begin{array}{c}\text { Areas PD } \\
\text { n (\%) }\end{array}$ & $\begin{array}{l}\text { Tipo de fusão e } \\
\text { áreas PD (n) }\end{array}$ \\
\hline Bifásico & SS18-SSX1 & 18 & 5 & SS18-SSX1 (3) \\
\hline \multirow[t]{3}{*}{$31 \quad(23 \%)$} & SS18-SSX2 & 11 & & SS18-SSX2 (2) \\
\hline & Negativos & 1 & & \\
\hline & N/A & 1 & & \\
\hline Monofásico & SS18-SSX1 & 56 & 39 & SS18-SSX1 (18) \\
\hline \multirow[t]{3}{*}{$103(77 \%)$} & SS18-SSX2 & 41 & & SS18-SSX2 (18) \\
\hline & Negativos & 4 & & Negativos (3) \\
\hline & $\mathrm{N} / \mathrm{A}$ & 2 & & \\
\hline Total & SS18-SSX1 & 74 & 44 & SS18-SSX1 (21) \\
\hline \multirow[t]{3}{*}{$134(100 \%)$} & SS18-SSX2 & 52 & & SS18-SSX2 (20) \\
\hline & Negativos & 5 & & Negativos 3 \\
\hline & RNA insuficiente & 3 & & \\
\hline
\end{tabular}

N/A = Não amplificado, $\mathrm{PD}=$ pouco diferenciado, $\mathrm{n}$ = número

4.4. Análise estatística quanto ao tipo de fusão SS18-SSX

O tipo de fusão foi confrontado com os seguintes parâmetros analisados: sexo, localização, presença de necrose, subtipo histológico, presença de áreas pouco diferenciadas, tipo de área pouco diferenciada, contagem de mitoses e marcadores imuno-histoquímicos. Os valores de $p$ estão reportados na tabela 5. 
Tabela 5. Relação entre tipo de fusão SS18-SSX e demais variáveis.

\begin{tabular}{|c|c|c|c|c|}
\hline & & SS18-SSX1 & SS18-SSX2 & $\mathrm{p}$ \\
\hline \multirow[t]{2}{*}{ Sexo } & feminino & 39 & 24 & \multirow{2}{*}{0.294} \\
\hline & masculino & 35 & 28 & \\
\hline \multirow[t]{4}{*}{ Local } & membro inferior & 50 & 26 & \multirow{4}{*}{0.216} \\
\hline & membro superior & 15 & 10 & \\
\hline & cabeça e pescoço / tórax & 7 & 11 & \\
\hline & pélvis / retroperitônio & 2 & 1 & \\
\hline \multirow[t]{2}{*}{ Subtipo } & $\mathrm{BP}$ & 18 & 11 & \multirow{2}{*}{0.423} \\
\hline & MP & 56 & 41 & \\
\hline \multirow[t]{2}{*}{ PD } & ausente & 53 & 32 & \multirow{2}{*}{0.160} \\
\hline & presente & 21 & 20 & \\
\hline \multirow{4}{*}{$\begin{array}{c}\text { Tipo de } \\
\text { PD }\end{array}$} & grandes células & 13 & 13 & \multirow{4}{*}{0.075} \\
\hline & pequenas células & 8 & 3 & \\
\hline & hipercelular / células & 0 & 3 & \\
\hline & fusiformes & & & \\
\hline \multirow{3}{*}{ Mitoses } & 0-9/10CGA & 36 & 26 & \multirow{3}{*}{0.535} \\
\hline & 10-19/10CGA & 19 & 9 & \\
\hline & $>20 / 10 C G A$ & 19 & 16 & \\
\hline $\mathrm{CK}$ & negativo & 8 & 16 & 0000 \\
\hline $\mathrm{IH}$ & positivo & 64 & 32 & \\
\hline \multirow{2}{*}{ EMA } & negativo & 1 & 1 & \multirow{2}{*}{0.646} \\
\hline & positivo & 70 & 47 & \\
\hline \multirow{2}{*}{$b c l-2$} & negativo & 2 & 0 & \multirow{2}{*}{0.358} \\
\hline & positivo & 70 & 48 & \\
\hline \multirow{2}{*}{ S100 } & negativo & 56 & 37 & \multirow{2}{*}{0.405} \\
\hline & positivo & 17 & 9 & \\
\hline
\end{tabular}


Observou-se diferença estatisticamente significante entre a associação da variável citoqueratina e do tipo de fusão $(p=0.003)$. Os casos negativos para citoqueratina estão associados à fusão SS18-SSX2, enquanto os casos positivos estão associados à fusão SS18-SSX1.

Ao confrontar a presença de áreas pouco diferenciadas com as demais variáveis, nota-se associação estatisticamente significante com índice mitótico $(p<0.000)$.

Por sua vez, ao confrontar a presença de áreas pouco diferenciadas com o subtipo histológico, a associação não é tão clara quando analisada face às porcentagens; porém o subtipo bifásico não se mostra tão associado à presença de áreas pouco diferenciadas (tabela 6).

Tabela 6. Relação entre subtipo histológico e presença de áreas pouco diferenciadas

Subtipo

Total

\section{Ausência de Presença de} áreas PD

BP MP

$$
26 \text { (83.9\%) }
$$

64 (62.1\%)

90 áreas PD

$5(16.1 \%)$

p

(t. de Fisher)

39 (37.9\%)

44 
4.5. Resultados dos casos utilizados como controle negativo

Dos 194 casos representados por lesões que não foram consideradas compatíveis com SS, nenhum apresentou amplificação da fusão SS18-SSX. A maioria dos casos utilizados foi diagnosticada com outro tipo alteração molecular (Tabela 7).

Tabela 7. Casos cujo diagnóstico de SS foi considerado improvável, analisados por RT-PCR para a fusão SS18-SSX e outras alterações.

$\mathrm{n}$

PNET/ Sarcoma de Ewing

Lipossarcoma Mixóide

Sarcoma de células claras

Condrossarcoma mixóide extra-esquelético

Rabdomiossarcoma alveolar

Tumor desmoplásico de pequenas células

Sarcoma fibromixóide de baixo grau

Outros tumores de osso e tecidos moles

Total
68

7

12

8

4

4

2

4

85

194

Resultado molecular

EWS-FLII

EWS-ERG

FUS-CHOP

EWS-ATF1

EWS12-CHN3

PAX -FKHR

EWS/WT1

FUS-CREB 


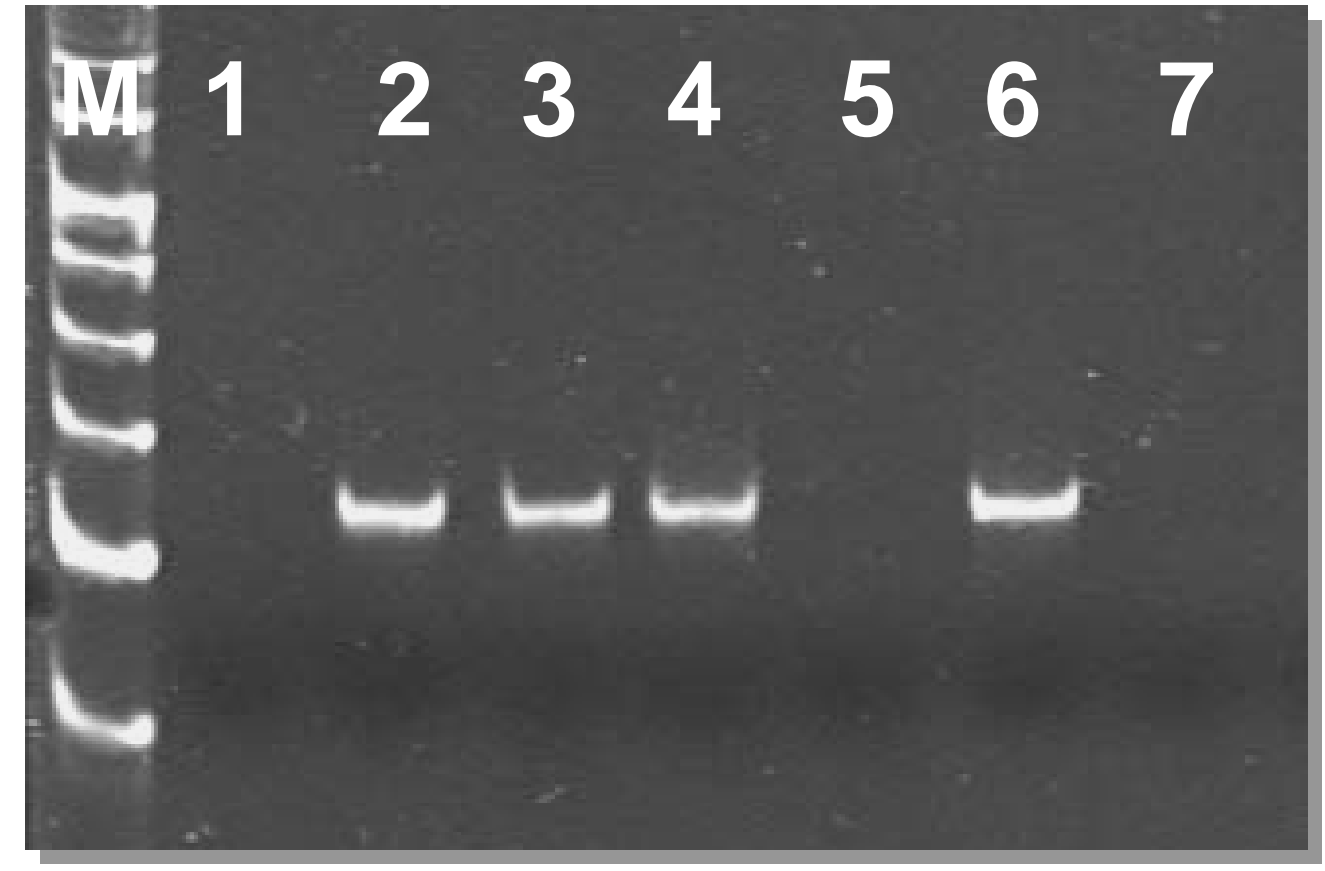

Figura 5. Análise de um caso de SS positivo, em duplicata para a fusão SS18SSX1 por RT-PCR. Gel de poliacrilamida a 8\%: Coluna $M$ - marcador de peso molecular (50pb); 1 e 5 - controles negativos; colunas 2 e 6 - controles positivo para SS18-SSX1 e SS18-SSX2 respectivamente; colunas 3 e 4 caso positivo em duplicata para SS18-SSX1; coluna 7 - negativo para SS18-SSX2.

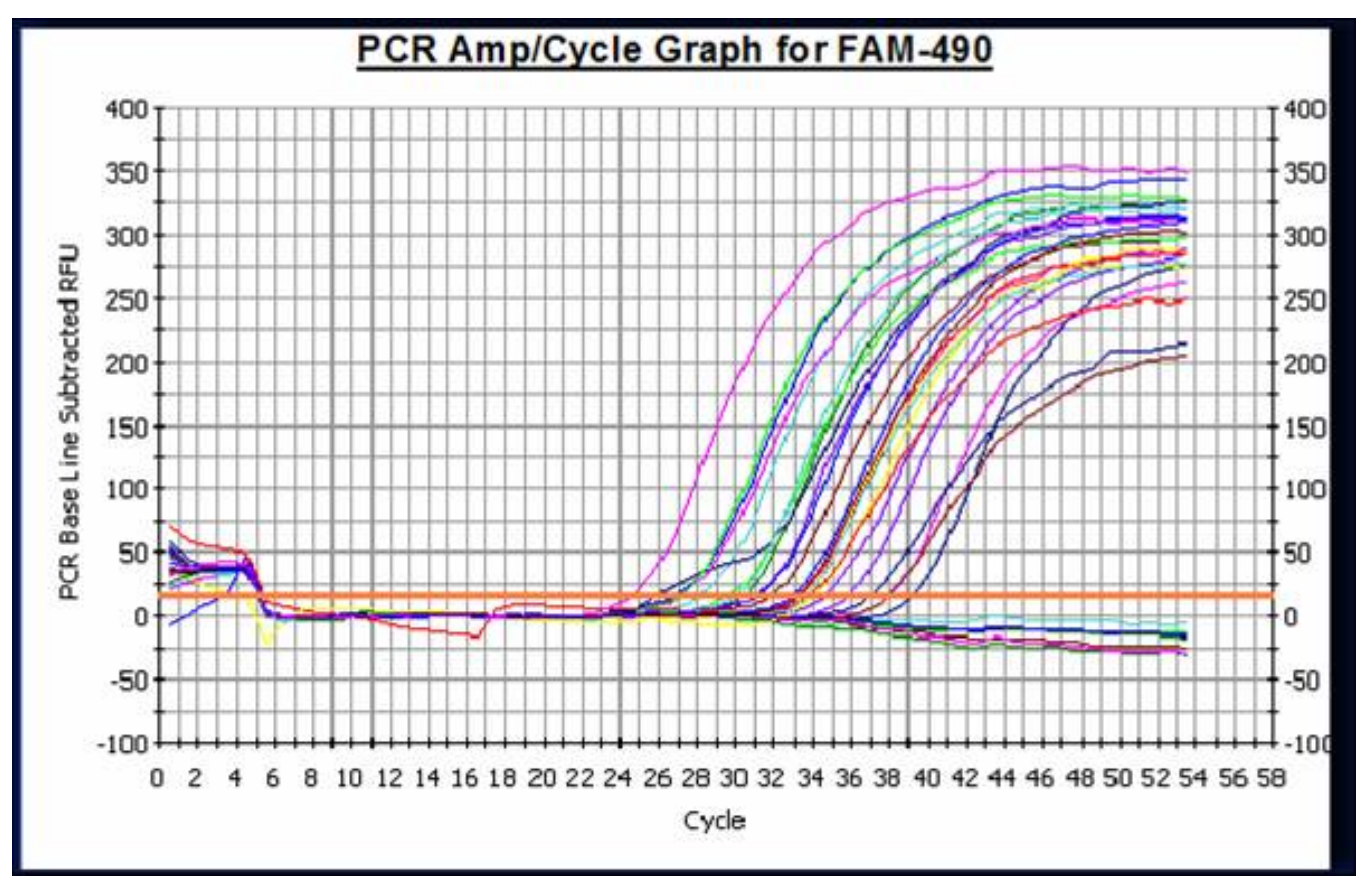

Figura 6. Resultado de qRT-PCR em 25 casos demonstrando diversos valores do limiar do ciclo (cT) . 
4.6. Resultados quanto à detecção de rearranjo de SS18 por FISH

Dos 113 casos incluídos no array de tecido e submetidos à reação de FISH, 12 (11\%) não puderam ser avaliados devido à perda do material durante o processamento da reação $(n=4)$ ou sinal de fluorescência ausente ou muito fraco $(n=8)$. Dos 101 casos remanescentes, 87 (86\%) demonstraram rearranjo do gene SS18 através da separação das duas sondas, verde e laranja, de DNA em 21\% a 74\% das células (média 50\%).

Quatorze casos não mostraram rearranjo de SS18. Cinco destes foram negativos por RT-PCR e nove mostraram a fusão SS18-SSX por RTPCR quantitativo e convencional $(n=8)$ e um caso somente por qRT-PCR.

A análise detalhada destes nove casos classificados como negativos por FISH mostrou em quatro deles um sinal fusionado (verde e laranja) e um sinal laranja isolado em mais de $70 \%$ das células; isto é, houve perda do sinal da sonda marcada em verde nestes casos. Um sinal fusionado e a separação das sondas verde e laranja foi, entretando, detectado células ocasionais nestes quatro casos $(2 \%, 4 \%, 6 \%$ e $8 \%)$.

Nos outros cinco casos dentre os nove classificados como negativos, um sinal fusionado e a separação das sondas verde e laranja foi detectada em $2 \%$ a $4 \%$ das células em três casos e dois casos foram completamente negativos.

Quinze casos mostraram mais de duas cópias por célula da região do gene SS18, 14 destes foram caracterizados como positivos em mais de $20 \%$ 
das células e um foi negativo, com somente $2 \%$ das células mostrando um sinal fusionado e a separação das sondas verde e laranja.

Dos três casos considerados como contendo RNA de qualidade insuficiente para a avaliação por RT-PCR, um foi positivo através da análise pelo FISH. Um segundo foi testado, mas não revelou sinais para serem avaliados e o último não possuía material disponível para avaliação.

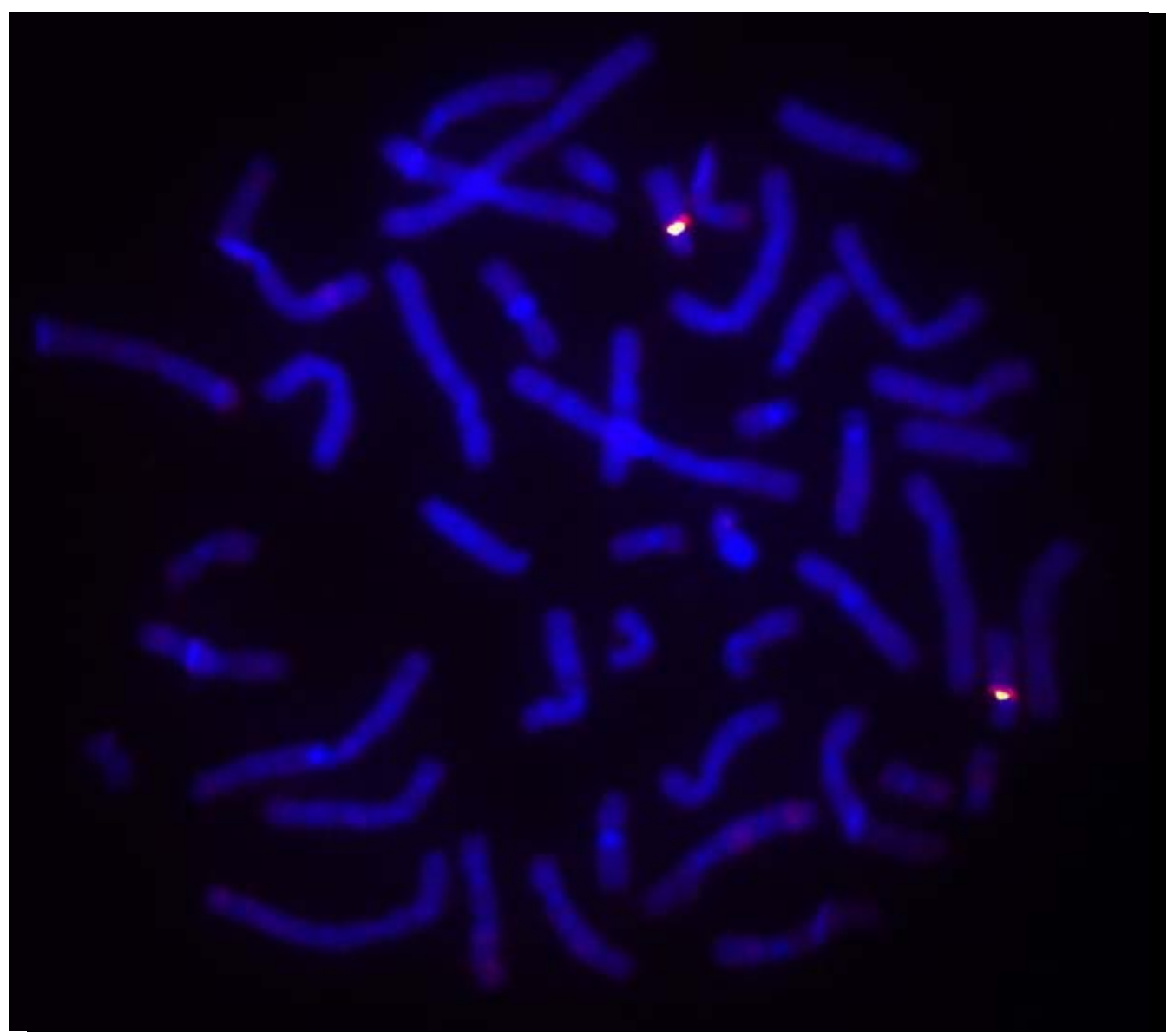

Figura 7. Microfotografia da marcação das sondas de SS18 nas células normais em metáfase. 

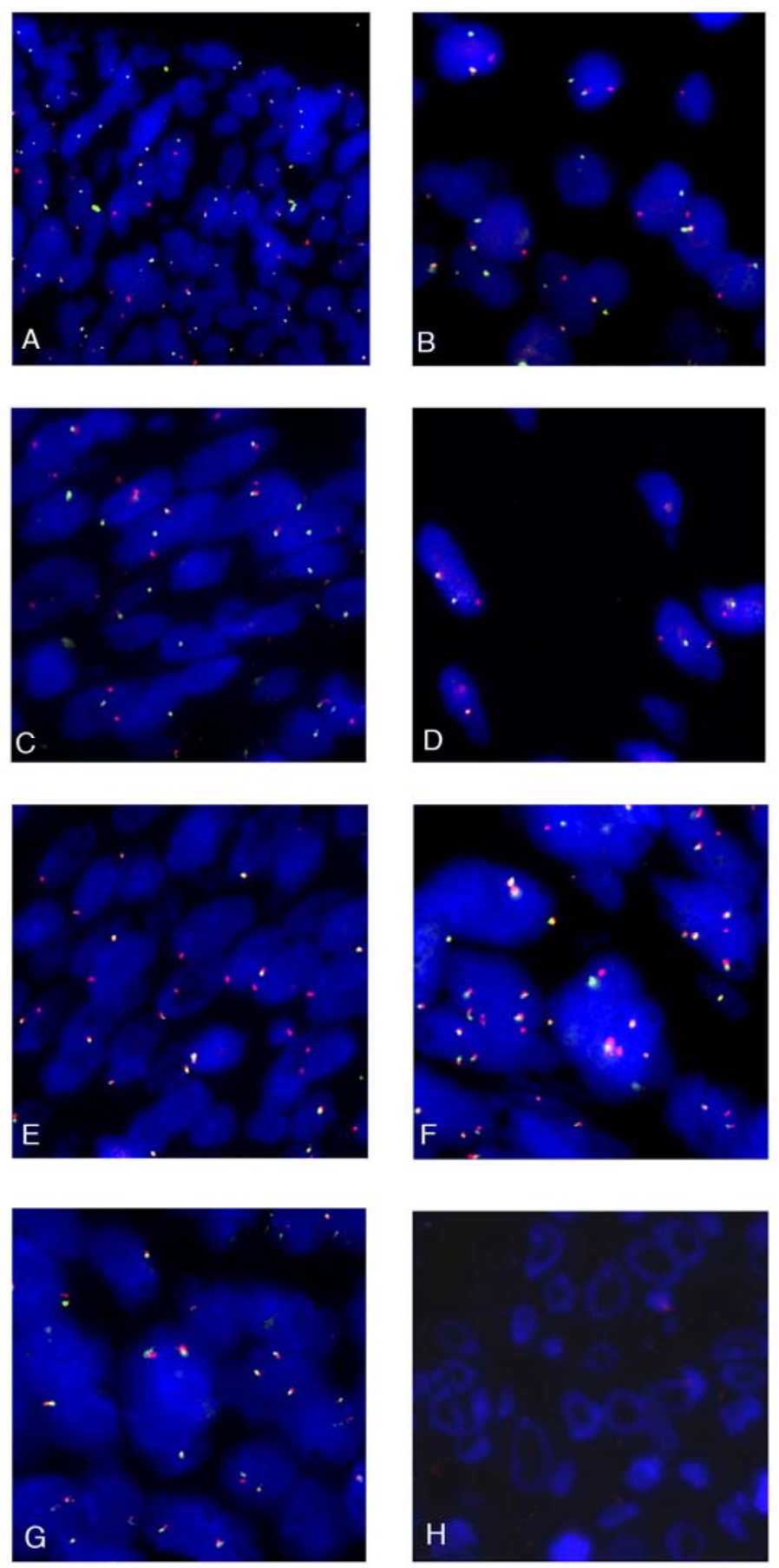

Figura 8. Microfotografia do rearranjo de SS18 por FISH - casos positivos (A); (B); (C); (D); - perda de uma sonda verde (E) - múltiplas cópias de SS18 (F) - caso negativo (G) - ausência de sinal, impróprio para avaliação (H) 


\section{Discussão}

A característica histológica clássica do Sarcoma Sinovial bifásico é bem reconhecida e, geralmente, não oferece grande dificuldade diagnóstica. Mas como tem sido amplamente demonstrado, o subtipo monofásico é mais freqüente $(6 ; 131 ; 132 ; 135 ; 151)$ e nele, a dificuldade diagnóstica deve-se à heterogeneidade histológica e ausência de marcador imuno-histoquímico específico. O diagnóstico diferencial nestes casos pode ser bastante difícil, especialmente quando a análise imuno-histoquímica não revela marcadores de diferenciação epitelial (18;140). O Sarcoma Sinovial pouco diferenciado compartilha similaridades e, portanto, pode ser confundido com diversos tipos de sarcomas e neoplasias malignas não sarcomatosas. Três tipos diferentes de Sarcoma Sinovial pouco diferenciado são descritos, o que amplia ainda mais o espectro de diagnósticos diferenciais atribuídos a esta neoplasia (50). O perfil imuno-histoquímico compartilha similaridades com o perfil de tumores neuroectodérmicos como PNET e TMBNP $(48 ; 56)$.

A diversidade clínica e histológica associada ao Sarcoma Sinovial torna necessário, em casos selecionados, o emprego de técnicas auxiliares para um diagnóstico robusto e acurado. Apesar da morfologia permanecer como "padrão ouro", o uso de uma ou mais técnicas auxiliares para o diagnóstico é reconhecido como de extrema valia na prática da patologia cirúrgica. 
O encontro da fusão SS18-SSX por Reação em Cadeia de Polimerase, transcriptase reversa (RT- PCR) ou por Hibridização in situ (ISH) é considerado uma ferramenta diagnóstica muito poderosa (130;135;141;142). Esta alteração é freqüente, mas não ocorre em 100\% dos casos; no entanto, é um achado unanimemente aceito que suporta integralmente o diagnóstico de Sarcoma Sinovial. A relevância do emprego de técnicas moleculares para o diagnóstico de Sarcoma Sinovial é demonstrada em estudos utilizando técnicas isoladas (130;140).

O uso das técnicas moleculares ou citogenéticas para a determinação desta alteração característica é relevante, não somente para a validação dos casos diagnosticados pelas técnicas convencionais utilizadas em patologia, mas também para a exata classificação e conseqüente tratamento de possíveis casos previamente classificados como neoplasias indiferenciadas ou como outras doenças.

Nosso estudo de 134 tumores, em que o diagnóstico de Sarcoma Sinovial foi considerado o mais provável ou quando Sarcoma Sinovial foi um importante diagnóstico diferencial através da histologia convencional, mostra que os três métodos moleculares analisados - qRT-PCR, RT-PCR convencional e FISH - são valiosos para a detecção do rearranjo de SS18SSX, a marca registrada do Sarcoma Sinovial.

O emprego destes métodos em material parafinado que foi fixado em formalina, ou seja, material de rotina diagnóstica em Anatomia Patológica, 
mostrou-se não somente possível como bastante eficiente. Somente três casos dos 134 analisados não renderam cDNA de qualidade suficiente para o estudo molecular.

Em nossas mãos, a tecnologia mais sensível para a detecção do rearranjo específico do Sarcoma Sinovial foi o qRT-PCR, detectando a fusão SS18-SSX em 126 (96\%) dos 131 casos que possuíam cDNA de qualidade suficiente para avaliação através desta técnica. Através da técnica de RTPCR convencional, detectamos a fusão em 120 (92\%) dos 131 casos analisados.

Quando incluímos os três casos que não renderam cDNA de qualidade suficiente para a técnica de PCR, a sensibilidade para qRT-PCR e RT-PCR convencional torna-se 94\% e 89,5\% respectivamente.

A técnica de FISH foi a menos sensível das três empregadas na detecção do rearranjo gênico no Sarcoma Sinovial. O resultado positivo foi encontrado em 86 (87\%) dos 101 casos estudados no array de tecido. É importante salientar, entretanto, que um dos casos positivos através da técnica de FISH não pode ser analisado por RT-PCR por falta de cDNA de qualidade, demonstrando a utilidade desta técnica na complementação do RT-PCR, especialmente em casos cuja extração do RNA e transcrição reversa não sejam possíveis ou resultem em material insuficiente. 
Adicionam-se à menor sensibilidade do FISH, alguns problemas de interpretação observados em nossa casuística. Foram essencialmente três dificuldades: a primeira, que não havia sido relatada previamente na literatura, foi a detecção de um sinal fusionado (verde e laranja) e um sinal isolado laranja, em mais de $70 \%$ das células neoplásicas. O sinal verde não estava presente nestes casos. Esta variação foi detectada em quatro casos, todos com diagnóstico da presença da fusão SS18-SSX realizado por RTPCR. Foi demonstrada na literatura, a perda da fusão recíproca SSX-SS18 em até dois terços dos casos. Perda esta associada pelos autores à progressão da doença (104). Na nossa visão, a "perda" do segmento gênico marcado pela sonda verde provavelmente é causada pela deleção da fusão recíproca SSX-SS18. Nossa interpretação também se baseia no fato de que a fusão SS18-SSX é composta predominantemente pelo gene SS18. A sonda marcada em laranja (spectrum orange) é complementar à extremidade deste gene na posição 5', enquanto a sonda marcada em verde (spectrum green) é distal à posição 3' marcando, portanto, a fusão recíproca SSX-SS18 após a translocação. Estudos complementares devem todavia ser feitos para a demonstração inequívoca desta teoria.

A segunda dificuldade encontrada na interpretação do FISH para o diagnóstico de Sarcoma Sinovial foi a detecção de múltiplos sinais em alguns casos: este achado pode representar poliploidia ou cópias múltiplas da região marcada pela sonda SYT no cromossomo 18. Este fato foi relatado previamente, não somente em estudos envolvendo o $18 q$, mas também em trabalhos relacionados ao Sarcoma de Ewing / PNET e 
conseqüentemente ao cromossomo 22 (104;152). Em certos casos, os sinais são tão numerosos que resultam em dificuldade de identificação da separação dos sinais verde e laranja. Apesar de numerosos sinais terem, no entanto, sido identificados em 15 casos, em 14 destes pudemos identificar a separação inequívoca dos sinais e, conseqüentemente classificar tais casos como positivos. Em todos estes casos, a interpretação dos resultados do FISH foi apoiada pela positividade do caso através da técnica de RT-PCR.

O terceiro aspecto que precisou ser definido em relação à análise do FISH foi determinar quantas células deveriam ser contadas e qual porcentagem destas células contendo a quebra do sinal seria necessária para que o caso fosse classificado como positivo para o rearranjo do gene SS18. Neste estudo, nós aplicamos os limites definidos por Lu et al. (134); no entanto, não encontramos nenhum caso cuja porcentagem de células contendo sinais separados caiu entre 8 e 21\% das células contadas.

Em casos com contagem limítrofe é importante a confirmação por outro método como o RT-PCR. Mais importante ainda é que cada método e resultado devem ser sempre interpretados em conjunto e correlacionados com dados clínicos, morfológicos e imuno-histoquímicos. Por esta razão acreditamos ser de grande benefício que a interpretação final destas técnicas seja responsabilidade do patologista, por visualização direta das células e correlação com os achados da histologia convencional. 
Nossos resultados demonstram que os primers e as sondas utilizadas nas reações de RT-PCR neste estudo são específicos para os tipos e variantes da fusão SS18-SSX relatados até o momento. A fusão SS18-SSX não foi encontrada em 194 lesões em que o diagnóstico de Sarcoma Sinovial foi excluído, incluindo 109 tumores que possuíam outras translocações e 85 outras lesões ósseas e de tecidos moles em que nenhuma translocação foi detectada. Também encontramos completa concordância entre os resultados de qRT-PCR e RT-PCR convencional usando diferentes pares de primers.

No nosso estudo e em todas as outras séries, com exceção de uma (153), a presença de um dos genes quiméricos SS18-SSX1 ou SS18-SSX2 automaticamente exclui a presença do outro. O mesmo tipo de fusão também persiste nas recidivas e nas lesões metastáticas. Embora consideremos os resultados do grupo de Yang et al (153) sólidos e detalhados, é difícil explicar a possibilidade de duas fusões diferentes envolvendo genes tão semelhantes e localizados na mesma região cromossômica. Além da proximidade de localização cromossômica, os genes SSX1 e SSX2 pertencem à mesma família e compartilham $80 \%$ de homologia em relação à seqüência de pares de base; o desenho dos primers é portanto crucial para que estes dois genes possam ser distinguidos através do PCR.

Em nossa série, seis dos 131 casos avaliados pelas técnicas de RTPCR apresentaram a fusão SS18-SSX detectada por qRT-PCR mas não por 
RT-PCR convencional. Esta diferença revela maior sensibilidade da técnica quantitativa quando comparada à técnica convencional. É necessário, no entanto, interpretar criticamente estes resultados porque parte desta diferença provavelmente é resultado do desenho do primer e / ou do tamanho do produto gerado por estes primers e não resultado da técnica empregada. Quando aplicamos a técnica de RT-PCR convencional com os primers usados na técnica quantitativa, conseguimos positividade em três destes seis casos, sendo possível assim, atribuir ao menos 50\% desta discrepância de sensibilidade aos primers e não à técnica utilizada.

Alguns estudos tentam relacionar o tipo de fusão, SS18-SSX1 ou SS18-SSX2 com o prognóstico ou com a formação de determinado subtipo histológico (Bifásico ou Monofásico), inferindo a influência do tipo de fusão com a ocorrência de diferenciação epitelial. Esta hipótese é sustentada pelo fato de que maioria dos casos bifásicos descritos foram diagnosticados como SS18-SSX1 (119;142). No entanto, até hoje não existe consenso sobre o impacto do tipo de fusão, SS18-SSX1 ou SS18-SSX2, como um fator relevante na diferenciação epitelial ou no prognóstico. O resultado varia entre os autores, sendo por vezes completamente opostos. No estudo multiinstitucional europeu, autores não encontraram relação entre o tipo de fusão e pior prognóstico em ambas as análises: sobrevida sem doença e sobrevida sem metástases (132). Ainda nesta série, contrariando estudos anteriores $(57 ; 117 ; 124 ; 131)$ que apontavam uma tendência de pior prognóstico para pacientes com Sarcoma Sinovial SS18-SSX1, a presença da fusão SS18SSX2 mostrou comportamento mais agressivo . 
Alguns estudos relacionam associação significante entre a presença da fusão SS18-SSX1 e alto índice de proliferação celular (18;102).

A questão "prognóstico" foi acessada por uma série de autores que tentaram dividir o Sarcoma Sinovial em categorias através de grau histológico, subtipos e até mesmo características clínico-patológicas, como tamanho e localização, que seriam determinantes importantes de prognóstico $(16 ; 22 ; 67)$. Na literatura podemos observar uma concordância entre os autores sobre a influência do tamanho do tumor no diagnóstico e a presença de áreas histologicamente pouco diferenciadas como importantes determinantes de prognóstico $(49 ; 64 ; 65 ; 138)$.

Nosso estudo revela que o subtipo bifásico do Sarcoma Sinovial, não raramente apresenta o tipo de fusão SS18-SSX2. Tal achado contraria resultados de séries anteriores, em que a grande maioria dos casos diagnosticados como bifásico continham a fusão SS18-SSX1. Através da meta-análise dos dados publicados na literatura quanto ao tipo de fusão e subtipo histológico, determina-se que a fusão SS18-SSX2 ocorre mais freqüentemente no subtipo monofásico que no bifásico $(p<0.001)$. A metaanálise incluiu um total de 1033 casos, dos quais 314 foram classificados como bifásicos e somente 42 destes possuíam o tipo de fusão SS18-SSX2 (Anexo 1). Esta discrepância pode ser explicada pela baixa freqüência de ambos: subtipo bifásico e tipo de fusão SS18-SSX2 e também pelo fato de que a maioria das casuísticas apresentadas não são numericamente expressivas, pela própria raridade desta neoplasia. 
Apesar da relação entre o subtipo (bifásico ou monofásico) e o tipo de fusão não ter sido estatisticamente significante em nossa série e, mais importante, a presença da fusão SS18-SSX2 não ter sido rara em Sarcoma Sinovial bifásico como previamente reportada, foi intrigante o achado de significância estatística na relação da presença de expressão de citoqueratina e o tipo de fusão SS18-SSX1.

Em nossa série, a relação entre presença de áreas pouco diferenciadas e tipo de fusão não foi significante. Apesar do nosso foco não ter sido a análise do prognóstico, a não associação do tipo de fusão com presença de áreas pouco diferenciadas - este sim, reconhecidamente um importante indicador de prognóstico - indiretamente contraria a associação do tipo de fusão como um determinante da evolução de tais pacientes. Estes resultados, em nossa visão, apóiam o trabalho do grupo de Guillou et al. (132) que consideraram não haver relação entre o tipo de fusão e o prognóstico. Adicionalmente, a grande semelhança estrutural dos dois genes localizados no cromossomo X, SSX1 e SSX2, e freqüentemente envolvidos na fusão com SS18, também deixa pouco provável que tal diferença tenha impacto tão grandioso na evolução. Se esta não influência passar a ser indiscutivelmente comprovada, a importância da determinação destas translocações se firmará como ferramenta diagnóstica e provável alvo terapêutico a ser implementado no futuro.

O presente estudo também ressalta a importância do diagnóstico diferencial entre Mesotelioma e Sarcoma Sinovial, principalmente porque o 
tórax tem sido cada vez mais reconhecido como uma localização não incomum para o Sarcoma Sinovial. A classificação correta destes tumores não somente altera o tratamento mas, no caso do Mesotelioma, a exposição ao asbesto, altamente carcinogênico, pode resultar em sanções legais de caráter indenizatório. Em dois casos de nossa série, a avaliação histopatológica convencional não permitiu a diferenciação entre estes dois tumores pleurais, mesmo quando referidos a patologistas renomados e especializados nestas duas áreas, que consideraram, em ambos os casos, o diagnóstico de Sarcoma Sinovial o mais provável pela histopatologia. A não detecção do rearranjo de SS18 foi importante para excluir o diagnóstico de Sarcoma Sinovial nestes casos.

O terceiro caso pleural foi considerado provavelmente um Tumor Fibroso Solitário negativo para o marcador CD34 e, portanto, a análise molecular foi realizada com o propósito de exclusão do diferencial Sarcoma Sinovial.

Dos dois casos extra pleurais negativos para fusão SS18-SSX, um era localizado na pelve e foi classificado como neoplasia indiferenciada de pequenas células. O segundo era localizado nos tecidos moles próximos à articulação do joelho. Este último, apesar de negativo para a fusão SS18SSX, apresentava características histológicas e imuno-histoquímicas compatíveis com o diagnóstico de Sarcoma Sinovial e este diagnóstico continuou sendo favorecido neste caso. Como é amplamente reconhecido, entretanto, existe uma sobreposição das características histológicas, imuno- 
histoquímicas, bem como em relação à expressão gênica entre o Sarcoma Sinovial e o TMBNP (154;155). TMBNP foi considerado como possível diagnóstico em ambos os casos extra-pleurais. Como nenhum dos pacientes apresentava, todavia, características de neurofibromatose e os tumores não se originavam de grandes nervos, este diagnóstico não pode ser concluído com confiança.

É importante salientar que, se eventos genéticos forem empregados como testes diagnósticos cujo resultado possa incluenciar no tratamento clínico, torna-se crucial o conhecimento da especificidade e sensibilidade do método utilizado. A maioria das evidências publicadas $(129 ; 156)$, incluindo a nossa (157), favorece a especificidade total da detecção do rearranjo do SS18 no Sarcoma Sinovial, apesar de ainda haver algum debate quanto à presença deste rearranjo em tumores com características de TMBNP $(149 ; 150 ; 158)$.

Estabelecer $100 \%$ de sensibilidade é difícil. A sensibilidade da detecção do rearranjo gênico de SS18, no entanto, é alta nos diversos testes como aqui demonstramos, sendo possível atingir cerca de 96\% de sensibilidade. Para que $100 \%$ de sensibilidade fosse alcançada, seria necessário comprovar a natureza dos cinco casos que apresentavam características morfológicas compatíveis com o diagnóstico de Sarcoma Sinovial, mas que foram negativos para o rearranjo de SS18. Um teste realmente robusto para os diagnósticos de TMBNP e Mesotelioma, os principais diferenciais nestes casos, atualmente não existe. Reivindicar, 
portanto, $100 \%$ de sensibilidade pode resultar em um dogma que tende a não ser questionado, posição perigosa para o patologista.

Apesar de termos realizado a pesquisa de todas as variantes da fusão SS18-SSX descritas, a possibilidade da existência de uma nova variante não pode ser completamente excluída. Alternativamente, a não detecção do rearranjo de SS18 pode ser explicada pela completa deleção do cromossomo X, evento já descrito em tumores avançados (138).

Tanto o FISH como os métodos de RT-PCR têm vantagens e desvantagens, mas nosso estudo mostra que estes métodos podem ser complementares. O FISH é geralmente preferido por patologistas, pois estes estão mais familiarizados com a análise das células sob a luz do microscópio do que com a análise de gels. A menos que sondas específicas para cada fusão sejam criadas, o FISH é menos informativo que o RT-PCR. Assim, inicia-se o questionamento: que informações são necessárias a partir dos métodos moleculares? A resposta deve variar em relação aos diversos tipos de tumores e também de acordo com a evolução das pesquisas. Por exemplo, se realmente for demonstrado que o tipo de fusão não altera o prognóstico ou o tratamento dos casos de Sarcoma Sinovial, a identificação das variantes específicas pode tornar-se irrelevante. A avaliação crítica da necessidade dos métodos disponíveis é, portanto, fundamental para que o patologista utilize os recursos de maneira eficiente. 


\section{Conclusões}

- A fixação em formalina e inclusão em parafina, no Sarcoma Sinovial, mostrou-se adequada para análise molecular.

- RT-PCR e FISH são bons métodos para o estudo da fusão SS18-SSX;

- qRT-PCR foi o método mais eficiente na detecção da fusão SS18-SSX, seguido por RT-PCR convencional;

- FISH foi o método menos sensível e menos informativo, porém, pode complementar os outros métodos quando o RNA é de qualidade insuficiente;

- ao analisar o tipo de fusão em relação a presença de áreas pouco diferenciadas, localização ou subtipo histológico nenhuma relação estatisticamente significativa foi observada;

- a fusão SS18-SSX2 em Sarcomas Sinoviais bifásicos não é rara. 


\section{Anexos}

Anexo 1: Meta-análise dos casos positivos para SS18-SSX descritos.

\begin{tabular}{|c|c|c|c|c|c|c|c|c|c|c|}
\hline & \multicolumn{10}{|c|}{ SSX genes envolvidos } \\
\hline Referências & $\begin{array}{l}\text { No } \\
\text { casos }\end{array}$ & $\begin{array}{l}\text { SS18- } \\
\text { SSX+ }\end{array}$ & SSX1 & SSX2 & SSX4 & $\mathrm{MP}$ & $\mathrm{BP}$ & $\mathrm{PD}$ & $\begin{array}{r}\text { BP } \\
\text { SSX1 } \\
\end{array}$ & $\begin{array}{r}\text { BP } \\
\text { SSX2 } \\
\end{array}$ \\
\hline Begueret et al (2005) & 40 & 40 & 22 & 17 & & 24 & 1 & 15 & 1 & 0 \\
\hline Bijwaard et al (2002) & 30 & 29 & 22 & 7 & 0 & 15 & 14 & 0 & 12 & 2 \\
\hline $\begin{array}{l}\text { Crew et al. (1995); } \\
\text { Shipley et al. 1996 }\end{array}$ & 36 & 32 & $21 \mathrm{a}$ & $11 \mathrm{a}$ & 0 & 25 & 7 & 0 & 5 & 2 \\
\hline Gaffney et al (2004) & 11 & 10 & 5 & 5 & 0 & 5 & 5 & 0 & 5 & 0 \\
\hline Guillou et al (2001) & 86 & 77 & 55 & 22 & & 119 & 46 & 38 & 37 & 9 \\
\hline Hill et al (2003) & 25 & 21 & 18 & 3 & 0 & 16 & 5 & 7 & 4 & 1 \\
\hline Hiraga et al. (1998) & 14 & 14 & 10 & 4 & 0 & 11 & 1 & 2 & 1 & 0 \\
\hline $\begin{array}{l}\text { Kawai et al. (1998); } \\
\text { Antonescu (2000b) }\end{array}$ & 73 & 73 & 49 & 24 & 0 & 55 & 18 & 0 & 18 & 0 \\
\hline Lasota et al. (1998) & 21 & 20 & 13 & 7 & 0 & & & & & \\
\hline Lu et al (1999) & 10 & 8 & 6 & 2 & 0 & 5 & 3 & 0 & 3 & 0 \\
\hline Mezzalani et al (2001) & 72 & 72 & 44 & 26 & 2 & 42 & 30 & & 24 & 6 \\
\hline Naito et al (2000) & 18 & 17 & 13 & 7 & 0 & 11 & 9 & & 8 & 1 \\
\hline Nikiforova et al (2005) & 9 & 9 & 6 & 3 & & 6 & 3 & & 3 & 0 \\
\hline Nilsson et al. (1999) & 33 & 33 & 13 & 20 & 0 & 29 & 4 & 0 & 4 & 0 \\
\hline Panagopolous et al (2001) & 54 & 54 & 33 & 20 & 1 & 31 & 9 & 6 & 6 & 3 \\
\hline Tamborini et al (2001) & 59 & 48 & 33 & 16 & 1 & 29 & 19 & 0 & 15 & 4 \\
\hline Thorson et al.(2006) & 22 & 17 & 12 & 5 & & 7 & 10 & & 9 & 1 \\
\hline Tsuji et al. (1998) & 32 & 30 & 22 & 8 & 0 & 23 & 7 & & 6 & 1 \\
\hline Tvrdik at al (2005) & 7 & 7 & 5 & 2 & 0 & 2 & 5 & & 5 & 0 \\
\hline Wei et al (2002) & 37 & 33 & 22 & 6 & & 23 & 10 & & 10 & 0 \\
\hline Willeke et al. (1998) & 10 & 10 & 6 & 5 & 0 & 7 & 3 & & 3 & 0 \\
\hline & & $\begin{array}{l}\quad 654 \\
\text { SS18- }\end{array}$ & 409 & 209 & & 485 & 209 & & $\begin{array}{r}179 \\
\text { BP }\end{array}$ & $\begin{array}{r}30 \\
\mathrm{BP} \\
\mathrm{SCY}\end{array}$ \\
\hline $\begin{array}{l}\text { Multi-institucionais } \\
\text { Ladanyi et al (2002) }\end{array}$ & 243 & $\frac{S S X+}{240}$ & $\begin{array}{r}\text { SSX1 } \\
147\end{array}$ & $\begin{array}{r}\text { SSX2 } \\
91\end{array}$ & $\begin{array}{r}\text { SSX4 } \\
0\end{array}$ & $\begin{array}{l}\text { MP } \\
177\end{array}$ & $\begin{array}{r}\text { BP } \\
59\end{array}$ & $\mathrm{PD}$ & $\begin{array}{r}\text { SSX1 } \\
56\end{array}$ & $\begin{array}{r}\mathrm{SSX} 2 \\
3\end{array}$ \\
\hline Guillon et al (2004) & 165 & 165 & 112 & 53 & & 119 & 46 & & 37 & 9 \\
\hline $\begin{array}{l}\text { Total Geral } \\
\%\end{array}$ & & 1059 & $\begin{array}{r}668 \\
61 \%\end{array}$ & $\begin{array}{r}353 \\
33 \%\end{array}$ & & $\begin{array}{r}781 \\
69 \%\end{array}$ & $\begin{array}{r}314 \\
28 \%\end{array}$ & & $\begin{array}{r}272 \\
87 \%\end{array}$ & $\begin{array}{r}42 \\
13 \%\end{array}$ \\
\hline
\end{tabular}


Anexo 2: Tabela completa dos resultados

\begin{tabular}{|c|c|c|c|c|c|c|c|c|c|}
\hline No & Idade & $\mathrm{S}$ & Localização & Local preciso & $\mathrm{cm}$ & Necrose & Subtipo & $\mathrm{PD}$ & Diag \\
\hline 1 & 33 & $\mathrm{~F}$ & MMII & coxa & 17 & presente & $\mathrm{BI}$ & não & $\mathrm{DP}$ \\
\hline 2 & 71 & $\mathrm{~F}$ & MMII & joelho & 1.5 & presente & MP & $\operatorname{sim}$ & $\mathrm{DD}$ \\
\hline 3 & 52 & $\mathrm{~F}$ & MMII & coxa & 21 & $80 \%$ & MP & $\operatorname{sim}$ & $\mathrm{DP}$ \\
\hline 4 & 44 & $\mathrm{M}$ & MMII & joelho & 9 & focal & $\mathrm{BI}$ & não & $\mathrm{DP}$ \\
\hline 5 & 71 & $\mathrm{~F}$ & MMII & joelho & biopsia & & MP & não & $\mathrm{DP}$ \\
\hline 6 & 31 & $\mathrm{~F}$ & MMII & coxa & 3.5 & - & MP & $\operatorname{sim}$ & $\mathrm{DP}$ \\
\hline 7 & 66 & $M$ & MMSS & antebraço & 9 & presente & MP & não & $\mathrm{DP}$ \\
\hline 8 & 63 & $\mathrm{~F}$ & MMII & perna & 9.5 & focal & MP & $\operatorname{sim}$ & DD \\
\hline 9 & 5 & $\mathrm{~F}$ & Tórax & escapular & 4 & & MP & não & $\mathrm{DP}$ \\
\hline 10 & 37 & $\mathrm{M}$ & MMSS & cotovelo & 10 & presente & MP & $\operatorname{sim}$ & DD \\
\hline 11 & 23 & $\mathrm{M}$ & MMII & joelho & 8.5 & presente & MP & não & $\mathrm{DP}$ \\
\hline 12 & 41 & $M$ & MMII & coxa & biopsia & presente & MP & não & $\mathrm{DP}$ \\
\hline 13 & 41 & $\mathrm{~F}$ & MMII & perna & 17 & $20 \%$ & $\mathrm{BI}$ & $\operatorname{sim}$ & $\mathrm{DP}$ \\
\hline 14 & 44 & M & Tórax & lung & $?$ & & $\mathrm{BI}$ & não & $\mathrm{DP}$ \\
\hline 15 & 29 & $\mathrm{M}$ & MMII & coxa & 14 & $40 \%$ & MP & $\operatorname{sim}$ & $\mathrm{DP}$ \\
\hline 16 & 19 & $\mathrm{~F}$ & MMII & coxa & 7 & $75 \%$ & $\mathrm{BI}$ & não & $\mathrm{DP}$ \\
\hline 17 & 32 & $M$ & MMII & coxa & 13 & presente & MP & $\operatorname{sim}$ & $\mathrm{DP}$ \\
\hline 18 & 26 & $\mathrm{~F}$ & MMII & inguinal & $?$ & presente & MP & $\operatorname{sim}$ & DD \\
\hline 19 & 56 & M & MMSS & braço & 9 & & MP & não & DD \\
\hline 20 & 7 & $M$ & MMII & tornozelo & 3.5 & & $\mathrm{BI}$ & não & $\mathrm{DP}$ \\
\hline 21 & 32 & $\mathrm{M}$ & MMII & coxa & 9 & focal & MP & não & $\mathrm{DP}$ \\
\hline 22 & 22 & $\mathrm{M}$ & Cabeça/ pescoço & maxila & $?$ & & MP & $\operatorname{sim}$ & $\mathrm{DP}$ \\
\hline 23 & 31 & M & MMII & coxa & 7.5 & $>50 \%$ & $\mathrm{BI}$ & não & $\mathrm{DP}$ \\
\hline 24 & 47 & M & MMII & joelho & 7 & presente & MP & não & $\mathrm{DP}$ \\
\hline 25 & 37 & $\mathrm{~F}$ & Tórax & pleural & 2 & & MP & $\operatorname{sim}$ & DD \\
\hline 26 & 30 & $\mathrm{~F}$ & MMII & pé & $?$ & - & MP & não & $\mathrm{DP}$ \\
\hline 27 & 48 & $\mathrm{~F}$ & retroperitônio & perirrenal & 6.5 & presente & MP & não & DD \\
\hline 28 & 27 & $M$ & MMSS & ombro & 7.5 & - & MP & $\operatorname{sim}$ & DD \\
\hline 29 & 42 & $\mathrm{M}$ & MMII & joelho & 10 & focal & MP & $\operatorname{sim}$ & $\mathrm{DP}$ \\
\hline 30 & 25 & $\mathrm{~F}$ & MMII & tornozelo & 8.5 & & $\mathrm{BI}$ & não & $\mathrm{DP}$ \\
\hline 31 & 52 & $\mathrm{~F}$ & MMII & perna & 7.5 & presente & MP & $\operatorname{sim}$ & DD \\
\hline 32 & 44 & $\mathrm{~F}$ & MMII & coxa & 16 & & MP & não & DD \\
\hline 33 & 50 & $\mathrm{~F}$ & MMSS & braço & 7 and 4,5 & $10 \%$ & MP & $\operatorname{sim}$ & $\mathrm{DP}$ \\
\hline 34 & 23 & $\mathrm{~F}$ & MMSS & antebraço & biopsia & & MP & $\operatorname{sim}$ & $\mathrm{DD}$ \\
\hline 35 & 41 & $\mathrm{~F}$ & Tórax & supraclavicular & 8 & & MP & não & $\mathrm{DP}$ \\
\hline 36 & 49 & $\mathrm{~F}$ & MMII & coxa & 6.5 & & MP & não & DD \\
\hline 37 & 60 & $\mathrm{~F}$ & MMII & pé & $?$ & $?$ & MP & não & $\mathrm{DP}$ \\
\hline 38 & 37 & M & Pelvis & pre-sacral & 9.5 & presente & MP & $\operatorname{sim}$ & DD \\
\hline 39 & 22 & M & MMII & coxa & 18 & $>50 \%$ & MP & não & $\mathrm{DP}$ \\
\hline 40 & 52 & M & Tórax & pulmão & $\mathrm{UCH} ?$ & & MP & não & $\mathrm{DP}$ \\
\hline 41 & 11 & M & $?$ & $?$ & $?$ & - & $\mathrm{BI}$ & não & $\mathrm{DP}$ \\
\hline 42 & 81 & $\mathrm{~F}$ & MMII & coxa & 8 & $<50 \%$ & $\mathrm{BI}$ & $\operatorname{sim}$ & $\mathrm{DP}$ \\
\hline 43 & 42 & $\mathrm{M}$ & MMII & joelho & $5.0+3.5$ & & $\mathrm{BI}$ & não & $\mathrm{DP}$ \\
\hline 44 & 50 & M & MMII & inguinal & 2 & & $\mathrm{BI}$ & não & $\mathrm{DP}$ \\
\hline 45 & 21 & $\mathrm{~F}$ & MMII & tornozelo & $?$ & - & MP & não & DP \\
\hline
\end{tabular}




\begin{tabular}{|c|c|c|c|c|c|c|c|c|c|}
\hline No & Idade & $\mathrm{S}$ & Localização & Local preciso & $\mathrm{cm}$ & Necrose & Subtipo & $\mathrm{PD}$ & Diag \\
\hline 46 & 40 & M & $\begin{array}{c}\text { MMII } \\
\text { Cabeca e }\end{array}$ & pé & 5 & & $\mathrm{BI}$ & não & DP \\
\hline 47 & 16 & $M$ & pescoço & submental & $?$ & & MP & não & DD \\
\hline 48 & 41 & $M$ & MMSS & braço & 7 & focal & MP & não & DP \\
\hline 49 & 25 & $\mathrm{~F}$ & MMII & coxa & 3.5 & presente & $\mathrm{BI}$ & não & DP \\
\hline 50 & 38 & M & MMSS & cotovelo & 14 & extensa & MP & não & DP \\
\hline 51 & 22 & $\mathrm{~F}$ & MMII & coxa & 6.5 & $>50 \%$ & MP & $\operatorname{sim}$ & DP \\
\hline 52 & 22 & $\mathrm{~F}$ & MMII & joelho & 1.3 & & MP & não & DP \\
\hline 53 & 27 & $M$ & MMII & pé & $?$ & & MP & não & DP \\
\hline 54 & 44 & $\mathrm{~F}$ & Tórax & pulmão & 11 & & MP & não & DD \\
\hline 55 & 45 & $M$ & Tórax & pleural & $?$ & & MP & $\operatorname{sim}$ & DD \\
\hline 56 & 31 & $M$ & MMII & perna & $?$ & & MP & $\operatorname{sim}$ & DP \\
\hline 57 & 58 & $M$ & $?$ & $?$ & $?$ & & $\mathrm{BI}$ & não & DP \\
\hline 58 & 46 & $M$ & MMSS & mão & fragmentos $12 \mathrm{~g}$ & - & MP & não & DP \\
\hline 59 & 15 & $\mathrm{~F}$ & $\begin{array}{c}\text { MMII } \\
\text { Cabeça e }\end{array}$ & coxa & 21 & $50 \%$ & MP & $\operatorname{sim}$ & DD \\
\hline 60 & 41 & $\mathrm{~F}$ & pescoço & infratemporal & 6 & não & MP & não & DD \\
\hline 61 & 71 & $M$ & Tórax & pleural & $?$ & & $\mathrm{BI}$ & não & DD \\
\hline 62 & 28 & $\mathrm{~F}$ & MMII & pé & 4 & 0 & $\mathrm{BI}$ & não & DP \\
\hline 63 & 45 & $\mathrm{~F}$ & Tórax & pleural & $?$ & $?$ & MP & não & DD \\
\hline 64 & 24 & $M$ & MMSS & braço & 3 & $>50 \%$ & MP & não & DP \\
\hline 65 & 66 & $\mathrm{~F}$ & Tórax & mediastinal & $?$ & & $\mathrm{BI}$ & não & DD \\
\hline 66 & 45 & $\mathrm{~F}$ & MMII & nádega & 16,5 & & MP & $\operatorname{sim}$ & DD \\
\hline 67 & 28 & $\mathrm{~F}$ & MMII & coxa & 2.4 & $<50 \%$ & $\mathrm{BI}$ & não & DP \\
\hline 68 & 30 & $\mathrm{~F}$ & MMII & coxa & 5 & $40 \%$ & MP & não & DP \\
\hline 69 & 18 & M & MMSS & punho & $?$ & $?$ & MP & não & DP \\
\hline 70 & 29 & $\mathrm{~F}$ & $?$ & $?$ & $?$ & $?$ & MP & não & DD \\
\hline 71 & 39 & $M$ & MMSS & antebraço & $?$ & & MP & não & DP \\
\hline 72 & 76 & $\mathrm{~F}$ & MMII & joelho & 12 & presente & MP & $\operatorname{sim}$ & DD \\
\hline 73 & 47 & $\mathrm{~F}$ & MMII & coxa & $?$ & & MP & não & DP \\
\hline 74 & 38 & $\mathrm{~F}$ & retroperitônio & rim & $?$ & presente & MP & $\operatorname{sim}$ & DD \\
\hline 75 & 20 & $M$ & $?$ & $?$ & $?$ & presente & MP & não & DP \\
\hline 76 & 31 & $\mathrm{~F}$ & MMII & perna & 11 & 0 & MP & não & DP \\
\hline 77 & 16 & $\mathrm{~F}$ & MMII & perna & 8,5 & & $\mathrm{BI}$ & não & DP \\
\hline 78 & 43 & $\mathrm{~F}$ & $\begin{array}{c}\text { MMII } \\
\text { Cabeça e }\end{array}$ & perna & 4,2 & não & MP & não & DP \\
\hline 79 & 25 & M & pescoço & supraglote & 1 to $3,5 \times 9$ frag & não & $\mathrm{BI}$ & não & DP \\
\hline 80 & 61 & M & MMSS & antebraço & $?$ & & MP & não & DP \\
\hline 81 & 46 & M & Pelvis & pelvis & 12 & & MP & $\operatorname{sim}$ & DD \\
\hline 82 & 22 & M & MMII & tornozelo & $?$ & & $\mathrm{BI}$ & não & DP \\
\hline 83 & 46 & M & MMII & coxa & 17 & $<50 \%$ & $\mathrm{BI}$ & $\operatorname{sim}$ & DP \\
\hline 84 & 81 & M & MMII & nádega & 25 & & MP & $\operatorname{sim}$ & DD \\
\hline 85 & 24 & M & MMII & tornozelo & fragmentado & presente & MP & $\operatorname{sim}$ & DP \\
\hline 86 & 23 & $\mathrm{~F}$ & MMII & joelho & $\begin{array}{c}3.5 \\
13 \text { fragmentos }\end{array}$ & & MP & não & DP \\
\hline 87 & 19 & M & MMII & joelho & 1,5 to 4,0 & presente & MP & não & DP \\
\hline 88 & 22 & $\mathrm{~F}$ & MMII & coxa & 18 & & $\mathrm{BI}$ & não & DP \\
\hline 89 & 35 & M & MMSS & mão & fragmentos & presente & MP & não & DP \\
\hline 90 & 11 & $M$ & Tórax & Cardíaco & 8 & presente & $\mathrm{BI}$ & $\operatorname{sim}$ & DD \\
\hline
\end{tabular}




\begin{tabular}{|c|c|c|c|c|c|c|c|c|c|}
\hline No & Idade & $\mathrm{S}$ & $\begin{array}{c}\text { Localização } \\
\text { geral }\end{array}$ & Local preciso & $\mathrm{cm}$ & Necrose & Subtipo & $\mathrm{PD}$ & Diag \\
\hline 91 & 25 & $M$ & MMII & tornozelo & fragmentos & presente & $\mathrm{BI}$ & não & DP \\
\hline 92 & 33 & $\mathrm{~F}$ & MMSS & braço & fragmenteos & & MP & não & DP \\
\hline 93 & 21 & $\mathrm{~F}$ & MMII & pé & 7 e 3 & & MP & não & DP \\
\hline 94 & 8 & M & MMII & coxa & $\begin{array}{c}2,4 \text { e } 2,6 \\
\text { fragmentos } 2,5 \text { e }\end{array}$ & & MP & não & DP \\
\hline 95 & 22 & $\mathrm{~F}$ & MMII & pé & 3,0 & presente & MP & $\operatorname{sim}$ & DD \\
\hline 96 & 75 & $\mathrm{~F}$ & MMII & joelho & 10 & presente & MP & $\operatorname{sim}$ & DP \\
\hline 97 & 42 & $M$ & MMSS & ombro & 16 & & MP & não & DD \\
\hline 98 & 23 & M & MMII & tornozelo & 6 & presente & $\mathrm{BI}$ & não & DP \\
\hline 99 & 29 & $M$ & MMII & joelho & fragmentos & presente & MP & $\operatorname{sim}$ & DP \\
\hline 100 & 34 & $M$ & MMII & joelho & 7.5 & & MP & não & $\mathrm{DP}$ \\
\hline 101 & 22 & M & MMII & pé & 13 & presente & $\mathrm{BI}$ & não & DP \\
\hline 102 & 29 & $\mathrm{~F}$ & MMSS & ombro & 6 & presente & MP & $\operatorname{sim}$ & DP \\
\hline 103 & 25 & M & MMII & joelho & 7 & presente & MP & $\operatorname{sim}$ & DP \\
\hline 104 & 32 & $M$ & MMII & coxa & 16 & presente & MP & não & DP \\
\hline 105 & 36 & $\mathrm{~F}$ & MMSS & mão & 5 & presente & MP & não & DP \\
\hline 106 & 44 & $\mathrm{~F}$ & MMII & joelho & 9 & presente & $\mathrm{BI}$ & $\operatorname{sim}$ & DP \\
\hline 107 & 16 & $M$ & MMII & joelho & fragmentos & & MP & $\operatorname{sim}$ & DD \\
\hline 108 & 24 & $M$ & MMSS & antebraço & $\begin{array}{c}18 \\
\text { fragmentos } 0,3 \mathrm{a}\end{array}$ & presente & MP & $\operatorname{sim}$ & DP \\
\hline 109 & 32 & $\mathrm{~F}$ & MMII & pé & 0,8 & presente & MP & $\operatorname{sim}$ & DP \\
\hline 110 & 10 & $M$ & MMII & joelho & 4 e 7 & & MP & não & DP \\
\hline 111 & 25 & $M$ & MMSS & antebraço & 15 & presente & MP & não & DP \\
\hline 112 & 38 & M & MMSS & mão & 6 & & MP & não & DP \\
\hline 113 & 37 & M & MMII & coxa & 13 & presente & MP & não & DP \\
\hline 114 & 31 & $\mathrm{~F}$ & MMII & coxa & 12 & presente & MP & $\operatorname{sim}$ & DP \\
\hline 115 & 12 & M & MMSS & mão & 1.3 & & MP & não & DP \\
\hline 116 & 28 & $\mathrm{~F}$ & MMSS & ombro & 7 & & MP & não & DP \\
\hline 117 & 27 & $\mathrm{~F}$ & MMII & perna & 20 & & MP & $\operatorname{sim}$ & DP \\
\hline 118 & 36 & $M$ & MMII & pé & 8 & zonal & MP & não & DP \\
\hline 119 & 22 & M & MMSS & antebraço & 15 & & MP & não & DP \\
\hline 120 & 25 & M & Tórax & dorsal & Biopsia & & MP & não & DP \\
\hline 121 & 14 & $\mathrm{~F}$ & MMSS & braço & 11 & & $\mathrm{BI}$ & não & DP \\
\hline 122 & 32 & $M$ & MMII & coxa & $?$ & & MP & não & $\mathrm{DD}$ \\
\hline 123 & 47 & $\mathrm{~F}$ & MMII & pé & 11 & $90 \%$ & MP & não & $\mathrm{DP}$ \\
\hline 124 & 30 & $M$ & MMII & coxa & 18 & $35 \%$ & MP & $\operatorname{sim}$ & DP \\
\hline 125 & 68 & $\mathrm{~F}$ & Tórax & pleural & 16 & & MP & não & DD \\
\hline 126 & 20 & $\mathrm{~F}$ & MMII & inguinal & 16 & & $\mathrm{BI}$ & não & $\mathrm{DP}$ \\
\hline 127 & 20 & $M$ & Tórax & pulmão & $?$ & & MP & não & DD \\
\hline 128 & 40 & $\mathrm{~F}$ & Tórax & $\begin{array}{l}\text { pleural } \\
\text { parede }\end{array}$ & Biopsia & & MP & não & DD \\
\hline 129 & 21 & $\mathrm{~F}$ & Tórax & torácica & 3.5 & & MP & não & $\mathrm{DD}$ \\
\hline 130 & 28 & $\mathrm{~F}$ & Tórax & pulmão & 18 & & MP & $\operatorname{sim}$ & DD \\
\hline 131 & 25 & $\mathrm{~F}$ & MMII & perna & 2.5 & & MP & $\operatorname{sim}$ & DP \\
\hline 132 & 30 & $M$ & MMII & tornãozelo & fragmentos 1.5 & & MP & não & DP \\
\hline 133 & 49 & $\mathrm{~F}$ & MMII & pé & 6 & & MP & não & $\mathrm{DP}$ \\
\hline 134 & 34 & $\mathrm{~F}$ & MMII & coxa & fragmentos 7.5 & presente & MP & não & $\mathrm{DP}$ \\
\hline
\end{tabular}




\begin{tabular}{|c|c|c|c|c|c|c|c|c|c|c|}
\hline No & Mitoses & $\mathrm{CK}$ & EMA & bcl-2 & $\mathrm{S} 100$ & CD34 & - & + & Fusão & RT PCR \\
\hline 1 & 12 & - & + & + & - & & $\mathrm{CD} 68$ & CD99 & + & SYT-SSX2 \\
\hline 2 & 21 & + & + & + & - & 0 & & & + & SYT-SSX1 \\
\hline 3 & 21 & + & + & + & + & 0 & & CD99 & + & SYT-SSX1 \\
\hline 4 & 4 & + & + & + & - & + & & CD99 & + & SYT-SSX2 \\
\hline 5 & 2 & + & + & + & - & 0 & Desmina, SMA & CD99 & + & SYT-SSX1 \\
\hline 6 & 31 & + & + & + & - & - & Desmina, SMA & CD99 & + & SYT-SSX1 \\
\hline 7 & 12 & + & 0 & + & + & & Desmina, SMA & & + & SYT-SSX1 \\
\hline 8 & 50 & - & + & + & - & 0 & Desmina, SMA & CD99 & + & SYT-SSX1 \\
\hline 9 & 6 & + & + & + & - & 0 & & & + & SYT-SSX2 \\
\hline 10 & 27 & + & + & - & - & 0 & $\begin{array}{l}\text { Desmina, } \\
\text { SMA, }\end{array}$ & CD99 & + & SYT-SSX1 \\
\hline 11 & 5 & - & + & + & - & 0 & $\begin{array}{l}\text { Desmina, CD3, } \\
\text { SMA, CD99 }\end{array}$ & & + & SYT-SSX1 \\
\hline 12 & 11 & 0 & + & 0 & & & & CD99 & + & SYT-SSX1 \\
\hline 13 & 35 & + & + & + & - & & & CD99 & + & SYT-SSX1 \\
\hline 14 & 3 & + & + & + & + & & & CD99 & + & SYT-SSX1 \\
\hline 15 & 32 & - & + & + & - & - & & CD99 & + & SYT-SSX2 \\
\hline 16 & 10 & + & + & + & - & - & $\begin{array}{l}\text { desmina, SMA, } \\
\text { caldes, caponi }\end{array}$ & CD99 & + & SYT-SSX1 \\
\hline 17 & 50 & + & + & + & - & - & $\begin{array}{l}\text { desmina, SMA, } \\
\text { caldes caponi }\end{array}$ & CD99 & + & SYT-SSX2 \\
\hline 18 & 23 & + & + & + & - & - & & CD99 & + & SYT-SSX2 \\
\hline 19 & 11 & + & + & + & - & - & desmina, SMA & CD99 & + & SYT-SSX1 \\
\hline 20 & 4 & + & + & + & - & - & desmina, SMA & & + & SYT-SSX1 \\
\hline 21 & 8 & + & + & + & - & - & Desmina, SMA & CD99 & + & SYT-SSX1 \\
\hline 22 & 15 & + & + & + & - & & & & + & SYT-SSX2 \\
\hline 23 & 2 & + & + & + & + & & & CD99 & + & SYT-SSX1 \\
\hline 24 & 5 & + & + & + & - & & & & + & SYT-SSX1 \\
\hline 25 & 20 & + & + & + & - & 0 & Desmina, SMA & $\begin{array}{c}\text { CD99 CD56 } \\
\text { synaptophysin }\end{array}$ & + & SYT-SSX1 \\
\hline 26 & 7 & + & + & + & - & - & Desmina, SMA & & + & SYT-SSX1 \\
\hline 27 & 1 & + & + & + & - & - & $\begin{array}{c}\text { desmina, SMA, } \\
\text { CD31 }\end{array}$ & CD99 & + & SYT-SSX1 \\
\hline 28 & 35 & + & + & + & - & 0 & & CD99 & + & SYT-SSX1 \\
\hline 29 & 34 & + & + & + & - & 0 & & CD99 & + & SYT-SSX1 \\
\hline 30 & 4 & + & + & + & - & - & & CD99 SMA & + & SYT-SSX1 \\
\hline 31 & 40 & - & + & - & - & - & Desmina & CD99 SMA & + & SYT-SSX1 \\
\hline 32 & 2 & + & + & + & + & - & $\begin{array}{l}\text { HMB } 45 \\
\text { desmina, }\end{array}$ & CD99 & + & SYT-SSX1 \\
\hline 33 & 22 & - & + & + & + & - & $\begin{array}{l}\text { caldesmon, } \\
\text { SMA } \\
\text { desmina, }\end{array}$ & CD99 & + & SYT-SSX2 \\
\hline 34 & 17 & + & + & + & + & - & $\begin{array}{l}\text { caldesmon, } \\
\text { SMA } \\
\text { desmina, }\end{array}$ & & + & SYT-SSX2 \\
\hline 35 & 15 & + & - & + & - & - & $\begin{array}{l}\text { caldesmon, } \\
\text { SMA }\end{array}$ & CD99 & + & SYT-SSX1 \\
\hline 36 & 19 & + & + & + & - & - & Desmina, SMA & & $\stackrel{+}{\text { POOR }}$ & SYT-SSX1 \\
\hline 37 & 4 & - & + & + & - & - & Desmina, SMA & & RNA & \\
\hline 38 & 52 & + & + & - & + & - & Desmina, SMA & CD99 & -VE & -VE \\
\hline 39 & 11 & + & 0 & + & - & - & SMA & CD99 & + & SYT-SSX1 \\
\hline 40 & 6 & - & + & + & 0 & 0 & & CD99 & + & SYT-SSX2 \\
\hline 41 & 3 & + & + & + & - & - & Desmina, SMA & CD99 & + & SYT-SSX2 \\
\hline 42 & 22 & + & + & + & - & - & Desmina, SMA & & + & SYT-SSX2 \\
\hline 43 & 4 & + & + & + & - & - & Desmina, SMA & & + & SYT-SSX1 \\
\hline 44 & 9 & + & + & + & - & - & SMA, CD31 & & + & SYT-SSX1 \\
\hline 45 & 7 & + & + & + & - & - & Desmina, SMA & & + & SYT-SSX1 \\
\hline
\end{tabular}




\begin{tabular}{|c|c|c|c|c|c|c|c|c|c|c|}
\hline No & Mitoses & $\mathrm{CK}$ & EMA & bcl-2 & S100 & CD34 & & + & Fusão & RT PCR \\
\hline 46 & 21 & + & + & + & - & 0 & & $\mathrm{CD} 99$ & + & SYT-SSX1 \\
\hline 47 & 2 & + & + & + & - & - & Desmina, SMA & CD98 & + & SYT-SSX2 \\
\hline 48 & 20 & - & + & + & - & - & Desmina, SMA & CD99 & + & SYT-SSX2 \\
\hline 49 & 12 & + & + & + & + & - & Desmina, SMA & CD99 & + & SYT-SSX1 \\
\hline 50 & 20 & + & + & + & - & - & Desmina, SMA & CD99 & + & SYT-SSX1 \\
\hline 51 & 51 & - & + & + & - & - & Desmina, SMA & CD99 & + & SYT-SSX2 \\
\hline 52 & 5 & + & + & + & + & 0 & $\begin{array}{l}\text { desmina, } \\
\text { calponin SMA }\end{array}$ & & + & SYT-SSX2 \\
\hline 53 & 1 & - & + & + & + & 0 & & CD99 & + & SYT-SSX2 \\
\hline 54 & 17 & - & + & + & - & - & TTF1 & & + & SYT-SSX1 \\
\hline 55 & 20 & & + & + & - & & & & -VE & -VE \\
\hline 56 & 12 & + & + & + & + & - & Desmina, SMA & CD99 & $-V E$ & $-V E$ \\
\hline 57 & 7 & & + & + & - & - & Desmina, SMA & & + & SYT-SSX2 \\
\hline 58 & 22 & + & + & + & + & 0 & & & + & SYT-SSX2 \\
\hline 59 & 21 & + & + & + & + & - & $\begin{array}{l}\text { desmina, } \\
\text { calponin SMA }\end{array}$ & CD99 & + & SYT-SSX2 \\
\hline 60 & 5 & + & + & + & + & - & $\begin{array}{l}\text { desmina, } \\
\text { calponina SMA } \\
\text { desmina, }\end{array}$ & & + & SYT-SSX1 \\
\hline 61 & & & + & + & + & - & $\begin{array}{l}\text { calponina } \\
\text { SMA }\end{array}$ & & $-V E$ & -VE \\
\hline 62 & 4 & + & + & + & + & - & & & + & SYT-SSX2 \\
\hline 63 & 1 & + & + & + & - & - & & & + & SYT-SSX2 \\
\hline 64 & 19 & + & + & + & + & - & Calponina & CD99 & + & SYT-SSX1 \\
\hline 65 & 3 & 0 & 0 & 0 & 0 & & & & + & SYT-SSX2 \\
\hline 66 & & - & + & + & - & - & Desmina, SMA & $\mathrm{CD} 56$ & + & SYT-SSX2 \\
\hline 67 & 13 & + & + & + & + & - & Desmina, SMA & & + & SYT-SSX1 \\
\hline 68 & 25 & - & + & + & - & - & & CD99 & + & SYT-SSX2 \\
\hline 69 & 2 & + & 0 & + & 0 & - & & CD99 & + & SYT-SSX2 \\
\hline 70 & 2 & & & & & & & & + & SYT-SSX2 \\
\hline 71 & 5 & + & + & + & - & - & SMA & CD99 & + & SYT-SSX2 \\
\hline 72 & 32 & + & + & + & - & - & Desmina, SMA & & + & SYT-SSX2 \\
\hline 73 & 34 & + & + & + & + & - & Desmina, SMA & & + & SYT-SSX2 \\
\hline 74 & 23 & 0 & 0 & 0 & 0 & & & & + & SYT-SSX1 \\
\hline 75 & 12 & 0 & 0 & 0 & 0 & & & & + & SYT-SSX2 \\
\hline 76 & 2 & + & + & + & - & 0 & SMA & & + & SYT-SSX1 \\
\hline 77 & 8 & + & + & + & - & - & Desmina, SMA & & + & SYT-SSX1 \\
\hline 78 & 5 & + & + & + & - & - & & Calponina & + & SYT-SSX2 \\
\hline 79 & 7 & + & + & + & - & - & & & + & SYT-SSX1 \\
\hline 80 & 1 & 0 & + & + & 0 & - & & Calponina & + & SYT-SSX2 \\
\hline 81 & 4 & - & + & + & - & - & SMA, calponin & CD99 & + & SYT-SSX2 \\
\hline 82 & 5 & + & + & + & - & - & SMA, demina & & + & $\mathrm{Neg}$ \\
\hline 83 & 7 & + & + & + & - & - & SMA, demina & CD99 & + & SYT-SSX1 \\
\hline 84 & 6 & + & + & 0 & - & - & SMA, demina & CD99 & + & SYT-SSX2 \\
\hline 85 & 59 & + & + & + & - & - & & & + & SYT-SSX2 \\
\hline 86 & 6 & + & + & + & - & - & SMA, demina & & + & SYT-SSX1 \\
\hline 87 & 8 & + & + & + & - & - & SMA, demina & & + & Neg \\
\hline 88 & 8 & + & + & + & - & - & Desmina, SMA & & + & SYT-SSX1 \\
\hline 89 & 11 & + & + & + & - & - & & & + & SYT-SSX1 \\
\hline 90 & 28 & + & + & + & - & - & & & + & SYT-SSX2 \\
\hline
\end{tabular}




\begin{tabular}{|c|c|c|c|c|c|c|c|c|c|}
\hline No & Mitoses & $\mathrm{CK}$ & EMA & bcl-2 & $\mathrm{S} 100$ & CD34 & & Fusão & RT PCR \\
\hline 91 & 1 & + & + & + & - & - & Desmina, SMA & + & Neg \\
\hline 92 & 25 & - & + & + & + & - & & + & Neg \\
\hline 93 & 3 & + & + & + & - & - & Desmina, SMA & + & SYT-SSX1 \\
\hline 94 & 3 & + & + & + & - & - & Desmina, SMA & + & SYT-SSX1 \\
\hline 95 & 17 & - & + & + & + & - & & + & SYT-SSX1 \\
\hline 96 & 29 & + & + & + & - & - & Desmina, SMA & + & Neg \\
\hline 97 & 2 & + & + & + & - & - & Desmina, SMA & + & SYT-SSX1 \\
\hline 98 & 8 & + & + & + & - & - & Desmina, SMA & - RNA & \\
\hline 99 & 19 & - & + & + & - & - & & + & SYT-SSX1 \\
\hline 100 & 3 & + & + & + & + & - & & + & SYT-SSX1 \\
\hline 101 & 14 & + & + & + & - & - & & + & SYT-SSX2 \\
\hline 102 & 21 & + & + & + & + & - & & + & SYT-SSX1 \\
\hline 103 & 28 & + & + & + & + & - & & + & SYT-SSX1 \\
\hline 104 & 1 & - & + & + & + & - & & + & SYT-SSX1 \\
\hline 105 & 4 & + & + & + & - & - & Desmina, SMA & + & SYT-SSX1 \\
\hline 106 & 22 & + & + & + & - & - & Desmina, SMA & + & SYT-SSX1 \\
\hline 107 & 12 & + & + & + & + & - & & + & Neg \\
\hline 108 & 19 & - & + & + & - & - & Desmina, SMA & + & SYT-SSX2 \\
\hline 109 & 2 & + & + & + & - & - & Desmina, SMA & + & SYT-SSX1 \\
\hline 110 & 6 & + & '+ & + & - & - & Desmina, SMA & + & SYT-SSX1 \\
\hline 111 & 10 & + & + & + & - & - & & + & SYT-SSX1 \\
\hline 112 & 7 & + & + & + & - & - & Desmina, SMA & + & SYT-SSX1 \\
\hline 113 & 6 & + & + & + & - & - & Desmina, SMA & + & SYT-SSX1 \\
\hline 114 & 34 & - & + & + & + & - & & + & SYT-SSX2 \\
\hline 115 & 2 & + & + & + & - & - & & + & SYT-SSX1 \\
\hline 116 & 7 & + & + & + & - & - & Desmina, SMA & + & SYT-SSX2 \\
\hline 117 & 26 & + & + & + & - & - & Desmina, SMA & + & SYT-SSX2 \\
\hline 118 & 2 & - & + & + & + & - & & + & SYT-SSX1 \\
\hline 119 & 6 & + & + & + & - & - & & + & SYT-SSX2 \\
\hline 120 & 1 & + & + & + & - & - & Desmina, SMA & + & SYT-SSX2 \\
\hline 121 & 8 & + & + & + & - & & & $\stackrel{+}{\mathrm{POOR}}$ & SYT-SSX1 \\
\hline 122 & 2 & + & + & + & - & - & & RNA & \\
\hline 123 & 5 & + & + & + & - & & Desmina & + & SYT-SSX2 \\
\hline 124 & 18 & + & + & + & - & - & & + & SYT-SSX2 \\
\hline 125 & 1 & - & + & 0 & - & - & & $-V E$ & $-V E$ \\
\hline 126 & 1 & + & + & + & - & - & Desmina, SMA & + & SYT-SSX1 \\
\hline 127 & 11 & + & + & + & - & & & + & SYT-SSX2 \\
\hline 128 & 2 & + & + & + & - & & & + & SYT-SSX2 \\
\hline 129 & 15 & + & + & + & - & & & + & SYT-SSX1 \\
\hline 130 & 14 & + & + & + & - & & & + & SYT-SSX2 \\
\hline 131 & 21 & + & + & + & - & - & Desmina, SMA & + & SYT-SSX1 \\
\hline 132 & 9 & - & + & + & - & & & + & SYT-SSX2 \\
\hline 133 & 17 & + & + & + & - & & & + & SYT-SSX1 \\
\hline 134 & 18 & + & + & + & - & & & + & SYT-SSX1 \\
\hline
\end{tabular}




\begin{tabular}{|c|c|c|c|c|c|c|}
\hline No & qRT-PCR & RE Xmn I & $\mathrm{FISH}$ & $\%$ & Obs FISH & G6PD \\
\hline 1 & SYT-SSX & & + & $70 \%$ & cópias múltiplas & 2 \\
\hline 2 & SYT-SSX & & + & $70 \%$ & cópias múltiplas & 2 \\
\hline 3 & SYT-SSX & SSX1 & + & $58 \%$ & & 2 \\
\hline 4 & SYT-SSX & & + & $52 \%$ & & 2 \\
\hline 5 & SYT-SSX & & + & $50 \%$ & sinais fracos & 2 \\
\hline 6 & SYT-SSX & SSX1 & + & $56 \%$ & cópias múltiplas & 2 \\
\hline 7 & SYT-SSX & & + & $58 \%$ & & 2 \\
\hline 8 & SYT-SSX & & + & $54 \%$ & cópias múltiplas & 2 \\
\hline 9 & SYT-SSX & & + & $42 \%$ & sinais fracos & 2 \\
\hline 10 & SYT-SSX & & negativo & $6 \%$ & fusão + laranja & 2 \\
\hline 11 & SYT-SSX & & + & $54 \%$ & & 2 \\
\hline 12 & SYT-SSX & & não realizado & não bloco & & 2 \\
\hline 13 & SYT-SSX & & + & $74 \%$ & cópias múltiplas & 2 \\
\hline 14 & SYT-SSX1 & SSX1 & + & $62 \%$ & sinais fracos & 2 \\
\hline 15 & SYT-SSX & & + & $62 \%$ & cópias múltiplas & 2 \\
\hline 16 & SYT-SSX & & + & $54 \%$ & & 2 \\
\hline 17 & SYT-SSX & & + & $72 \%$ & & 2 \\
\hline 18 & SYT-SSX & & + & $56 \%$ & & 2 \\
\hline 19 & SYT-SSX & & + & $50 \%$ & & 2 \\
\hline 20 & SYT-SSX & SSX1 & não sinal & não sinal & & 2 \\
\hline 21 & SYT-SSX1 & & + & $50 \%$ & poucas cels & 2 \\
\hline 22 & SYT-SSX2 & & + & $57 \%$ & sinais fracos & 2 \\
\hline 23 & SYT-SSX & & + & $70 \%$ & & 2 \\
\hline 24 & SYT-SSX & SSX1 & + & $58 \%$ & cópias múltiplas & 2 \\
\hline 25 & SYT-SSX & SSX1 & não realizado & não bloco & & 3 \\
\hline 26 & SYT-SSX1 & SSX1 & + & $58 \%$ & & \\
\hline 27 & SYT-SSX & & + & $36 \%$ & & 2 \\
\hline 28 & SYT-SSX & & + & $66 \%$ & & 2 \\
\hline 29 & SYT-SSX & & + & $62 \%$ & cópias múltiplas & 2 \\
\hline 30 & SYT-SSX & & + & $36 \%$ & & 2 \\
\hline 31 & SYT-SSX & & $\begin{array}{c}\text { negativo } \\
\text { não realizado }\end{array}$ & $0 \%$ & negativo & 2 \\
\hline 32 & SYT-SSX & & & não bloco & & 2 \\
\hline 33 & SYT-SSX2 & SSX2 & + & $70 \%$ & & 2 \\
\hline 34 & SYT-SSX2 & SSX2 & + & $34 \%$ & cópias múltiplas & 3 \\
\hline 35 & SYT-SSX & & + & $72 \%$ & cópias múltiplas & 3 \\
\hline 36 & SYT-SSX & & + & $42 \%$ & & 3 \\
\hline 37 & & & não sinal & não sinal & & 0 \\
\hline 38 & negativo & & negativo & $0 \%$ & & 3 \\
\hline 39 & SYT-SSX & & + & $61 \%$ & & 3 \\
\hline 40 & SYT-SSX2 & SSX2 & $\stackrel{+}{+}$ não realizado & $66 \%$ & & 2 \\
\hline 41 & SYT-SSX & SSX2 & & não bloco & & 3 \\
\hline 42 & SYT-SSX & & + & $58 \%$ & & 3 \\
\hline 43 & SYT-SSX & & + & $74 \%$ & cópias múltiplas & 3 \\
\hline 44 & SYT-SSX & & 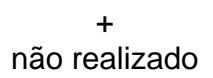 & $58 \%$ & sinais fracos & 3 \\
\hline 45 & SYT-SSX & & & não bloco & & 3 \\
\hline
\end{tabular}




\begin{tabular}{|c|c|c|c|c|c|c|}
\hline No & qRT-PCR & RE Xmn I & $\mathrm{FISH}$ & $\%$ & Obs FISH & G6PD \\
\hline 46 & SYT-SSX & & + & $68 \%$ & & 3 \\
\hline 47 & SYT-SSX & & + & $48 \%$ & cópias múltiplas & 3 \\
\hline 48 & SYT-SSX & & + & $40 \%$ & & 2 \\
\hline 49 & SYT-SSX & & + & $62 \%$ & & 3 \\
\hline 50 & SYT-SSX & & + & $58 \%$ & & 3 \\
\hline 51 & SYT-SSX & & negativo & $2 \%$ & negativo & 3 \\
\hline 52 & SYT-SSX & & não realizado & não bloco & & 3 \\
\hline 53 & SYT-SSX & & não realizado & não bloco & & 3 \\
\hline 54 & SYT-SSX & & + & $54 \%$ & & 2 \\
\hline 55 & negativo & & negativo & $0 \%$ & & 3 \\
\hline 56 & negativo & & negativo & $0 \%$ & & 3 \\
\hline 57 & SYT-SSX & & + & $60 \%$ & & 2 \\
\hline 58 & SYT-SSX & & não realizado & não bloco & & 3 \\
\hline 59 & SYT-SSX & & + & $46 \%$ & sinais fracos & 3 \\
\hline 60 & SYT-SSX & & + & $52 \%$ & sinais fracos & 3 \\
\hline 61 & negativo & & negativo & $0 \%$ & & 3 \\
\hline 62 & SYT-SSX & & + & $56 \%$ & & 3 \\
\hline 63 & SYT-SSX & & + & $42 \%$ & sinais fracos & 3 \\
\hline 64 & SYT-SSX & SSX1 & negativo & $8 \%$ & cópias & 3 \\
\hline 65 & SYT-SSX & & não realizado & $\begin{array}{c}\text { não bloco } \\
\text { Não }\end{array}$ & & 1 \\
\hline 66 & SYT-SSX & & não realizado & material & & 3 \\
\hline 67 & SYT-SSX & & + & $52 \%$ & & 3 \\
\hline 68 & SYT-SSX & & + & $\begin{array}{l}50 \% \\
\text { não }\end{array}$ & cópias múltiplas & 3 \\
\hline 69 & SYT-SSX & & não realizado & material & & 3 \\
\hline 70 & SYT-SSX & & não realizado & não bloco & & 3 \\
\hline 71 & SYT-SSX & & não realizado & não bloco & & 3 \\
\hline 72 & SYT-SSX & & negativo & $2 \%$ & fusão + laranja 47 & 2 \\
\hline 73 & SYT-SSX & & não realizado & Não bloco & negativo & 2 \\
\hline 74 & SYT-SSX & & não realizado & não bloco & & 3 \\
\hline 75 & SYT-SSX & & não realizado & não bloco & & 1 \\
\hline 76 & SYT-SSX & & não realizado & Nao mat. & & 3 \\
\hline 77 & SYT-SSX & & + & $56 \%$ & sinais fracos & 3 \\
\hline 78 & SYT-SSX & & negativo & $4 \%$ & fusão + laranja & 3 \\
\hline 79 & SYT-SSX & & + & $60 \%$ & & 3 \\
\hline 80 & SYT-SSX & & não realizado & não bloco & & 3 \\
\hline 81 & SYT-SSX & & + & $58 \%$ & & 2 \\
\hline 82 & SYT-SSX & SSX2 & negativo & $4 \%$ & & 1 \\
\hline 83 & SYT-SSX & & + & $48 \%$ & & 3 \\
\hline 84 & SYT-SSX & & + & $64 \%$ & & 2 \\
\hline 85 & SYT-SSX & & + & $56 \%$ & & 1 \\
\hline 86 & SYT-SSX & & + & $50 \%$ & & 1 \\
\hline 87 & SYT-SSX & & não sinal & não sinal & & 1 \\
\hline 88 & SYT-SSX & & + & $\begin{array}{c}56 \% \\
\text { não sinal }\end{array}$ & & 2 \\
\hline 89 & SYT-SSX & & não sinal & & & 0 \\
\hline 90 & SYT-SSX & & + & $68 \%$ & & 0 \\
\hline
\end{tabular}




\begin{tabular}{|c|c|c|c|c|c|c|}
\hline No & qRT-PCR & RE Xmn I & $\mathrm{FISH}$ & $\%$ & Obs FISH & G6PD \\
\hline 91 & SYT-SSX2 & SSX2 & não realizado & $\begin{array}{c}\text { não } \\
\text { material }\end{array}$ & & 1 \\
\hline 92 & SYT-SSX & SSX1 & não realizado & não core & & 1 \\
\hline 93 & SYT-SSX & & + & $72 \%$ & & 1 \\
\hline 94 & SYT-SSX & & negativo & $2 \%$ & cópias múltiplas & 1 \\
\hline 95 & SYT-SSX & & + & $54 \%$ & & 1 \\
\hline 96 & SYT-SSX & & não sinal & não sinal & & 1 \\
\hline 97 & SYT-SSX & & + & $60 \%$ & & 1 \\
\hline 98 & & & + & $52 \%$ & & 0 \\
\hline 99 & SYT/SSX & & + & $62 \%$ & & 1 \\
\hline 100 & SYT-SSX & & + & $50 \%$ & & 2 \\
\hline 101 & SYT-SSX & SSX2 & não realizado & não core & & 2 \\
\hline 102 & SYT-SSX & & + & $64 \%$ & & 0 \\
\hline 103 & SYT-SSX & & + & $66 \%$ & & 0 \\
\hline 104 & SYT-SSX & & + & $68 \%$ & & 1 \\
\hline 105 & SYT-SSX & & + & $60 \%$ & & 1 \\
\hline 106 & SYT-SSX & & + & $\begin{array}{l}63 \% \\
\text { não }\end{array}$ & & 2 \\
\hline 107 & SYT-SSX & & não realizado & material & & 1 \\
\hline 108 & SYT-SSX & & não sinal & não sinal & & 1 \\
\hline 109 & SYT-SSX & & + & $62 \%$ & & 2 \\
\hline 110 & SYT-SSX & & + & $21 \%$ & sinais fracos & 1 \\
\hline 111 & SYT-SSX & & + & $68 \%$ & cópias múltiplas & 2 \\
\hline 112 & SYT-SSX & & + & $54 \%$ & & 1 \\
\hline 113 & SYT-SSX & & + & $48 \%$ & & 0 \\
\hline 114 & SYT-SSX & & + & $\begin{array}{l}56 \% \\
\text { não }\end{array}$ & & 1 \\
\hline 115 & SYT-SSX & SSX1 & não realizado & material & & 2 \\
\hline 116 & SYT-SSX & & + & $34 \%$ & & 2 \\
\hline 117 & SYT-SSX & & + & $56 \%$ & & 1 \\
\hline 118 & SYT-SSX & & + & $58 \%$ & & 1 \\
\hline 119 & SYT-SSX & & + & $42 \%$ & & 2 \\
\hline 120 & SYT-SSX & & + & $54 \%$ & & 2 \\
\hline 121 & SYT-SSX & & + & $62 \%$ & & 2 \\
\hline 122 & negativo & & não realizado & não core & & 0 \\
\hline 123 & SYT-SSX & & + & $60 \%$ & & 2 \\
\hline 124 & SYT-SSX & & negativo & $0 \%$ & negativo & \\
\hline 125 & negativo & & negativo & $0 \%$ & poucas cels & 2 \\
\hline 126 & SYT-SSX & SSX1 & + & $58 \%$ & & 2 \\
\hline 127 & SYT-SSX & SSX2 & + & $58 \%$ & & \\
\hline 128 & SYT-SSX & SSX2 & + & $48 \%$ & & \\
\hline 129 & SYT-SSX & SSX1 & + & $67 \%$ & & 0 \\
\hline 130 & SYT-SSX & & + & $52 \%$ & & 0 \\
\hline 131 & SYT-SSX & & não realizado & não core & & 0 \\
\hline 132 & SYT-SSX & & não sinal & não sinal & & 0 \\
\hline 133 & SYT-SSX & & + & $60 \%$ & & 1 \\
\hline 134 & SYT-SSX & & não sinal & não sinal & & 1 \\
\hline
\end{tabular}




$\begin{array}{ll}\text { Legenda do Anexo 2: } \\ \text { MMII } & \text { Membro inferior } \\ \text { MMSS } & \text { Membro superior } \\ \text { DD } & \text { Sarcoma sinovial foi um diagnóstico diferencial importante } \\ \text { DP } & \text { Sarcoma sinovial foi o principal diagnóstico } \\ \text { Mitoses } & N^{0} \text { de mitoses / 10 CGA } \\ \text { Fusão } & \text { Positivo ou negativo para rearranjo por qualquer método } \\ \text { - } & \text { Reações imuno-histoquímica adicionais negativas } \\ + & \text { Reações imuno-histoquímica adicionais postivas } \\ \text {-VE / neg } & \text { Negativo } \\ \text { Poor RNA } & \text { RNA de qualidade insuficiente } \\ \text { G6PD 1 } & \text { geração de produto de até } 86 \text { pb } \\ \text { G6PD 2 } & \text { geração de produto de até } 141 \text { pb } \\ \text { G6PD 3 } & \text { geração de produto de até } 200 \text { pb } \\ \text { SYT-SSX } & \text { SS18-SSX } \\ \text { SYT-SSX1 } & \text { SS18-SSX1 } \\ \text { SYT-SSX2 } & \text { SS18-SSX2 }\end{array}$




\section{Referências}

(1) Buck P, Mickelson MR, Bonfiglio M. Synovial sarcoma: a review of 33 cases. Clin Orthop Relat Res 1981 May;(156):211-5.

(2) Cameron HU, Kostuik JP. A long-term follow-up of synovial sarcoma. J Bone Joint Surg Br 1974 Nov;56-B(4):613-7.

(3) Gerner RE, Moore GE. Synovial sarcoma. Ann Surg 1975 Jan;181(1):22-5.

(4) Lopes JM, Hannisdal E, Bjerkehagen B, Bruland OS, Danielsen HE, Pettersen EO, et al. Synovial sarcoma. Evaluation of prognosis with emphasis on the study of DNA ploidy and proliferation (PCNA and Ki-67) markers. Anal Cell Pathol 1998;16(1):45-62.

(5) Weiss SW, Goldblum JR. Synovial Sarcoma. In: Weiss SW, Goldblum JR, editors. Enzinger and Weiss's Soft Tissue Tumors. 4th ed. Mosby; 2001. p. 309-46.

(6) Fisher C. Synovial sarcoma. Ann Diagn Pathol 1998 Dec;2(6):401-21.

(7) Fisher C, Folpe AL, Hashimoto H, Weiss SW. Intra-abdominal synovial sarcoma: a clinicopathological study. Histopathology 2004 Sep;45(3):24553.

(8) Gaertner E, Zeren EH, Fleming MV, Colby TV, Travis WD. Biphasic synovial sarcomas arising in the pleural cavity. A clinicopathologic study of five cases. Am J Surg Pathol 1996 Jan;20(1):36-45.

(9) Nicholson AG, Rigby M, Lincoln C, Meller S, Fisher C. Synovial sarcoma of the heart. Histopathology 1997 Apr;30(4):349-52.

(10) Nicholson AG, Goldstraw P, Fisher C. Synovial sarcoma of the pleura and its differentiation from other primary pleural tumours: a clinicopathological and immunohistochemical review of three cases. Histopathology 1998 Dec;33(6):508-13.

(11) O'donnell P, Diss TC, Whelan J, Flanagan AM. Synovial sarcoma with radiological appearances of primitive neuroectodermal tumour/Ewing sarcoma: differentiation by molecular genetic studies. Skeletal Radiol 2006 Apr;35(4):233-9.

(12) Cadman NL, Soule EH, Kelly PJ. Synovial Sarcoma; an Analysis of 34 Tumors. Cancer 1965 May;18:613-27.

(13) Weiss SW, Goldblum JR. Soft Tissue Tumors. In: Weiss SW, Goldblum JR, editors. Enzinger and Weiss's Soft Tissue Tumors. 4th ed. Mosby; 2001.

(14) Wright $\mathrm{PH}$, Sim $\mathrm{FH}$, Soule EH, Taylor WF. Synovial sarcoma. J Bone Joint Surg Am 1982 Jan;64(1):112-22. 
(15) Knox LC. Synovial Sarcoma. Am J Cancer 1936;28:461-8.

(16) Bergh P, Meis-Kindblom JM, Gherlinzoni F, Berlin O, Bacchini P, Bertoni F, et al. Synovial sarcoma: identification of low and high risk groups. Cancer 1999 Jun 15;85(12):2596-607.

(17) Cagle LA, Mirra JM, Storm FK, Roe DJ, Eilber FR. Histologic features relating to prognosis in synovial sarcoma. Cancer 1987 May 15;59(10):1810-4.

(18) Inagaki H, Nagasaka T, Otsuka T, Sugiura E, Nakashima N, Eimoto T. Association of SYT-SSX fusion types with proliferative activity and prognosis in synovial sarcoma. Mod Pathol 2000 May;13(5):482-8.

(19) Oda Y, Hashimoto H, Takeshita S, Tsuneyoshi M. The prognostic value of immunohistochemical staining for proliferating cell nuclear antigen in synovial sarcoma. Cancer 1993 Jul 15;72(2):478-85.

(20) Oda Y, Hashimoto H, Tsuneyoshi M, Takeshita S. Survival in synovial sarcoma. A multivariate study of prognostic factors with special emphasis on the comparison between early death and long-term survival. Am J Surg Pathol 1993 Jan;17(1):35-44.

(21) Singer S, Baldini EH, Demetri GD, Fletcher JA, Corson JM. Synovial sarcoma: prognostic significance of tumor size, margin of resection, and mitotic activity for survival. J Clin Oncol 1996 Apr;14(4):1201-8.

(22) Skytting B, Meis-Kindblom JM, Larsson O, Virolainen M, Perfekt R, Akerman M, et al. Synovial sarcoma--identification of favorable and unfavorable histologic types: a Scandinavian sarcoma group study of 104 cases. Acta Orthop Scand 1999 Dec;70(6):543-54.

(23) Coindre JM, Terrier P, Bui NB, Bonichon F, Collin F, Le D, V, et al. Prognostic factors in adult patients with locally controlled soft tissue sarcoma. A study of 546 patients from the French Federation of Cancer Centers Sarcoma Group. J Clin Oncol 1996 Mar;14(3):869-77.

(24) Jensen OM, Hogh J, Ostgaard SE, Nordentoft AM, Sneppen O. Histopathological grading of soft tissue tumours. Prognostic significance in a prospective study of 278 consecutive cases. J Pathol 1991 Jan;163(1):19-24.

(25) Choong PF, Pritchard DJ, Rock MG, Sim FH, Frassica FJ. Survival after pulmonary metastasectomy in soft tissue sarcoma. Prognostic factors in 214 patients. Acta Orthop Scand 1995 Dec;66(6):561-8.

(26) Choong PF, Gustafson P, Willen H, Akerman M, Baldetrop B, Ferno M, et al. Prognosis following locally recurrent soft-tissue sarcoma. A staging system based on primary and recurrent tumour characteristics. Int $\mathrm{J}$ Cancer 1995 Jan 3;60(1):33-7.

(27) Skytting BT, Bauer HC, Perfekt R, Huuhtanen R, Alvegard TA, Berlin O, et al. Clinical course in synovial sarcoma: a Scandinavian sarcoma group study of 104 patients. Acta Orthop Scand 1999 Dec;70(6):536-42. 
(28) Lewis JJ, Antonescu CR, Leung DH, Blumberg D, Healey JH, Woodruff $\mathrm{JM}$, et al. Synovial sarcoma: a multivariate analysis of prognostic factors in 112 patients with primary localized tumors of the extremity. J Clin Oncol 2000 May;18(10):2087-94.

(29) Ryan JR, Baker LH, Benjamin RS. The natural history of metastatic synovial sarcoma: experience of the Southwest Oncology group. Clin Orthop Relat Res 1982 Apr;(164):257-60.

(30) Skytting BT, Bauer HC, Larsson O. Diagnosis, treatment and prognosis of patients with synovial sarcoma. The Scandinavian Sarcoma Group experience. Acta Orthop Scand Suppl 1999 Jun;285:47-9.

(31) Ladenstein R, Treuner J, Koscielniak E, d'Oleire F, Keim M, Gadner H, et al. Synovial sarcoma of childhood and adolescence. Report of the German CWS-81 study. Cancer 1993 Jun 1;71(11):3647-55.

(32) Ferrari A, Gronchi A, Casanova M, Meazza C, Gandola L, Collini P, et al. Synovial sarcoma: a retrospective analysis of 271 patients of all ages treated at a single institution. Cancer 2004 Aug 1;101(3):627-34.

(33) Fontanesi J, Pappo AS, Parham DM, Hurwitz CA, Rao BN, Luo X, et al. Role of irradiation in management of synovial sarcoma: St. Jude Children's Research Hospital experience. Med Pediatr Oncol 1996 Apr;26(4):264-7.

(34) Wolden SL. Radiation therapy for non-rhabdomyosarcoma soft tissue sarcomas in adolescents and young adults. J Pediatr Hematol Oncol 2005 Apr;27(4):212-4.

(35) Rosen G, Forscher C, Lowenbraun S, Eilber F, Eckardt J, Holmes C, et al. Synovial sarcoma. Uniform response of metastases to high dose ifosfamide. Cancer 1994 May 15;73(10):2506-11.

(36) Spurrell EL, Fisher C, Thomas JM, Judson IR. Prognostic factors in advanced synovial sarcoma: an analysis of 104 patients treated at the Royal Marsden Hospital. Ann Oncol 2005 Mar;16(3):437-44.

(37) Mackenzie DH. Synovial sarcoma. A review of 58 cases. Cancer 1966 Feb;19(2):169-80.

(38) Enzinger FM, Latters R, Torloni $\mathrm{H}$. Histological typing of soft tissue tumors. World Health Organization; 1969.

(39) WEISS S. Histological Typing of Soft Tissue Tumors. 2nd ed. New York, Springer-Verlag, World Health Organization; 1994.

(40) Fletcher CD, Unni KK, Mertens F. Pathology \& Genetics of Tumours of Soft Tissue and Bone. Lyon: IARC Press, World Health Organization; 2002.

(41) Fisher C. Synovial sarcoma: ultrastructural and immunohistochemical features of epithelial differentiation in monophasic and biphasic tumors. Hum Pathol 1986 Oct;17(10):996-1008. 
(42) Smith ME, Fisher C, Wilkinson LS, Edwards JC. Synovial sarcoma lack synovial differentiation. Histopathology 1995 Mar;26(3):279-81.

(43) Tsuneyoshi M, Yokoyama K, Enjoji M. Synovial sarcoma. A clinicopathologic and ultrastructural study of 42 cases. Acta Pathol Jpn 1983 Jan;33(1):23-36.

(44) Edwards JC. The synovial lining--a movable feast. Br J Rheumatol 1989 Dec;28(6):534-6.

(45) Edwards MC, Evans FJ, Barrett ML, Gordon D. Structural correlations of phorbol-ester-induced stimulation of PGE2 production by human rheumatoid synovial cells. Inflammation 1985 Mar;9(1):33-8.

(46) Stravino VD. The synovial system. Am J Phys Med 1972 Dec;51(6):31220.

(47) Wilkinson LS, Pitsillides AA, Worrall JG, Edwards JC. Light microscopic characterization of the fibroblast-like synovial intimal cell (synoviocyte). Arthritis Rheum 1992 Oct;35(10):1179-84.

(48) Folpe AL, Schmidt RA, Chapman D, Gown AM. Poorly differentiated synovial sarcoma: immunohistochemical distinction from primitive neuroectodermal tumors and high-grade malignant peripheral nerve sheath tumors. Am J Surg Pathol 1998 Jun;22(6):673-82.

(49) Machen SK, Easley KA, Goldblum JR. Synovial sarcoma of the extremities: a clinicopathologic study of 34 cases, including semiquantitative analysis of spindled, epithelial, and poorly differentiated areas. Am J Surg Pathol 1999 Mar;23(3):268-75.

(50) Meis-Kindblom JM, Stenman G, Kindblom LG. Differential diagnosis of small round cell tumors. Semin Diagn Pathol 1996 Aug;13(3):213-41.

(51) Tajima K, Fuyama S, Yamaguchi H, Ohrui H, Suzuki K, Akiba J, et al. Pure monophasic, epithelial synovial sarcoma without a spindle cell component. Histopathology 1999 Jan;34(1):78-81.

(52) van de RM, Barr FG, Xiong QB, Hedges M, Shipley J, Fisher C. Poorly differentiated synovial sarcoma: an analysis of clinical, pathologic, and molecular genetic features. Am J Surg Pathol 1999 Jan;23(1):106-12.

(53) Roth JA, Enzinger FM, Tannenbaum M. Synovial sarcoma of the neck: a followup study of 24 cases. Cancer 1975 Apr;35(4):1243-53.

(54) Rooser B, Willen $H$, Hugoson A, Rydholm A. Prognostic factors in synovial sarcoma. Cancer 1989 Jun 1;63(11):2182-5.

(55) McGrory JE, Pritchard DJ, Arndt CA, Nascimento AG, Remstein ED, Rowland CM. Nonrhabdomyosarcoma soft tissue sarcomas in children. The Mayo Clinic experience. Clin Orthop Relat Res 2000 May;(374):24758. 
(56) de Silva MV, McMahon AD, Paterson L, Reid R. Identification of poorly differentiated synovial sarcoma: a comparison of clinicopathological and cytogenetic features with those of typical synovial sarcoma. Histopathology 2003 Sep;43(3):220-30.

(57) Skytting BT, Bauer HC, Perfekt R, Nilsson G, Larsson O. Ki-67 is strongly prognostic in synovial sarcoma: analysis based on 86 patients from the Scandinavian Sarcoma group register. Br J Cancer 1999 Aug;80(11):180914.

(58) Golouh R, Vuzevski V, Bracko M, van der Heul RO, Cervek J. Synovial sarcoma: a clinicopathological study of 36 cases. J Surg Oncol 1990 Sep;45(1):20-8.

(59) Deshmukh R, Mankin HJ, Singer S. Synovial sarcoma: the importance of size and location for survival. Clin Orthop Relat Res 2004 Feb;(419):15561.

(60) Ferrari A, Casanova M, Massimino M, Luksch R, Cefalo G, Lombardi F, et al. Synovial sarcoma: report of a series of 25 consecutive children from a single institution. Med Pediatr Oncol 1999 Jan;32(1):32-7.

(61) Okcu MF, Munsell M, Treuner J, Mattke A, Pappo A, Cain A, et al. Synovial sarcoma of childhood and adolescence: a multicenter, multivariate analysis of outcome. J Clin Oncol 2003 Apr 15;21(8):1602-11.

(62) Spillane AJ, A'Hern R, Judson IR, Fisher C, Thomas JM. Synovial sarcoma: a clinicopathologic, staging, and prognostic assessment. J Clin Oncol 2000 Nov 15;18(22):3794-803.

(63) Yokoyama K, Shinohara N, Kondo M, Mashima T. Prognostic factors in synovial sarcoma: a clinicopathologic study of 18 cases. Jpn J Clin Oncol 1995 Aug;25(4):131-4.

(64) Campbell C, Gallagher J, Dickinson I. Synovial sarcoma--towards a simplified approach to prognosis. ANZ J Surg 2004 Sep;74(9):727-31.

(65) Chan JA, McMenamin ME, Fletcher CD. Synovial sarcoma in older patients: clinicopathological analysis of 32 cases with emphasis on unusual histological features. Histopathology 2003 Jul;43(1):72-83.

(66) Lopes JM, Bjerkehagen B, Holm R, Bruland O, Sobrinho-Simoes M, Nesland JM. Proliferative activity of synovial sarcoma: an immunohistochemical evaluation of Ki-67 labeling indices of 52 primary and recurrent tumors. Ultrastruct Pathol 1995 Mar;19(2):101-6.

(67) Trassard M, Le D, V, Hacene K, Terrier P, Ranchere D, Guillou L, et al. Prognostic factors in localized primary synovial sarcoma: a multicenter study of 128 adult patients. J Clin Oncol 2001 Jan 15;19(2):525-34.

(68) Nuciforo PG, Pellegrini C, Fasani R, Maggioni M, Coggi G, Parafioriti A, et al. Molecular and immunohistochemical analysis of HER2/neu oncogene in synovial sarcoma. Hum Pathol 2003 Jul;34(7):639-45. 
(69) Broders AC, Hargrave R, Meyerding HV. Pathological features of soft tissue fibrosarcoma with special reference to the grading of its malignancy. Surg Gynecol Obstet 1939;69:267-80.

(70) Baptista AM, de Camargo OP, Croci AT, de Oliveira CR, de Azevedo Neto RS, Giannotti MA, et al. Synovial sarcoma of the extremities: prognostic factors for 20 nonmetastatic cases and a new histologic grading system with prognostic significance. Clinics 2006 Oct;61(5):381-6.

(71) Corson JM, Weiss LM, Banks-Schlegel SP, Pinkus GS. Keratin proteins and carcinoembryonic antigen in synovial sarcomas: an immunohistochemical study of 24 cases. Hum Pathol 1984 Jul;15(7):61521.

(72) Fisher C. The value of electronmicroscopy and immunohistochemistry in the diagnosis of soft tissue sarcomas: a study of 200 cases.

Histopathology 1990 May;16(5):441-54.

(73) Amary MFC, Lancellotti CLP. Graduação Histológica e Imuno-Expressão de Marcadores Epiteliais, Ki-67, p53 e bcl-2 nos Sarcomas Sinoviais Tese apresentada ao curso de Pós-Graduação da Faculdade de Ciências Médicas da Santa Casa de São Paulo para obtenção do título de Mestre em Medicina. 2001.

(74) Machen SK, Fisher C, Gautam RS, Tubbs RR, Goldblum JR. Utility of cytokeratin subsets for distinguishing poorly differentiated synovial sarcoma from peripheral primitive neuroectodermal tumour. Histopathology 1998 Dec;33(6):501-7.

(75) Smith TA, Machen SK, Fisher C, Goldblum JR. Usefulness of cytokeratin subsets for distinguishing monophasic synovial sarcoma from malignant peripheral nerve sheath tumor. Am J Clin Pathol 1999 Nov;112(5):641-8.

(76) Fisher C, Montgomery E, Healy V. Calponin and h-caldesmon expression in synovial sarcoma; the use of calponin in diagnosis. Histopathology 2003 Jun;42(6):588-93.

(77) Kawauchi S, Fukuda T, Oda Y, Saito T, Oga A, Takeshita M, et al. Prognostic significance of apoptosis in synovial sarcoma: correlation with clinicopathologic parameters, cell proliferative activity, and expression of apoptosis-related proteins. Mod Pathol 2000 Jul;13(7):755-65.

(78) Nakanishi H, Ohsawa M, Naka N, Uchida A, Ochi T, Aozasa K. Immunohistochemical detection of bcl-2 and p53 proteins and apoptosis in soft tissue sarcoma: their correlations with prognosis. Oncology 1997 May;54(3):238-44.

(79) Pilotti S, Mezzelani A, Azzarelli A, Rilke F, Pierotti MA. bcl-2 expression in synovial sarcoma. J Pathol 1998 Mar;184(3):337-9.

(80) Hirakawa N, Naka T, Yamamoto I, Fukuda T, Tsuneyoshi M. Overexpression of bcl-2 protein in synovial sarcoma: a comparative study of other soft tissue spindle cell sarcomas and an additional analysis by fluorescence in situ hybridization. Hum Pathol 1996 Oct;27(10):1060-5. 
(81) Suster S, Fisher C, Moran CA. Expression of bcl-2 oncoprotein in benign and malignant spindle cell tumors of soft tissue, skin, serosal surfaces, and gastrointestinal tract. Am J Surg Pathol 1998 Jul;22(7):863-72.

(82) Lopes JM, Nesland JM, Reis-Filho JS, Holm R. Differential Ki67 and bcl-2 immunoexpression in solid-glandular and spindle cell components of biphasic synovial sarcoma: a double immunostaining assessment with cytokeratin and vimentin. Histopathology 2002 May;40(5):464-71.

(83) Miettinen M, Sarlomo-Rikala M, Kovatich AJ. Cell-type- and tumour-typerelated patterns of bcl-2 reactivity in mesenchymal cells and soft tissue tumours. Virchows Arch 1998 Sep;433(3):255-60.

(84) Pelmus M, Guillou L, Hostein I, Sierankowski G, Lussan C, Coindre JM. Monophasic fibrous and poorly differentiated synovial sarcoma: immunohistochemical reassessment of $60 \mathrm{t}(\mathrm{X} ; 18)(\mathrm{SYT}-\mathrm{SSX})$-positive cases. Am J Surg Pathol 2002 Nov;26(11):1434-40.

(85) Konomoto T, Fukuda T, Hayashi K, Kumazawa J, Tsuneyoshi M. Leiomyosarcoma in soft tissue: examination of p53 status and cell proliferating factors in different locations. Hum Pathol 1998 Jan;29(1):7481.

(86) Drobnjak M, Latres E, Pollack D, Karpeh M, Dudas M, Woodruff JM, et al. Prognostic implications of p53 nuclear overexpression and high proliferation index of Ki-67 in adult soft-tissue sarcomas. J Natl Cancer Inst 1994 Apr 6;86(7):549-54.

(87) Kawai A, Noguchi M, Beppu Y, Yokoyama R, Mukai K, Hirohashi S, et al. Nuclear immunoreaction of p53 protein in soft tissue sarcomas. A possible prognostic factor. Cancer 1994 May 15;73(10):2499-505.

(88) Oda Y, Sakamoto A, Satio T, Kawauchi S, Iwamoto Y, Tsuneyoshi M. Molecular abnormalities of p53, MDM2, and H-ras in synovial sarcoma. Mod Pathol 2000 Sep;13(9):994-1004.

(89) Antonescu CR, Leung DH, Dudas M, Ladanyi M, Brennan M, Woodruff JM, et al. Alterations of cell cycle regulators in localized synovial sarcoma: A multifactorial study with prognostic implications. Am J Pathol 2000 Mar;156(3):977-83.

(90) Erlandson RA, Woodruff JM. Role of electron microscopy in the evaluation of soft tissue neoplasms, with emphasis on spindle cell and pleomorphic tumors. Hum Pathol 1998 Dec;29(12):1372-81.

(91) Wei Y, Sun M, Nilsson G, Dwight T, Xie Y, Wang J, et al. Characteristic sequence motifs located at the genomic breakpoints of the translocation $t(X ; 18)$ in synovial sarcomas. Oncogene 2003 Apr 10;22(14):2215-22.

(92) Fletcher CD, Dal CP, De W, I, Mandahl N, Mertens F, Mitelman F, et al. Correlation between clinicopathological features and karyotype in spindle cell sarcomas. A report of 130 cases from the CHAMP study group. Am J Pathol 1999 Jun;154(6):1841-7. 
(93) Limon J, Mrozek K, Nedoszytko B, Babinska M, Jaskiewicz J, Kopacz A, et al. Cytogenetic findings in two synovial sarcomas. Cancer Genet Cytogenet 1989 Apr;38(2):215-22.

(94) Turc-Carel C, Dal CP, Limon J, Li F, Sandberg AA. Translocation X;18 in synovial sarcoma. Cancer Genet Cytogenet 1986 Sep;23(1):93.

(95) Turc-Carel C, Dal CP, Limon J, Rao U, Li FP, Corson JM, et al. Involvement of chromosome $X$ in primary cytogenetic change in human neoplasia: nonrandom translocation in synovial sarcoma. Proc Natl Acad Sci U S A 1987 Apr;84(7):1981-5.

(96) Agus V, Tamborini E, Mezzelani A, Pierotti MA, Pilotti S. Re: A novel fusion gene, SYT-SSX4, in synovial sarcoma. J Natl Cancer Inst 2001 Sep 5;93(17):1347-9.

(97) Amary MFC, Diss TC, Flanagan AM. Molecular characterization of a novel variant of a SYT-SSX1 fusion transcript in synovial sarcoma. Histopathology 2006; In Press.

(98) Brodin B, Haslam K, Yang K, Bartolazzi A, Xie Y, Starborg M, et al. Cloning and characterization of spliced fusion transcript variants of synovial sarcoma: SYT/SSX4, SYT/SSX4v, and SYT/SSX2v. Possible regulatory role of the fusion gene product in wild type SYT expression. Gene 2001 May 2;268(1-2):173-82.

(99) Crew AJ, Clark J, Fisher C, Gill S, Grimer R, Chand A, et al. Fusion of SYT to two genes, SSX1 and SSX2, encoding proteins with homology to the Kruppel-associated box in human synovial sarcoma. EMBO J 1995 May 15;14(10):2333-40.

(100) Fligman I, Lonardo F, Jhanwar SC, Gerald WL, Woodruff J, Ladanyi M. Molecular diagnosis of synovial sarcoma and characterization of a variant SYT-SSX2 fusion transcript. Am J Pathol 1995 Dec;147(6):1592-9.

(101) Mancuso T, Mezzelani A, Riva C, Fabbri A, Dal BL, Sampietro G, et al. Analysis of SYT-SSX fusion transcripts and bcl-2 expression and phosphorylation status in synovial sarcoma. Lab Invest 2000 Jun;80(6):805-13.

(102) Nilsson G, Skytting B, Xie Y, Brodin B, Perfekt R, Mandahl N, et al. The SYT-SSX1 variant of synovial sarcoma is associated with a high rate of tumor cell proliferation and poor clinical outcome. Cancer Res 1999 Jul 1;59(13):3180-4.

(103) O'Sullivan MJ, Humphrey PA, Dehner LP, Pfeifer JD. t(X;18) reverse transcriptase-polymerase chain reaction demonstrating a variant transcript. J Mol Diagn 2002 Aug;4(3):178-80.

(104) Panagopoulos I, Mertens F, Isaksson M, Limon J, Gustafson P, Skytting B, et al. Clinical impact of molecular and cytogenetic findings in synovial sarcoma. Genes Chromosomes Cancer 2001 Aug;31(4):362-72. 
(105) Safar A, Wickert R, Nelson M, Neff JR, Bridge JA. Characterization of a variant SYT-SSX1 synovial sarcoma fusion transcript. Diagn Mol Pathol 1998 Oct; $7(5): 283-7$.

(106) Sanders ME, van de RM, Barr FG. Detection of a variant SYT-SSX1 fusion in a case of predominantly epithelioid synovial sarcoma. Mol Diagn 1999 Mar;4(1):65-70.

(107) Skytting B, Nilsson G, Brodin B, Xie Y, Lundeberg J, Uhlen M, et al. A novel fusion gene, SYT-SSX4, in synovial sarcoma. J Natl Cancer Inst 1999 Jun 2;91(11):974-5.

(108) Sonobe H, Takeuchi T, Liag SB, Taguchi T, Yuri K, Shimizu K, et al. A new human synovial sarcoma cell line, HS-SY-3, with a truncated form of hybrid SYT/SSX1 gene. Int J Cancer 1999 Jul 30;82(3):459-64.

(109) Tornkvist M, Brodin B, Bartolazzi A, Larsson O. A novel type of SYT/SSX fusion: methodological and biological implications. Mod Pathol 2002 Jun;15(6):679-85.

(110) Gure AO, Tureci O, Sahin U, Tsang S, Scanlan MJ, Jager E, et al. SSX: a multigene family with several members transcribed in normal testis and human cancer. Int J Cancer 1997 Sep 17;72(6):965-71.

(111) Gure AO, Wei IJ, Old LJ, Chen YT. The SSX gene family: characterization of 9 complete genes. Int J Cancer 2002 Oct 10;101(5):448-53.

(112) Ladanyi M. Fusions of the SYT and SSX genes in synovial sarcoma. Oncogene 2001 Sep 10;20(40):5755-62.

(113) Iwasaki T, Koibuchi N, Chin WW. Synovial sarcoma translocation (SYT) encodes a nuclear receptor coactivator. Endocrinology 2005 Sep;146(9):3892-9.

(114) Kato H, Tjernberg A, Zhang W, Krutchinsky AN, An W, Takeuchi T, et al. SYT associates with human SNF/SWI complexes and the C-terminal region of its fusion partner SSX1 targets histones. J Biol Chem 2002 Feb 15;277(7):5498-505.

(115) Nagao K, Ito $\mathrm{H}$, Yoshida $\mathrm{H}$. Chromosomal translocation $\mathrm{t}(\mathrm{X} ; 18)$ in human synovial sarcomas analyzed by fluorescence in situ hybridization using paraffin-embedded tissue. Am J Pathol 1996 Feb;148(2):601-9.

(116) Tsuji S, Hisaoka M, Morimitsu Y, Hashimoto H, Shimajiri S, Komiya S, et al. Detection of SYT-SSX fusion transcripts in synovial sarcoma by reverse transcription-polymerase chain reaction using archival paraffin-embedded tissues. Am J Pathol 1998 Dec;153(6):1807-12.

(117) Kawai A, Woodruff J, Healey JH, Brennan MF, Antonescu CR, Ladanyi M. SYT-SSX gene fusion as a determinant of morphology and prognosis in synovial sarcoma. N Engl J Med 1998 Jan 15;338(3):153-60.

(118) Willeke F, Mechtersheimer G, Schwarzbach M, Weitz J, Zimmer D, Lehnert T, et al. Detection of SYT-SSX1/2 fusion transcripts by reverse 
transcriptase-polymerase chain reaction (RT-PCR) is a valuable diagnostic tool in synovial sarcoma. Eur J Cancer 1998 Dec;34(13):2087-93.

(119) Antonescu CR, Kawai A, Leung DH, Lonardo F, Woodruff JM, Healey JH, et al. Strong association of SYT-SSX fusion type and morphologic epithelial differentiation in synovial sarcoma. Diagn Mol Pathol 2000 Mar;9(1):1-8.

(120) Hill DA, Riedley SE, Patel AR, Shurtleff SA, Hyer J, Cain AM, et al. Realtime polymerase chain reaction as an aid for the detection of SYT-SSX1 and SYT-SSX2 transcripts in fresh and archival pediatric synovial sarcoma specimens: report of 25 cases from St. Jude Children's Research Hospital. Pediatr Dev Pathol 2003 Jan;6(1):24-34.

(121) Hiraga H, Nojima T, Abe S, Sawa H, Yamashiro K, Yamawaki S, et al. Diagnosis of synovial sarcoma with the reverse transcriptase-polymerase chain reaction: analyses of 84 soft tissue and bone tumors. Diagn Mol Pathol 1998 Apr;7(2):102-10.

(122) Hostein I, Menard A, Bui BN, Lussan C, Wafflart J, Delattre O, et al. Molecular detection of the synovial sarcoma translocation $t(X ; 18)$ by realtime polymerase chain reaction in paraffin-embedded material. Diagn Mol Pathol 2002 Mar;11(1):16-21.

(123) Jin L, Majerus J, Oliveira A, Inwards CY, Nascimento AG, Burgart LJ, et al. Detection of fusion gene transcripts in fresh-frozen and formalin-fixed paraffin-embedded tissue sections of soft-tissue sarcomas after laser capture microdissection and rt-PCR. Diagn Mol Pathol 2003 Dec;12(4):224-30.

(124) Mezzelani A, Mariani L, Tamborini E, Agus V, Riva C, Lo VS, et al. SYTSSX fusion genes and prognosis in synovial sarcoma. Br J Cancer 2001 Nov 16;85(10):1535-9.

(125) Nikiforova MN, Groen P, Mutema G, Nikiforov YE, Witte D. Detection of SYT-SSX rearrangements in synovial sarcomas by real-time one-step RTPCR. Pediatr Dev Pathol 2005 Mar;8(2):162-7.

(126) Oda Y, Sakamoto A, Saito T, Kinukawa N, Iwamoto Y, Tsuneyoshi M. Expression of hepatocyte growth factor (HGF)/scatter factor and its receptor c-MET correlates with poor prognosis in synovial sarcoma. Hum Pathol 2000 Feb;31(2):185-92.

(127) Shipley J, Crew J, Birdsall S, Gill S, Clark J, Fisher C, et al. Interphase fluorescence in situ hybridization and reverse transcription polymerase chain reaction as a diagnostic aid for synovial sarcoma. Am J Pathol 1996 Feb;148(2):559-67.

(128) Tamborini E, Agus V, Mezzelani A, Riva C, Sozzi G, Azzarelli A, et al. Identification of a novel spliced variant of the SYT gene expressed in normal tissues and in synovial sarcoma. Br J Cancer $2001 \mathrm{Apr}$ 20;84(8):1087-94. 
(129) van de RM, Barr FG, Collins MH, Xiong QB, Fisher C. Absence of SYTSSX fusion products in soft tissue tumors other than synovial sarcoma. Am J Clin Pathol 1999 Jul;112(1):43-9.

(130) Coindre JM, Pelmus M, Hostein I, Lussan C, Bui BN, Guillou L. Should molecular testing be required for diagnosing synovial sarcoma? A prospective study of 204 cases. Cancer 2003 Dec 15;98(12):2700-7.

(131) Ladanyi M, Antonescu CR, Leung DH, Woodruff JM, Kawai A, Healey JH, et al. Impact of SYT-SSX fusion type on the clinical behavior of synovial sarcoma: a multi-institutional retrospective study of 243 patients. Cancer Res 2002 Jan 1;62(1):135-40.

(132) Guillou L, Benhattar J, Bonichon F, Gallagher G, Terrier P, Stauffer E, et al. Histologic grade, but not SYT-SSX fusion type, is an important prognostic factor in patients with synovial sarcoma: a multicenter, retrospective analysis. J Clin Oncol 2004 Oct 15;22(20):4040-50.

(133) Guillou L, Coindre JM, Bonichon F, Nguyen BB, Terrier P, Collin F, et al. Comparative study of the National Cancer Institute and French Federation of Cancer Centers Sarcoma Group grading systems in a population of 410 adult patients with soft tissue sarcoma. J Clin Oncol 1997 Jan;15(1):35062.

(134) Lu YJ, Birdsall S, Summersgill B, Smedley D, Osin P, Fisher C, et al. Dual colour fluorescence in situ hybridization to paraffin-embedded samples to deduce the presence of the $\operatorname{der}(X) t(X ; 18)(p 11.2 ; q 11.2)$ and involvement of either the SSX1 or SSX2 gene: a diagnostic and prognostic aid for synovial sarcoma. J Pathol 1999 Mar;187(4):490-6.

(135) Begueret H, Galateau-Salle F, Guillou L, Chetaille B, Brambilla E, Vignaud $\mathrm{JM}$, et al. Primary intrathoracic synovial sarcoma: a clinicopathologic study of $40 \mathrm{t}(\mathrm{X} ; 18)$-positive cases from the French Sarcoma Group and the Mesopath Group. Am J Surg Pathol 2005 Mar;29(3):339-46.

(136) Bijwaard KE, Fetsch JF, Przygodzki R, Taubenberger JK, Lichy JH. Detection of SYT-SSX fusion transcripts in archival synovial sarcomas by real-time reverse transcriptase-polymerase chain reaction. J Mol Diagn 2002 Feb;4(1):59-64.

(137) Gaffney R, Chakerian A, O'Connell JX, Mathers J, Garner K, Joste N, et al. Novel fluorescent ligase detection reaction and flow cytometric analysis of SYT-SSX fusions in synovial sarcoma. J Mol Diagn 2003 May;5(2):127-35.

(138) Guillou L, Coindre J, Gallagher G, Terrier P, Gebhard S, de Saint Aubain $\mathrm{SN}$, et al. Detection of the synovial sarcoma translocation $t(X ; 18)$ (SYT;SSX) in paraffin-embedded tissues using reverse transcriptasepolymerase chain reaction: a reliable and powerful diagnostic tool for pathologists. A molecular analysis of 221 mesenchymal tumors fixed in different fixatives. Hum Pathol 2001 Jan;32(1):105-12.

(139) Lasota J, Jasinski M, biec-Rychter M, Szadowska A, Limon J, Miettinen M. Detection of the SYT-SSX fusion transcripts in formaldehyde-fixed, paraffin-embedded tissue: a reverse transcription polymerase chain 
reaction amplification assay useful in the diagnosis of synovial sarcoma. Mod Pathol 1998 Jul;11(7):626-33.

(140) Naito N, Kawai A, Ouchida M, Dan'ura T, Morimoto Y, Ozaki T, et al. A reverse transcriptase-polymerase chain reaction assay in the diagnosis of soft tissue sarcomas. Cancer 2000 Nov 1;89(9):1992-8.

(141) Thorson JA, Weigelin HC, Ruiz RE, Howard JK, Lucas DR. Identification of SYT-SSX transcripts from synovial sarcomas using RT-multiplex PCR and capillary electrophoresis. Mod Pathol 2006 May;19(5):641-7.

(142) Tvrdik D, Povysil C, Svatosova J, Dundr P. Molecular diagnosis of synovial sarcoma: RT-PCR detection of SYT-SSX1/2 fusion transcripts in paraffinembedded tissue. Med Sci Monit 2005 Mar;11(3):MT1-MT7.

(143) Wei Y, Wang J, Zhu X, Shi D, Hisaoka M, Hashimoto H. Detection of SYTSSX fusion transcripts in paraffin-embedded tissues of synovial sarcoma by reverse transcription-polymerase chain reaction. Chin Med J (Engl ) 2002 Jul;115(7):1043-7.

(144) Xie Y, Tornkvist M, Aalto Y, Nilsson G, Girnita L, Nagy B, et al. Gene expression profile by blocking the SYT-SSX fusion gene in synovial sarcoma cells. Identification of XRCC4 as a putative SYT-SSX target gene. Oncogene 2003 Oct 23;22(48):7628-31.

(145) Birdsall S, Osin P, Lu YJ, Fisher C, Shipley J. Synovial sarcoma specific translocation associated with both epithelial and spindle cell components. Int J Cancer 1999 Aug 12;82(4):605-8.

(146) Kasai T, Shimajiri S, Hashimoto H. Detection of SYT-SSX fusion transcripts in both epithelial and spindle cell areas of biphasic synovial sarcoma using laser capture microdissection. Mol Pathol 2000 Apr;53(2):107-10.

(147) El-Naggar AK, Ayala AG, bdul-Karim FW, McLemore D, Ballance WW, Garnsey L, et al. Synovial sarcoma. A DNA flow cytometric study. Cancer 1990 May 15;65(10):2295-300.

(148) Kawaguchi S, Wada T, Ida K, Sato Y, Nagoya S, Tsukahara T, et al. Phase I vaccination trial of SYT-SSX junction peptide in patients with disseminated synovial sarcoma. J Transl Med 2005 Jan 12;3(1):1.

(149) O'Sullivan MJ, Kyriakos M, Zhu X, Wick MR, Swanson PE, Dehner LP, et al. Malignant peripheral nerve sheath tumors with $\mathrm{t}(\mathrm{X} ; 18)$. A pathologic and molecular genetic study. Mod Pathol 2000 Dec;13(12):1336-46.

(150) Tamborini E, Agus V, Perrone F, Papini D, Romano R, Pasini B, et al. Lack of SYT-SSX fusion transcripts in malignant peripheral nerve sheath tumors on RT-PCR analysis of 34 archival cases. Lab Invest 2002 May;82(5):60918.

(151) Skytting B. Synovial sarcoma. A Scandinavian Sarcoma Group project. Acta Orthop Scand Suppl 2000 Apr;291:1-28. 
(152) Patel RM, Downs-Kelly E, Weiss SW, Folpe AL, Tubbs RR, Tuthill RJ, et al. Dual-color, break-apart fluorescence in situ hybridization for EWS gene rearrangement distinguishes clear cell sarcoma of soft tissue from malignant melanoma. Mod Pathol 2005 Dec;18(12):1585-90.

(153) Yang K, Lui WO, Xie Y, Zhang A, Skytting B, Mandahl N, et al. Coexistence of SYT-SSX1 and SYT-SSX2 fusions in synovial sarcomas. Oncogene 2002 Jun 13;21(26):4181-90.

(154) Henderson SR, Guiliano D, Presneau N, McLean S, Frow R, Vujovic S, et al. A molecular map of mesenchymal tumors. Genome Biol 2005;6(9):R76.

(155) Nagayama S, Katagiri T, Tsunoda T, Hosaka T, Nakashima Y, Araki N, et al. Genome-wide analysis of gene expression in synovial sarcomas using a cDNA microarray. Cancer Res 2002 Oct 15;62(20):5859-66.

(156) dos Santos NR, de Bruijn DR, van Kessel AG. Molecular mechanisms underlying human synovial sarcoma development. Genes Chromosomes Cancer 2001 Jan;30(1):1-14.

(157) Amary MF, Berisha F, Bernardi FC, Herbert A, James M, Reis-Filho JS, et al. Detection of SS18-SSX fusion transcripts in formalin-fixed paraffinembedded neoplasms: analysis of conventional RT-PCR, qRT-PCR and dual color FISH as diagnostic tools for synovial sarcoma. Mod Pathol 2007 Apr;20(4):482-96.

(158) Vang R, Biddle DA, Harrison WR, Heck K, Cooley LD. Malignant peripheral nerve sheath tumor with a $\mathrm{t}(\mathrm{X} ; 18)$. Arch Pathol Lab Med 2000 Jun;124(6):864-7. 


\section{Apêndices}

Trabalhos publicados 